I NTER NATIONAL MONETARY FUND

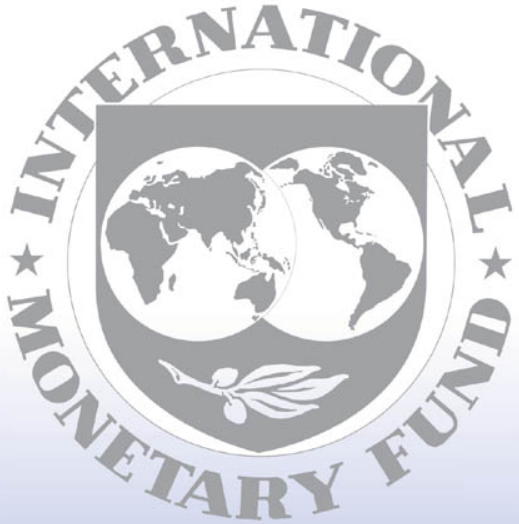

Staff

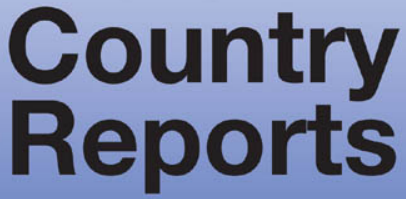




\title{
Sierra Leone: 2004 Article IV Consultation, the Fifth Review Under the Poverty Reduction and Growth Facility, and Requests for Waiver of Performance Criteria and Extension of Arrangement-Staff Report; Staff Statement; Public Information Notice and Press Release on the Executive Board Discussion; and Statement by the Executive Director for Sierra Leone
}

Under Article IV of the IMF's Articles of Agreement, the IMF holds bilateral discussions with members, usually every year. In the context of a combined discussion of the 2004 Article IV consultation with Sierra Leone, the fifth review under the Poverty Reduction and Growth Facility, and requests for waiver of performance criteria and extension of arrangement, the following documents have been released and are included in this package:

- $\quad$ the staff report for the combined 2004 Article IV consultation, the fifth review under the Poverty Reduction and Growth Facility, and requests for waiver of performance criteria and extension of arrangement, prepared by a staff team of the IMF, following discussions that ended on October 5, 2004, with the officials of Sierra Leone on economic developments and policies. Based on information available at the time of these discussions, the staff report was completed on October 28, 2004. The views expressed in the staff report are those of the staff team and do not necessarily reflect the views of the Executive Board of the IMF.

- $\quad$ a staff statement of November 12, 2004 updating information on recent economic developments.

- a Public Information Notice (PIN) and Press Release, summarizing the views of the Executive Board as expressed during its November 12, 2004, discussion of the staff report on issues related to the Article IV consultation and the IMF arrangement, respectively. a statement by the Executive Director of Sierra Leone.

The documents listed below have been or will be separately released.

Letter of Intent sent to the IMF by the authorities of Sierra Leone*

Memorandum of Economic and Financial Policies by the authorities of Sierra Leone*

Selected Issues Paper and Statistical Appendix

Technical Memorandum of Understanding*

*May also be included in Staff Report

The policy of publication of staff reports and other documents allows for the deletion of market-sensitive information.

To assist the IMF in evaluating the publication policy, reader comments are invited and may be sent by e-mail to publicationpolicy@imf.org.

\author{
Copies of this report are available to the public from \\ International Monetary Fund • Publication Services \\ $70019^{\text {th }}$ Street, N.W. $\bullet$ Washington, D.C. 20431 \\ Telephone: (202) 623-7430 • Telefax: (202) 623-7201 \\ E-mail: publications@imf.org•Internet: http://www.imf.org \\ Price: $\$ 15.00$ a copy \\ International Monetary Fund \\ Washington, D.C.
}


This page intentionally left blank

CInternational Monetary Fund. Not for Redistribution 


\title{
SIERRA LEONE
}

\section{Staff Report for the 2004 Article IV Consultation, the Fifth Review Under the Poverty Reduction and Growth Facility, and Requests for Waiver of Performance Criteria and Extension of Arrangement}

\author{
Prepared by the African Department \\ (In consultation with the External Relations, Finance, Fiscal Affairs, Legal, Monetary \\ and Financial Systems, Policy Development and Review, and Statistics Departments) \\ Approved by Siddharth Tiwari and Anthony R. Boote
}

October 28, 2004

- Sierra Leone is on a 24 month consultation cycle. The last Article IV consultation with Sierra Leone was concluded in March 2002. At the time, Executive Directors emphasized that the authorities needed to strengthen fiscal discipline and expedite the pace of structural reforms.

- Sierra Leone has a three-year PRGF arrangement with the Fund, which was approved on September 26, 2001 in an amount of SDR 130.84 million (126 percent of quota). The fourth review under the PRGF arrangement was completed on February 23, 2004 (www.imf.org, Country report No. 04/49). Executive Directors endorsed the macroeconomic objectives of the program for 2004, and underscored the need to solidify economic gains and maintain peace, and to develop a realistic and ambitious medium-term framework to guide economic policy-making. Directors also suggested that enough resources be allocated to the preparation of a full Poverty Reduction Strategy Paper (PRSP). In the context of the review, the program was extended to March 26, 2005, and the test date for the fifth review under the program was rephased from endDecember 2003 to end-March 2004. The completion of the fifth review will entitle Sierra Leone to a disbursement of SDR 14 million.

- Discussions on the 2004 Article IV consultation and the fifth review under the three-year Poverty Reduction and Growth Facility (PRGF) arrangement took place in Freetown during June 22-July 5, 2004. Further discussions on Article IV issues were held during October 2-5, 2004, when the authorities were in Washington to attend the Annual Meetings. The staff team comprised Messrs. Rwegasira (head), Kovanen, and Köhler (all AFR), Mr. Gottschalk (PDR), and Mr. Gulati (Administrative Assistant-AFR). The mission met with the Minister of Finance, Mr. Joseph B. Dauda, the Minister of Presidential Affairs, Dr. Sheku Sesay, the Minister of Education, Science, and Technology, Dr. Alpha T. Wurie, the Minister of Agriculture and Food Security, Dr. Sama Sahr Monde, the Deputy Defence Minister, Mr. Joe C. Blell, the Minister of Energy and Power, Mr. Emmanuel Grant, the Deputy Governor of the Bank of Sierra Leone, Mr. Fofana, other senior government officials, as well as representatives of the private sector and the donor community. 


\section{Contents}

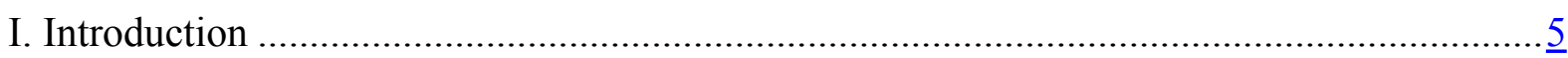

II. Overview of Key Issues and Medium-Term Challenges .......................................... $\underline{5}$

III. Recent Developments and Performance Under the Program ........................................ $\underline{6}$

A. Recent Economic Developments ..............................................................

B. Performance Under the Program at end-March 2004 ......................................... $\underline{9}$

IV. Report on the Discussions ............................................................................ 11

A. Key Challenges and Medium-Term Economic Strategy ....................................11

B. Macroeconomic Objectives and Policies for the Remainder of 2004 ..................... $\frac{19}{20}$

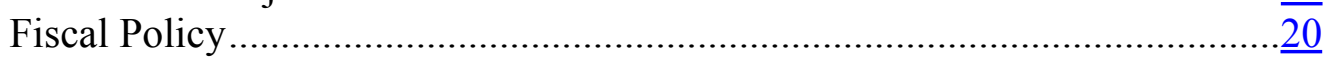

Monetary and Financial Sector Policies ............................................... $\frac{22}{25}$

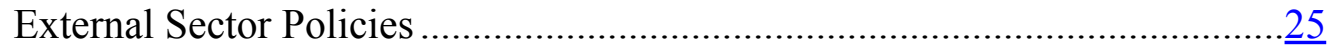

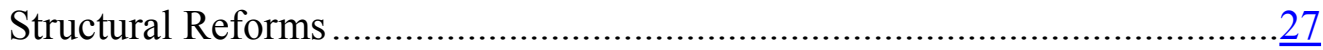

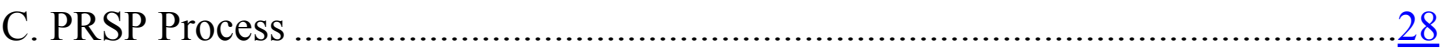

D. Technical Assistance and Statistics...........................................................

V. Program Monitoring and Reviews ................................................................... 29

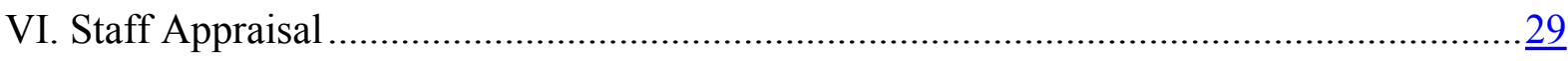

Tables

1. Selected Economic and Financial Indicators, 2001-05 …............................................38

2. Central Government Financial Operations, 2001-07 …...........................................39

3. Monetary Survey, December 2001-December 2005 …............................................... $\frac{41}{42}$

4. Balance of Payments, 2001-07 ............................................................................. $\frac{42}{43}$

5. Selected Economic and Financial Indicators, 2004-09 .......................................... $\frac{43}{44}$

6. Status of HIPC Initiative Completion Point Triggers................................................. 44

7. External Financing Requirements and Sources, 2002-09 ….....................................

8. Disbursements Under the PRGF Arrangement, 2001-05 …......................................46

9. Indicators of Capacity to Repay the Fund, 1999-2009 ................................................ $\frac{47}{48}$

10. Poverty-Related Expenditure by Activity, 2000-04 ................................................ $\frac{48}{49}$

11. Selected Social and Demographic Indicators ....................................................

Figures

1. Trends in Interest Rate, Exchange Rate, and Consumer Price Index (CPI), January 2000-June 2004 ............................................................................... $\frac{32}{33}$

2. Balance of Payments, 2004-04 …........................................................................ $\frac{33}{34}$

3. Nominal and Real Effective Exchange Rates, January 2000-June 2004 ........................ $\frac{34}{35}$

4. Official and Parallel Exchange Rates, January 200-June 2004 ................................... $\frac{35}{36}$

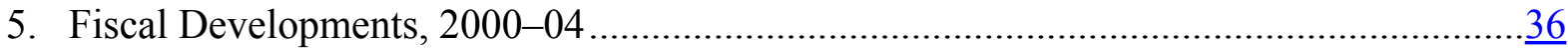

6. Monetary Developments, 2001-04 ..................................................................... 
Boxes

1. Structural Conditionality.............................................................................

2. Large-Scale Mining-Challenges and the Way Forward ..............................................16

3. Progress in Achieving Millennium Development Goals (1990-2015)...........................18

4. Financial Soundness Indicators of the Banking System ..........................................23

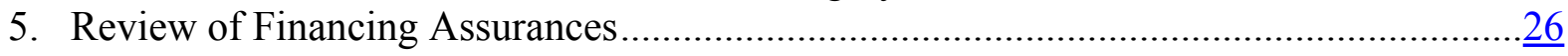

Appendices

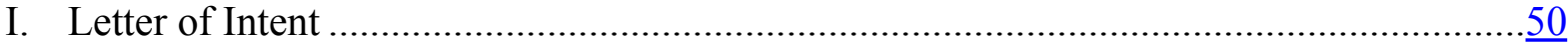

Attachment I. Memorandum of Economic and Financial Policies of the Government of Sierra Leone for April 1-December 31, 2004 ...............................52

Table 1. Quantitative Performance Criteria and Indicative Targets Under the PRGF Arrangement (January-December 2003) ...........................................62

Table 2. Proposed Quantitative Performance Criteria and Indicative Targets Under the PRGF Arrangement, (January-December 2004) ............................................63

Table 3. Structural Performance Criteria and Benchmarks for September 2003December 2004 Under the Program Supported by the PRGF Arrangement.

Table 4. Structural Performance Criteria and Benchmarks for July-December 2004 Under the Program Supported by the PRGF Arrangement ................................. $\frac{65}{66}$

Attachment II. Technical Memorandum of Understanding ...................................... $\underline{66}$

II. Relations with the Fund .................................................................................

III. Relations with the World Bank Group..............................................................

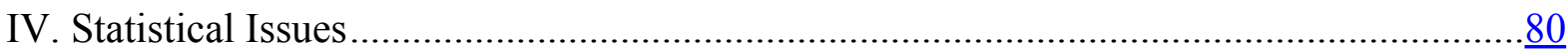

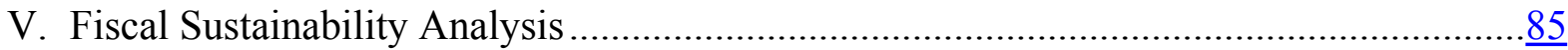

Table 1. Public Sector Debt Sustainability Framework, Baseline Scenario, 2001-22.

Figure 1. Indicators of Public Debt Under Alternative Scenarios, 2003-22 …............. $\frac{88}{89}$

Figure 2. Indicators of Public Debt Under Alternative Scenarios, 2003-22 ..................

VI. External Debt Sustainability Analysis ....................................................................

Table 1a. External Debt Sustainability Framework, Baseline Scenario, 2000-23

Table 1b. Sensitivity Analyses for Key Indicators of Public and Publicly

Guaranteed External Debt, 2003-23.

Figure 1. Indicators of Public and Publicly Guaranteed External Debt Under

Alternative Scenarios, 2001-21 


\section{Executive Summary}

- $\quad$ The economy enjoyed a robust recovery in 2003 , but inflation accelerated. Real growth reflected robust activity in agriculture, mining, manufacturing, and services.

- Growth prospects in the medium term are encouraging, largely based on some mining projects coming to fruition, agricultural expansion, and service-related activities. Real growth is projected in the range of between 6-7 percent in 2005-07 (with higher growth in 2005 led by mineral exports), reflecting these activities in the country's post-conflict phase. Inflation is expected to revert to low single digits, while the current account deficits would narrow, aided by growth in mineral exports. The projected strong growth will, however, still leave Sierra Leone, the lowest ranking country on UNDP's index of Human Development Indicators, far short of the MDGs.

- $\quad$ Performance as at end-March 2004 under the PRGF arrangement was mixed. While progress was made in implementing program structural measures, fiscal and monetary policies were weaker than envisaged. Shortfalls in external program support in the first quarter of 2004 were not adequately compensated for by fiscal tightening. The government has taken steps to bring year-end domestic financing of the budget closer to program targets.

- During the remainder of 2004, macroeconomic policies will need to focus on bringing inflation down for the year as a whole while supporting a continued high level of activity. Domestic expenditures should be tailored closely to projected domestic revenues and external budgetary support, while protecting poverty-related spending. Non-interest current spending should be reduced below the program level. The overall fiscal deficit (including grants) is projected to rise above the 2003 level, while the domestic primary deficit should narrow by a large margin. The domestic financing of the budget should be contained to about $1 \frac{1}{2}$ percent of GDP, which is above the program level of nearly 1 percent, because of large domestic borrowing (reflecting delays in external assistance) and high interest rates.

- Monetary policy in 2004 should complement fiscal policy to reduce inflation. To assist in containing money growth and mopping up excess liquidity, the Bank of Sierra Leone intends shortly to raise the statutory reserve requirement ratio. Reserve money is projected to grow at $6 \frac{1}{2}$ percent in 2004 .

- With respect to structural reforms, the reconciliation of fiscal and monetary data, is to be undertaken with Fund technical assistance, in October 2004. The issuance of new personnel management regulations will constitute a prior action to be completed before Board consideration of the fifth review under the PRGF arrangement. The rest of structural reforms for the remainder of the year aim at reinforcing the budgetary process and its transparency; enhancing civil service reforms; and further strengthening the management of the school system. 


\section{INTRODUCTION}

1. Discussions on the $\mathbf{2 0 0 4}$ Article IV consultation and the fifth review under the three-year Poverty Reduction and Growth Facility (PRGF) arrangement took place in Freetown during June 22-July 5, 2004. The Article IV discussions focused on the mediumterm strategy, including the policies needed to support key growth and poverty reduction objectives. The discussions on the fifth review concentrated on recent economic developments and macroeconomic policies for the remainder of 2004. The completion of the 2004 Article IV consultation discussions was delayed beyond the required 24-month consultation cycle owing to delays in completing the fourth and fifth reviews of the PRGF arrangement. Staff had to await confirmation of EU program support for Sierra Leone before finalization of discussions and program papers for the fifth review.

2. The 2001 Article IV consultations with Sierra Leone was concluded in March 2002. At the time, Directors emphasized the need to strengthen fiscal discipline and expedite the pace of structural reforms to enhance budget implementation and service delivery, streamline tax administration, and improve the efficiency of the tax system. Directors also urged the authorities to expedite civil service reforms and the privatization of public enterprises. They noted Sierra Leone's weak statistical base and the need to strengthen capacity in that area.

\section{Further progress was made in $\mathbf{2 0 0 3}$ towards completing Sierra Leone's post-} conflict transition. The government concluded the disarmament, demobilization, and reintegration (DDR) exercise for over 72,000 former combatants in February 2004. In light of the need to provide additional time for the government to train and equip its police and military forces, the United Nations have decided to maintain a reduced presence in Sierra Leone at least until mid-2005 (originally the UNAMSIL forces were to be withdrawn by end2004). Security in neighboring Liberia has improved and will enhance stability in Sierra Leone.

\section{OVERVIEW OF KEY ISSUES AND MEDIUM-TERM CHALLENGES}

4. As a post-conflict country, Sierra Leone's development needs are immense. Institutions and infrastructure were damaged during the protracted civil war of the $1990 \mathrm{~s}$, and economic confidence declined together with domestic savings investment. With the onset of peace since 2000 , the authorities have been pursuing prudent macroeconomic policies and implementing wide-ranging structural reforms. In contrast to a cumulative decline of 22 percent in real GDP between 1996-2000, output has expanded rapidly in 2001-03 (Table 1), reflecting the resettlement of population and increased activities in agriculture, mining, manufacturing, and services. Inflation has on the whole remained moderate, but risen to double digits more recently due to a combination of higher fuel costs, expansionary monetary policy, and a depreciation of the currency.

\section{The authorities' overall medium-term strategy for sustaining high growth and} reducing poverty focuses on six key areas: continued strengthening of state security to assure investors and other economic agents; aiming at a more sustainable fiscal position that 
is key to maintaining macroeconomic stability; raising savings and investment necessary for sustained high growth; strengthening of infrastructure to integrate the economy and reduce transaction costs; agricultural and rural development to foster pro-poor growth; and the promotion of the private sector to spearhead the development of productive activities.

\section{Considerable resources and strong policies will be needed to advance the} strategy. The authorities should aim at reaching the country's full tax potential, including through tapping mineral revenues. Expenditures would need to be better prioritized, in the context of a PRSP, and gradually reoriented to finance investment. Better coordination with donors will also be important for efficient fiscal management and the mobilization of increased resources for poverty reduction programs. With respect to private sector resources, the main policy challenges are the enhancement of the investment climate, the strengthening of governance and transparency, and the development of the financial sector.

\section{Recent Developments And Performance Under the Program}

\section{A. Recent Economic Developments}

\section{The economy enjoyed a robust recovery in 2001-03, but inflation accelerated in} 2003 (Table 1). ${ }^{1}$ Strong output growth in 2001-03 reflects robust operations in agriculture, mining, and manufacturing. ${ }^{2}$ The rise in prices in 2003 resulted initially from higher fuel costs but expansionary monetary policy and a depreciation of the currency towards the end of the year also fueled inflation. Annual average inflation at end-June 2004 reached 12 percent.

Sierra Leone: Real GDP and Inflation, 2001-2003

\begin{tabular}{lrrrrr}
\hline & 2001 & 2002 & \multicolumn{2}{c}{2003} \\
\cline { 4 - 6 } \cline { 4 - 6 } Real GDP & Act. & Est. & Prog. & Est. \\
\hline Consumer prices (annual average) & & (Annual & percentage change) \\
& 17.9 & 27.5 & 6.5 & 9.3 \\
\hline
\end{tabular}

8. Fiscal performance in $\mathbf{2 0 0 3}$ was somewhat weaker than envisioned, largely due to domestic expenditure overruns (Table 2). Domestic revenue collection was stronger and

\footnotetext{
${ }^{1}$ See Selected Issues and Statistical Appendix, 10/29/04 (www.imf.org) for further elaboration on macroeconomic trends during 2002-03.

${ }^{2}$ Gross domestic product has been revised upwards beginning with 2001, with STA technical assistance. This in part reflects the post-conflict recovery and the extension of coverage to the service sector and related informal activities. As a result, real growth rates during 2001-03 period have been revised from 5.4, 6.3, and 6.5 percent for these years, respectively, to $17.9,27.5$, and 9.3 percent. The increases in coverage of national accounts are not directly reflected in higher reported growth figures.
} 
current expenditures were lower than programmed. External program support, at 5.5 percent of GDP in the original program, only materialized at slightly over 3 percent of GDP. ${ }^{3}$ This led to much larger than programmed domestic financing of the budget, especially from the banking system. Project grants and loans were also below the program levels by a wide margin, while poverty-related outlays exceeded the program target.

Sierra Leone: Fiscal Performance, 2001-Q1 2004

\begin{tabular}{|c|c|c|c|c|c|c|}
\hline & \multirow{2}{*}{$\begin{array}{r}2001 \\
\text { Act. }\end{array}$} & \multirow{2}{*}{$\begin{array}{r}2002 \\
\text { Act. }\end{array}$} & \multicolumn{2}{|c|}{2003} & \multicolumn{2}{|c|}{ Q1 2004} \\
\hline & & & Prog. & Act. & Prog. & Act. \\
\hline & \multicolumn{6}{|c|}{ (In percent of GDP) } \\
\hline Government domestic revenue & 13.0 & 12.1 & 12.2 & 12.4 & 2.9 & 2.8 \\
\hline Total expenditure and net lending & 29.5 & 28.6 & 33.3 & 26.9 & 7.2 & 7.1 \\
\hline Of which: current expenditure & 24.8 & 24.2 & 22.8 & 22.1 & 5.3 & 5.1 \\
\hline \multicolumn{7}{|l|}{ Overall fiscal balance } \\
\hline (commitment basis, including grants) & -10.6 & -8.3 & -7.9 & -6.7 & -0.9 & -2.0 \\
\hline (commitment basis, excluding grants) & -16.5 & -16.5 & -21.1 & -14.5 & -4.3 & -4.3 \\
\hline Domestic primary fiscal balance & -7.7 & -7.0 & -5.5 & -5.6 & -1.6 & -0.9 \\
\hline Program grants and loans & 4.2 & 8.0 & 5.5 & 3.3 & 2.7 & 0.0 \\
\hline Project grants and loans & 5.1 & 4.9 & 10.8 & 3.9 & 1.6 & 2.1 \\
\hline Domestic financing & 3.2 & 0.9 & 2.3 & 4.3 & -0.8 & 0.9 \\
\hline
\end{tabular}

9. Fiscal pressures continued in the first quarter of 2004. Although the government scaled down its outlays, this was insufficient in light of the large shortfall in external nonHIPC grants and program loans. ${ }^{4}$ Project grants and loans materialized slightly above the program levels. Larger than programmed fiscal expenditures, notably as a result of higher domestic interest outlays, resulted in a significant rise in domestic financing of the budget, particularly from the banking system. Noninterest current expenditures were below the programmed level, including social and poverty-related outlays (the disbursements were slowed down by new procurement procedures). ${ }^{5}$

\footnotetext{
${ }^{3}$ HIPC grants are excluded from external program support (see the Technical Memorandum of Understanding).

${ }^{4}$ The shortfalls occurred because of delays in completing an audit that constituted part of EU grant conditionality and due to administrative delays with the disbursement of the AfDB loan.

${ }^{5}$ For example, a government audit of the Ministry of Health and the ongoing procurement reform have slowed goods and services outlays. Some catch-up in spending is likely in the second quarter.
} 
10. Monetary policy in $\mathbf{2 0 0 3}$ was loose, as it accommodated the expansionary fiscal policy (Table 3). The Bank of Sierra Leone (BSL) also allowed private sector credit to continue growing at a fast pace. The rapid build up of domestic public debt since late 2003, resulting from the large domestic financing of the budget, led to sharply higher nominal Treasury bill rates (Figure 1). Broad and reserve money growth rates were higher than programmed for the year as a whole.

Sierra Leone: Financial Sector Indicators, 2001-Q1 2004

\begin{tabular}{|c|c|c|c|c|c|c|}
\hline & \multirow{2}{*}{$\begin{array}{c}2001 \\
\text { Act. }\end{array}$} & \multirow{2}{*}{$\begin{array}{r}2002 \\
\text { Act. }\end{array}$} & \multicolumn{2}{|c|}{2003} & \multicolumn{2}{|c|}{ Q1 2004} \\
\hline & & & Prog. & Act. & Prog. & Act. \\
\hline \multicolumn{7}{|c|}{ (Annual percentage change, unless otherwise indicated) } \\
\hline Broad money & 33.7 & 30.1 & 12.1 & 23.9 & 20.2 & 25.9 \\
\hline Domestic credit & 6.9 & 3.0 & 3.0 & 12.1 & 0.7 & 12.3 \\
\hline Government & 6.2 & 0.1 & 2.9 & 7.7 & -1.6 & 7.6 \\
\hline Private sector & 24.6 & 62.3 & 19.8 & 64.5 & 23.0 & 64.1 \\
\hline Reserve money & 29.4 & 24.9 & 11.3 & 22.4 & 26.7 & 27.3 \\
\hline Velocity (level) & 5.5 & 5.2 & $\ldots$ & 5.0 & $\ldots$ & $\ldots$ \\
\hline Treasury bill interest rate (end of period); in percent. & 14.7 & 15.0 & $\ldots$ & 20.2 & $\ldots$ & 26.5 \\
\hline
\end{tabular}

\section{The external current account weakened further in $\mathbf{2 0 0 3}$ compared to the $\mathbf{2 0 0 2}$} outcome (Table 4). While export performance during the year improved, particularly for diamonds, imports remained high due to continued expansion in reconstruction activities and the higher cost of fuel. Gross official reserves fell to 1.5 months of imports, well below the program level. The real effective exchange rate depreciated by 17 percent in 2003 (Figure 2), partly reflecting the high foreign-exchange demand to finance private sector imports.

Sierra Leone: External Sector Performance, 2001-2003

\begin{tabular}{lrrrr}
\hline & 2001 & 2002 & \multicolumn{2}{c}{2003} \\
\cline { 4 - 6 } & Act. & Est. & Prog. & Proj. \\
\hline & \multicolumn{4}{c}{ (Annual percentage change) } \\
Exports (U.S. dollars) & 6.1 & 48.9 & 8.7 & 27.4 \\
Imports (U.S. dollars) & 20.6 & 54.4 & 34.3 & 15.6 \\
& & (In percent of GDP) & \\
Current account balance & & & & \\
$\quad$ (including official transfers) & -17.4 & -4.8 & -15.2 & -7.6 \\
$\quad$ (excluding official transfers) & -22.0 & -12.1 & -33.6 & -14.1 \\
Gross international reserves & & & & \\
$\quad$ (in months of imports) & 1.9 & 2.5 & 2.2 & 1.5 \\
\hline
\end{tabular}

12. The government missed a number of indicative performance targets at end-2003 (Appendix I, Table 1). Owing to fiscal slippages and the delays in external budget support during 2003, the government missed at end-December the indicative ceilings on net domestic bank credit to the government, net domestic assets of the BSL, and the government's wage 
bill, and the floor on domestic primary budget balance. All other indicative program targets were met, including the floors on government domestic revenues and poverty-related outlays.

\section{B. Performance Under the Program at end-March 2004}

\section{Performance under the program was mixed during the first quarter of this year} (Appendix I, Table 2). All quantitative performance criteria at end-March 2004 were met, except for the ceiling on net bank credit to the government, which was exceeded by Le 13.3 billion (equivalent of 6 percent of reserve money), after adjusting for the shortfall in external program support and for the issuance of treasury bills to the nonbank private sector. ${ }^{6}$ The adjustment in government outlays was inadequate in light of the non-disbursement of nonHIPC program financing (totaling 2.9 percent of GDP), related to the African Development Bank (AfDB) loan (US\$14.5 million received in April 2004), and the European Union grant (programmed at $€ 12$ million).

\section{There was uneven progress in implementing program structural measures} in 2004 (Appendix I, Table 3). Two structural performance criteria subject to the fifth review under the program were met: one pertaining to the issuance of identification cards for the remaining 20 percent of all verified teachers, and the other, to the issuance of guidelines requiring double signatures in operating school bank accounts. However, the structural performance criterion on the reconciliation of fiscal and monetary data for 2000-02 was not completed by the end-May 2004 deadline, as the provision of Fund technical assistance was not forthcoming as projected (now taking place in October; para. 51) due to unforeseen staff constraints in STA. Moreover, new personnel management regulations for the civil service were not introduced by end-May 2004 as envisaged, pending the finalization of a new employment scheme for senior civil servants (the senior executive service); this measure is to be implemented as a prior action for completion of the fifth review. Progress has been made in completing the structural benchmarks under the program (see Box 1).

\footnotetext{
${ }^{6}$ Under the program the government was expected to adjust spending to compensate for half of the shortfall (corresponding to about 1.5 percent of GDP).

${ }^{7}$ For details, see section II of the Memorandum of Economic and Financial Policies.
} 


\section{Box 1. Sierra Leone: Structural Conditionality}

\section{Coverage of structural conditionality under the PRGF arrangement}

The structural conditionality under the current program (Table 4 of Appendix I) will focus on strengthening budgetary discipline and transparency, and advancing civil service reforms. For the sixth review, there will be one performance criterion related to the reconciliation of fiscal and monetary data for earlier program years; this will be completed by end-November 2004, following the provision of technical assistance from the Fund. With regard to structural benchmarks, two new measures have been included in the program: the government will take steps to ensure that by end-2004 at least 60 percent of teachers are paid through school bank accounts; and employment ceilings for individual schools will be published in the government gazette at the beginning of each school year.

\section{Status of structural conditionality}

During the period October 2003 - June 2004 (see Table 2 of Appendix I), further progress was achieved in implementing structural performance criteria and benchmarks. The structural performance criterion related to the reconciliation of fiscal and monetary data was not observed due to a delay in the provision of advice from the Fund. The structural performance criterion related to the issuance of new personnel management regulations for the civil service was not completed; it awaited the incorporation of the proposed new structure for senior civil servants. This measure is a prior action for the fifth review under the PRGF arrangement, to be completed by mid-October 2004. Progress regarding the implementation of the program structural benchmarks was uneven.

\section{Structural areas covered by World Bank lending conditionality}

Under the World Bank's Economic Rehabilitation and Recovery Credit (ERRC) and the Institutional Reform and Capacity Building Project (IRCBP), reforms are being implemented, comprising the creation of a plan for the divesture of public enterprises, the enactment of an acceptable investment code, the enactment of local government legislation, the strengthening of the financial management system, the development of a program for procurement reform, including enacting a new legislation and regulatory framework, the completion of an impact study on the Common External Tariff, the establishment of a cadastre for mining rights, and the piloting of mining sector extension services (Appendix III).

Status of areas covered by the HIPC Initiative floating completion point

Sierra Leone has made further progress toward meeting the HIPC Initiative completion point triggers, notably related to disarmament and demobilization, decentralization of government functions, education, and health. First draft of the full PRSP was circulated for comments to all stakeholders in August 2004.The PRSP document is expected to be completed by end-December 2004. The government needs to implement the full PRSP for at least a year before the country could reach the HIPC Completion Point, which would be earliest at end-2005. Table 6 provides an update on the status of implementation of the triggers. 


\section{REPORT ON THE DISCUSSIONS}

15. The discussions with the authorities focused on the medium-term strategy, including the policies needed to support key growth and poverty reduction objectives, as well as on the review of program implementation up to March 2004, updating the macroeconomic framework and reaching understanding on macroeconomic policies for the second half of 2004, and establishing quantitative and structural performance criteria and benchmarks through December 2004.

\section{A. Key Challenges and Medium-Term Economic Strategy}

16. The authorities acknowledged the critical importance of sustaining high real growth and a stable macroeconomic environment for tackling Sierra Leone's widespread poverty. ${ }^{\mathbf{8}}$ The medium-term macroeconomic framework projects annual growth in the range of 6-7 percent. Rising exports will continue to support high output growth in 2004-06, with higher growth in 2005 led by mineral exports. Apart from mining, activities related to agriculture, forestry and fishing as well as services are expected to remain vibrant in the medium term, in part reflecting the favorable post-conflict environment. Inflation is projected to revert to low single digits by the end of the period (Table 5). The current account balance (excluding official transfers) is expected to narrow to 10 percent of GDP by 2007.

\section{The continued strengthening of state security is seen as vital for underpinning} economic confidence. The authorities stressed that more time was needed to assure investors and other economic agents that Sierra Leone was moving firmly to a post-conflict phase. The planned reduced presence of UNAMSIL forces, though implying increased security costs for the country, was seen as a right step in confidence building, demonstrating that the country could rely on itself to secure peace within its borders. The staff recognized the importance of this issue and underscored the need to prioritize expenditures within limited budgetary resources, placing due emphasis on poverty-reducing spending.

\section{The government's medium-term fiscal strategy aims at achieving a more} sustainable fiscal position in order to address the emerging domestic debt problem. The authorities recognize that in the medium-term, the overall resource envelope would remain constrained. On the one hand, external budgetary resources (as a percent of GDP) are projected to gradually decline as the country's post-conflict support and HIPC grants taper off; however, additional resources not currently projected could become available in the context of the PRSP and financing for the MDGs. On the other hand, the introduction of the Common External Tariff (CET) of the ECOWAS is expected to lead to a small reduction in customs revenues (as a share of GDP). The staff, therefore, encouraged the authorities to continue strengthening tax administration and effecting related measures aimed at enhancing

\footnotetext{
${ }^{8}$ The 2004 Human Development Report of the United Nations Development Program lists Sierra Leone as the last country in terms of human development indexes.
} 
domestic revenue collection. Furthermore, the authorities agreed that the tax base needs to be expanded to tap mineral revenues (the staff estimated that additional revenue between 1-2 percent of GDP annually could be expected from customs duties, royalties, and income and other taxes due to rising mineral production and exports), to cover other activities not currently taxed, and to gradually include the informal sector. They also agreed that the scope of income and corporate tax rate reductions (proposed but not effected in the 2004 budget) should be reconsidered in light of the overall resource envelope.

19. In furtherance of privatization, the authorities indicated that with technical assistance, sales of public assets (e.g., in ports, marketing boards, banks, and the national airline), could raise additional fiscal revenues to finance poverty-related programs or to lower the domestic debt stock. This is in line the authorities' earlier efforts to privatize state enterprises and will be pursued as part of the medium-term strategy.

20. On the expenditure side, the staff projects current expenditures to gradually fall in the medium-term, from 22 percent of GDP in 2003 to $181 / 2$ percent in 2007 . In light of this, better prioritization, rationalization, and cost-cutting is needed to allow the government to meet its developmental and poverty-related objectives (in the contexts of the PRSP).

Furthermore, expenditure would need to be gradually reoriented away from consumption and wages to investment (in light of sizeable infrastructure needs), to support economic growth. More efficient service deliveries will also be necessary both at central and local government levels.

21. In response to repeated lower-than-projected outcomes of external budgetary support, the authorities need to strengthen mechanisms for monitoring the implementation of donor conditions to expedite disbursements. While the budget needs to reflect planned receipts of external assistance, the authorities should plan their expenditures cautiously so that the bulk of expenditures do not take place until the assistance is actually received.

\section{The Sierra Leonean authorities concurred with staff that fiscal sustainability} requires that the government progressively move toward a broadly balanced primary position (Appendix V). ${ }^{9}$ The authorities indicated that the budget for 2005 would be framed in a medium-term context. Improved fiscal positions would lead to gradually declining debtto-GDP and debt-to-revenue ratios, and would assist in lowering the domestic debt stock and domestic interest costs. Strong macroeconomic policies would be essential for fiscal sustainability, as a negative output shock could lead to rapidly rising debt-to-GDP and debtto-revenue ratios; this remains a risk to the medium-term fiscal outlook. Fiscal sustainability would be assisted by debt relief in the context of the HIPC Initiative.

\footnotetext{
${ }^{9}$ Chapter II of the Special Issues and Statistical Appendix, 10/29/04 (www.imf.org) provides further details on this topic.
} 
Sierra Leone: Fiscal Sustainability (in percent of GDP)

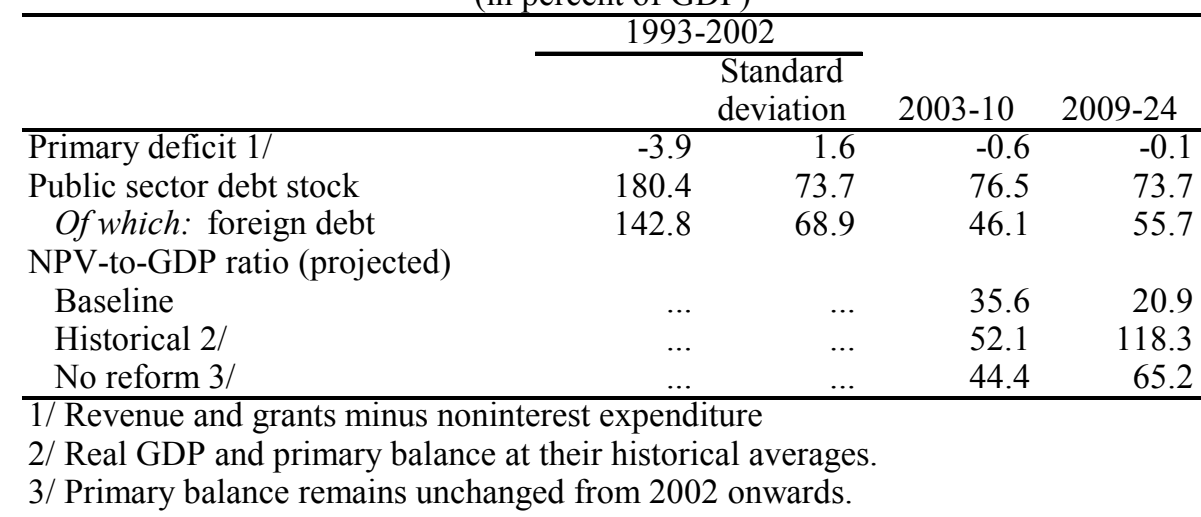

23. The updated external debt sustainability analysis points to a moderate risk of debt distress (Appendix VI). In the medium-term, higher new borrowing projections in the baseline scenario lead to a more graduated decline in the NPV of debt-to-exports ratio, which is projected to level-off at about 140 percent beginning in 2010. The debt service ratio is projected to remain below 10 percent for most of the projection horizon. Even though the baseline debt dynamics do not give rise to concern, substantial vulnerabilities emerge when the baseline is subjected to stress testing.

\section{Sustained high growth in Sierra Leone will require substantial increases in} domestic savings and investment. The authorities believe that with institutional and policy measures together with enhanced economic confidence, private sector savings would be boosted. The staff welcomed the authorities' efforts in assisting the growth of community and microfinance institutions, and the commitment to maintain financial liberalization, including market-determined interest rates. The government also plans to contribute to this broad endeavor through budgetary savings. With these measures, the objective in the medium-term is to substantially improve the domestic savings rate to a range of 8-10 percent by 2006-07, from below 2 percent in 2004. Although this is an ambitious objective, staff considers it attainable as it merely restores Sierra Leone's historical average in the mid1980s, while remaining at about half of the average level for sub-Saharain Africa. On the investment side, the investment rate has risen significantly, led by private investment in large scale mining projects. Gross domestic investment is projected at 18.4 percent in 2004 compared to an average of about 12 percent of GDP in 2000-03. In the subsequent years, the investment rate is projected to decline somewhat with the completion of the mining projects, but the policy objective is to raise the medium-term rate significantly above the 2000-03 performance (para. 28). Public sector investment has depended largely on external donor financing, which is likely to continue given the country's substantial infrastructure and other development related needs. The government intends to progressively raise the share of domestically financed investment expenditure, in part by directing the projected expanded mineral revenues to this purpose.

\section{The post-conflict situation in Sierra Leone will continue to demand substantial strengthening of infrastructure to remedy past dislocations and reduce transaction}


costs. The authorities pointed especially to the importance of rural roads for improved agricultural marketing and social service delivery, and of water and sanitation for improved health. They also underlined the role of energy supply, especially electricity, for productive and consumer uses in various sectors, including small- and medium-scale enterprises. In this regard, the authorities plan to mobilize concessional resources to complete the Bumbuna hydroelectric power project, and to attract private investors, notably from South Africa, to develop other sources of electricity. The staff encouraged the authorities to attract private investors in the provision of electricity and other utilities.

\section{Agriculture and rural development will be crucial for broad-based growth and}

poverty reduction. The share of the agricultural sector is projected to rise from 37 percent of GDP in 2002-03 to about 40 percent in 2006-07. The authorities indicted that a key policy goal is to achieve food security by 2007 , particularly with respect to domestic rice production. For this purpose, the government is embarking on a multi-pillar approach (in the context of its poverty reduction strategy) to raise agricultural output and productivity, promote large-scale commercial farming, and encourage crop diversification. The authorities recognize the importance of capacity building (research, education, and training in farming techniques), improved infrastructure, and support and extension services. ${ }^{10}$ The government is also reviewing land legislation to develop an enabling environment for land utilization. ${ }^{11}$ The staff considered the government's plan as ambitious, though achievable, and underscored that in order to strengthen the overall approach and possibly attract donor support in these areas, the government should sharpen the key elements of its policy for the agricultural sector.

27. In order to support rural development, the authorities are embarking on decentralizing government administration and the delivery of services. In May 2004, local elections were conducted. The local governments will be vested with the responsibility of providing core public services and implementing the PRSP. Institutional strengthening and capacity building will be vital in these efforts, and they are being supported by an IDA grant of US\$6 million. These efforts are also key to the government's program of enhancing governance. The authorities stressed that decentralization would be pursued strictly within anticipated budgetary resources. There would be a transition phase of four years during which the delivery of core services by local governments would be supported by corresponding transfers from central government. Capital expenditures during this phase would also be supported by the IDA grant. In the subsequent period, local government expenditures would

\footnotetext{
${ }^{10}$ Given the low income levels, the government is looking into microfinance and machine leases through the banking system as a way to make equipments more broadly available to farmers.

${ }^{11}$ In the Western area, land is owned by freehold, while in other parts of the country land is communal.
} 
be supported by local taxes and other revenues, as well as predetermined transfers from the central government.

28. Private sector development and the improvement of the investment climate are a vital pillar to support Sierra Leone's continued growth. While the public sector will take a lead in strengthening infrastructure and improving public service delivery, the authorities emphasized the role of the private sector in spearheading the development of productive activities in most sectors. The strengthening of the investment climate to attract domestic and foreign investment, especially in mineral development, and the development of the financial sector are seen as major challenges in that effort. The mining sector, with a share of slightly less than 10 percent of GDP in 2002-03, has considerable export potential and the sector's share in GDP is expected to increase to about 13 percent in 2006-07. Significant revenues are also expected from mining activities. The adoption of the new Core Mining Policy, which will establish a comprehensive framework for the mining sector, the implementation of a new investment code, with World Bank assistance, and participation in the EITI would be important steps in attracting private sector investment while safeguarding the fiscal revenue potential of the sector (Box 2). ${ }^{12}$

29. Greater progress is needed in strengthening governance and transparency to further improve the investment climate and safeguard the use of public resources. The authorities outlined the progress made so far in fighting corruption, specifically through the work of the Anti-Corruption Commission. They stressed that corruption in Sierra Leone is an old problem inherited from past administrations and that the efforts required to stem it should not be underestimated. Twelve corruption related convictions had been made, some involving high officials, while 30-40 corruption cases were pending. The support to the Commission, provided by DfID, was welcomed because the hiring of local lawyers was difficult at public sector salaries, although current Commission employees were among the highest paid public officials. The authorities also indicated that a national strategic committee which includes representatives of donors and civil society had been formed to reinvigorate the anticorruption drive. The staff welcomed the formation of the committee and stressed the importance of demonstrating local ownership and political commitment at the highest levels of government.

\footnotetext{
${ }^{12}$ Sierra Leone ratified in May 2004 the agreement on the certification of the origin of diamond exports (the Kimberley Process). Furthermore, it has expressed an interest to participate in the EITI.
} 


\section{Box 2. Sierra Leone: Large-Scale Mining - Challenges and the Way Forward}

Sierra Leone has considerable potential for large-scale mining. Prior to the war, the Sierra Rutile mine, for example, produced over 25 percent of the world's output. ${ }^{1}$ The country has also two known kimberlite diamond deposits and a bauxite deposit. The war in the 1990s, however, led to the closure of large-scale mining operations.

Facilitating the restart of large-scale mining operations poses a difficult challenge for the government in that it has to balance the demand for suitable incentives with the need for preserving the tax revenue potential of the sector. The existing general fiscal regime provides a good starting point in that it imposes only a moderate tax burden and is reasonably free of targeted incentives. The recently formulated Core Mineral Policy, which lays out the government's objective for this sector, confirms commitment to an investor friendly, progressive and predictable tax regime with well defined parameters. A review of existing legislation and the development of operational regulations will be concluded in 2005 with the assistance of DfID.

A main challenge has been in the application of these ideas in practice, since on each occasion in the past that an investor has applied for a mining lease, that investor had also sought and received a special agreement incorporating specific fiscal terms for the project. Moving forward, it will be important to ensure that such special agreements, if granted, do not undermine the general fiscal framework. To limit discretionary tax incentives, any fiscal provisions in these agreements should be restricted to crossreferencing the relevant fiscal legislation.

The second challenge relates to the enhancement of transparency in this sector. More transparency on revenue flows from mineral extraction could go a long way towards addressing wide-spread governance concerns. The government has taken a step in this direction by expressing its interest to the World Bank in participating in the Extractive Industries Transparency Initiative (EITI). ${ }^{2}$ The World Bank is also assisting the government to establish a modern mineral rights and cadastre (land registry) for the mining industry.

${ }^{1}$ Rutile is a mineral that consists of titanium dioxide with little iron.

${ }^{2}$ The basic principle of the EITI requires the government to publish its receipts of mineral resource revenues and the mineral companies to report their payments to the government. Any differences should be reconciled in a clear and consistent manner. 
30. The authorities intend to maintain a floating exchange rate regime. A floating exchange rate regime since the beginning of the 1990s allowed flexibility in response to external and internal shocks, such as the sharp increase in domestic inflation in this period that did not result in a sharp appreciation of the real effective exchange rate. ${ }^{13}$ Moreover, the parallel market spread has remained low and broadly stable since the end of the civil strive in 2000 (Figure 4). Therefore, the staff considers a floating exchange rate appropriate for Sierra Leone, given the open economy and the need to maintain a competitive external position. The envisaged strengthening of the external current account position, led by strong export expansion, could result in an appreciation of the real exchange rate over the medium-term. Furthermore, the BSL plans to increase its reserves to provide a cushion against external shocks. The exchange system will remain free from restrictions on the making of payments and transfers for current international transactions.

31. The medium-term objective of trade policy is the adoption of the CET as part of the consolidation of the ECOWAS integration process. ${ }^{14}$ The adoption of the CET tariff structure is projected to lead to a reduction in the simple average tariff from $171 / 2$ percent to about 12 percent. Furthermore, joining the ECOWAS CET would allow Sierra Leone to benefit from the envisaged Economic Partnership Agreement with the EU. Sierra Leone does not impose significant non-trade barriers, has no export taxes, and does not face significant export barriers in developed countries.

32. Beyond the medium-term, available social indicators for Sierra Leone show the very low level of human development and the pressing need for moving toward the MDGs (Box 3). ${ }^{15}$ Comparing the indicators to their 1989/90 benchmarks, Sierra Leone has made little headway in reducing poverty during the past decade, by and large, as a result of the prolonged civil conflict. ${ }^{16} \mathrm{~A}$ full assessment of the current situation is, however, hampered by the inadequacy of data (required to establish reliable trends). ${ }^{17}$ On this issue, the government has set up a technical working group comprising staff from various ministries.

13 For comparison, the rise in inflation in mid-1980s combined with nominal exchange rate rigidity resulted in a significant real effective exchange rate appreciation.

${ }^{14}$ Changes to the trade regime since the last Article IV discussions have been minor.

${ }^{15}$ The 2004 Human Development Report of the United Nations Development Programs lists Sierra Leone as the last country in terms of human development indexes.

${ }^{16}$ Given methodological and technical differences in the computation of consumption poverty, it is difficult to compare the 2003/04 survey results with the 1989/90 results.

${ }^{17}$ Data in Sierra Leone is at best unreliable and there are significant gaps in the data. 


\section{Box 3. Sierra Leone: Progress in Achieving Millennium Development Goals (1990-2015)}

Sierra Leone, still recovering from the aftermath of the devastating civil conflict, ranks last in terms of life expectancy, education attainment, child and maternal mortality rates, and income per capita in the 2004 UNDP Human Development Index.

Owing to the economic, social and physical destruction caused by the decade-long civil conflict that ended in January 2002, the country finds itself deeply impoverished, with the result that the current status of most Millennium Development Goals (MDGs), and other socio-economic indicators, have deteriorated from their base year (1990) position. With a GDP per capita of US\$121 in 2002, the proportion of people living in extreme poverty (with expenditures of less than US\$1 per day) has increased from 57 percent in 1990 to an estimated 89 percent by 2002. Life expectancy at birth was only 34.3 years in 2002 compared to the average of 46.3 years for sub-Saharan Africa. The 2002 child mortality rate of 284 per 1000 and the maternal mortality of 2000 per 100,000 live birth are the highest in the world.

The status for other MDGs, such as reducing the proportion of people suffering from extreme hunger, increasing access to safe drinking water, and combating the spread of communicable diseases and HIV/AIDS is also disappointing. Gender inequality persists, though data is still unavailable on the issue. Sierra Leone will therefore have to make huge strides in the years ahead in order to come close to achieving the MDGs by 2015 . The completion of the full PRSP by 2004 and its implementation over the medium term is expected to contribute significantly in the fight against the abject poverty and in monitoring progress towards the attainment of MDGs.

\begin{tabular}{|lccc|}
\hline & \multicolumn{3}{c}{ Status of Achievement } \\
MDG & (in \% unless otherwise indicated) \\
\hline 1) Population living in extreme poverty & $\underline{\mathbf{1 9 9 0}}$ & $\underline{\mathbf{2 0 0 0}}$ & $\underline{\mathbf{2 0 1 5}}$ \\
$\begin{array}{l}\text { 2) Universal primary education (net primary school } \\
\text { enrolment for school-age children) }\end{array}$ & 57.0 & 89.0 & 28.5 \\
$\begin{array}{l}\text { 3) Proportion of children under five-years that are } \\
\text { underweight }\end{array}$ & 52.0 & 42.0 & 100 \\
$\begin{array}{l}\text { 4) Proportion of population without access to } \\
\text { safe drinking water }\end{array}$ & 24.0 & 27.0 & 12.0 \\
5) Proportion of children under one-year immunized against measles & 79.0 & 60.0 & 100 \\
6) Infant mortality rate per 1,000 live birth & 35.0 & 57.0 & 17.5 \\
7) Maternal mortality ratio per 100,000 live birth & 302 & 284 & 100 \\
8) HIV prevalence rate among adults 15-49 years & 700 & 2,000 & 175 \\
\hline
\end{tabular}

Sources: World Development Indicators database, April 2004; UNDP; and Sierra Leonean authorities. 
33. The emerging findings from the 2003/04 household survey suggest that in rural and urban areas outside Freetown the incidence of poverty remains high. The national average poverty rate is about 70 percent, using the national poverty line of Le 2,111 per day (this is about 1 U.S. dollar per day) to cover food and nonfood basic needs.

34. No independent estimate has been made to assess the resource requirements, but it is clear that substantial external resources would be needed to make a leap towards meeting the MDGs. Additional resources would need to be mobilized to ensure adequate funding for public programs (including those outlined in Box 3) that are key to meeting the stated human development goals by 2015 or within any other indicated time-frame. The authorities expressed confidence that with the impending finalization of the full PRSP, they would be able to focus better on the various poverty reduction goals with policies and available resources. Appropriate policy frameworks would also need to be put in place to safeguard macroeconomic stability in case of large increases in aid.

\section{B. Macroeconomic Objectives and Policies for the Remainder of 2004}

35. The macroeconomic framework for 2004 was updated in light of recent developments and revised outlook for the second half of the year. For 2004, staff projects real output to grow 7.4 percent, slightly higher than under the program. ${ }^{18}$ The key drivers of growth would be agriculture, manufacturing, construction, and service industries. Inflation has been significantly above the programmed level (in June the year-on-year inflation stood at 15 percent), and staff projects year-end inflation at 13 percent. The revised outlook reflects a continuation of inflationary pressures coming from the fiscal and external sides, although the program aims at reducing the pressures through fiscal and monetary tightening. The current account deficit (excluding official transfers) is projected at about 18 percent of GDP, 4 percentage points above the 2003 level, with large import needs for the rehabilitation of the mining sector offsetting strong export growth. ${ }^{19}$

\footnotetext{
${ }^{18}$ This reflects the broadening of the data coverage under the revised national accounts.

${ }^{19}$ Previous estimates projected a current account deficit excluding grants of around 30 percent. The downward revision is due to changes in the compilation of the balance of payments and national accounts data. The former led to significantly higher estimates of private transfers and the latter to a substantial upward revision in Sierra Leone's gross domestic product.
} 
Sierra Leone: Real Sector Indicators, 2004

\begin{tabular}{|c|c|c|}
\hline & \multicolumn{2}{|c|}{2004} \\
\hline & Prog. & Rev.Prog. \\
\hline & \multicolumn{2}{|c|}{ (Annual percentage change) $1 /$} \\
\hline Real GDP & 6.8 & 7.4 \\
\hline Consumer prices (period average) & 4.8 & 13.6 \\
\hline $\begin{array}{l}\text { Current account balance } \\
\text { (excluding official transfers; percent of GDP) }\end{array}$ & -31.3 & -17.7 \\
\hline
\end{tabular}

$1 /$ Unless otherwise indicated.

\section{Fiscal Policy}

36. Fiscal adjustment in the second half will aim at bringing domestic expenditures closer to projected resources. A particular issue concerns domestic interest outlays, which were significantly above the program level in the first half of the year and are projected to remain well above in the second half as well. In order to contain the rise in overall spending, the authorities agreed to reduce noninterest current outlays in the second half of the year. Poverty-related expenditures would be protected as much as possible (they are programmed to increase slightly from the previous year's level), but would fall short of the original program target. Reflecting this tightening, together with the projected pick up in external program support (see next para.), the overall fiscal balance (including grants) and domestic primary balance would improve significantly in the second half of the year. As a result, domestic financing of the budget is programmed to decline during this period, which should assist in easing pressure on the Treasury bill interest rates. ${ }^{20}$

Sierra Leone: Fiscal Indicators, 2004

\begin{tabular}{|c|c|c|c|c|}
\hline & Jan.- & & Jul & \\
\hline & Prog. & Act. & Prog. & Prog. \\
\hline (In perce & & & & \\
\hline Government domestic revenue & 5.8 & 6.1 & 5.9 & 6.1 \\
\hline Total expenditure and net lending & 13.6 & 14.7 & 12.8 & 14.1 \\
\hline Of which: current noninterest expenditure & 8.1 & 7.7 & 7.2 & 6.8 \\
\hline Of which: interest expenditure & 1.8 & 2.4 & 1.9 & 3.0 \\
\hline Overall fiscal balance & & & & \\
\hline (commitment basis, including grants) & -2.5 & -5.3 & -3.0 & -2.2 \\
\hline (commitment basis, excluding grants) & -7.8 & -8.5 & -6.9 & -8.1 \\
\hline Domestic primary fiscal balance & -2.9 & -1.8 & -1.9 & -1.1 \\
\hline Program grants and loans & 3.3 & 1.4 & 2.2 & 4.6 \\
\hline Domestic financing & 0.3 & 2.0 & 0.6 & -0.5 \\
\hline
\end{tabular}

${ }^{20}$ The rapid rise of nominal interest rates reflects in part inflation expectations and the shallowness of the Treasury bill market in Sierra Leone. 
37. In respect of external budgetary support for the second half of 2004, the staff awaited confirmation of the EU disbursement before finalizing the fiscal program for the remainder of the year. ${ }^{21}$ The staff have confirmed the expected inflows from DfID and the World Bank for the last quarter of 2004.

\section{To further improve revenue prospects the authorities should better target fiscal incentives while limiting the discretionary granting of tax exemptions to foreign} investors. The staff suggested that tax incentives should not take the form of tax holidays, as these have proven ineffective in attracting foreign investments in many countries, but rather be linked directly to the amount of investment. In addition, the Mines and Minerals Act should not include fiscal provisions (tax schedules for the mineral sectors should be part of the relevant fiscal legislation). The NRA intends to develop model agreements for the mineral sector, since similar agreements for the petroleum sector proved useful.

39. On the expenditure side, further prioritization of expenditures affecting the rest of 2004 has been made, to align expenditures better with available resources. Noninterest expenditures were reduced by $2 \frac{1}{2}$ percent of GDP for the year as a whole, compared to the original program. The domestic interest bill is projected to increase by almost two percent of GDP relative to the original program in part due to significantly higher domestic borrowing costs and financing than earlier envisioned. ${ }^{22}$

40. Government ministries should avoid the accumulation of utility arrears. Progress has been made with regard the National Power Agency (NPA) where the arrears that resurfaced in late 2003 were cleared (through a cross debt liability arrangement and the payment of the net debt totaling Le 6.4 billion due from government). It also appears that the current billing arrangement with the ministries works reasonably well. However, the billing arrangements for electricity and water services (provided by Sierratel and the Guma Valley water company) resulted in the accumulation of arrears during 2002-03. A payment plan to clear the amounts due from government is yet to be agreed. The problems are partly due to inefficient expenditure controls ${ }^{23}$ and weak billing practices as well as insufficient budgetary allocations.

\footnotetext{
${ }^{21}$ About one-half of current expenditure are financed by donors. As noted earlier, in the first quarter of 2004 no external non-HIPC budgetary support (programmed at Le 76 billion or about 3 percent of GDP) was received.

${ }^{22}$ The Treasury bill interest rate reached 27 percent in May 2004, compared to 15 percent in October 2003. Interest rate on the government's ways and means account balance with the central bank has been set at 20 percent per annum.

${ }^{23}$ For example, the introduction of cellular phones led to a huge increase in the phone bill.
} 
41. The civil service reform is ongoing. ${ }^{24}$ An important issue relates to the pay scale for the envisaged executive service, recommended by a Presidential commission. The goal is to establish a core group of highly trained and experienced senior executives, with pay linked to performance. The staff emphasized that this would need to be implemented within a predictable resource envelope. Decentralization of key government functions will have significant impact on the civil service.

\section{Monetary and financial sector policies}

42. In light of the recent inflationary pressures, the discussions centered around the need to maintain an appropriately tight monetary policy. While recognizing the challenge to monetary policy emanating from the fiscal side, the staff expressed concern over the rapid expansion of commercial bank credit, particularly to the private sector that grew by 81 percent from June 2003 to June 2004. The growth was led by lending to commerce and finance, manufacturing, construction, and service sectors. In this context, staff underscored delinquency risks that could arise from the fast-paced expansion of banks' balance sheets and the need for banks to be adequately supervised and well capitalized (Box 4).

\section{Reserve money will continue to be the primary intermediate monetary policy} target. Reserve money growth is projected to increase by $6 \frac{1}{2}$ percent in the second half of 2004, after remaining broadly constant in the first half. The rise in reserve money reflects in part higher statutory reserve requirement ratio (next para.) and increasing demand for currency. The planned reduction in government borrowing from the banking system in the second half of the year will be consistent with the reserve money target. The BSL will rely on its net domestic asset as the principal instrument to achieve its stated monetary policy objective of price stability. ${ }^{25}$ In this context, the authorities noted that they have introduced regular meetings between BSL and senior officials in the Ministry of Finance to enhance monetary and fiscal policy coordination.

\footnotetext{
${ }^{24}$ Further discussion on civil service reforms is provided in the section on structural reforms. ${ }^{25}$ Annual Report 2003 of the BSL.
} 


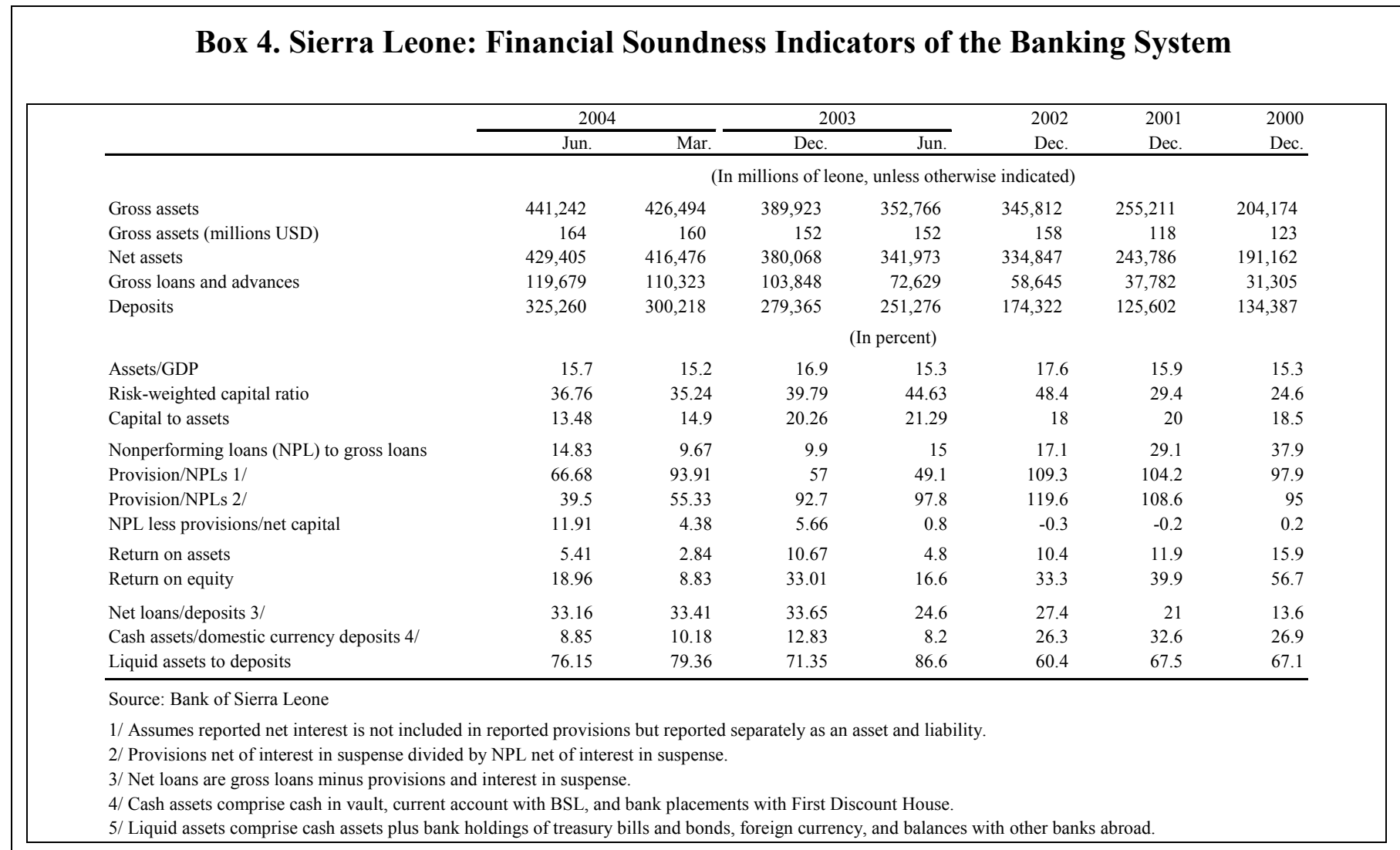

Key points:

- $\quad$ Banking system assets have grown rapidly during December 2000-03. This has been fueled, on the liability side, by a rapid growth of banking system deposits.

- $\quad$ On a risk-weighted basis, banks' capitalization has improved to 40 percent in 2003 compared to 25 percent in 2000. Reported capitalization figures reflect the high level of government securities in banks' balance sheets. During 2004 the risk-weighted capital ratio has declined somewhat due to an increase in nonperforming loans (NPLs).

- $\quad$ The NPLs have fallen substantially since 2000. The decline reflects, for the most part, improvements in corporations' financial position and their ability to repay debts. However, in light of the rapid increase in credits to the private sector in recent years caution is warranted when interpreting these figures.

- $\quad$ In an environment of rapidly expanding banking activities and high real interest rates the commercial banks have been able to sustain a high level of profitability, as measured by return to equity. 
44. The BSL will implement several measures with the view of enhancing its liquidity management. First, the authorities are in the process of raising the statutory reserve ratio, which covers only banks' local currency deposits. On reserve requirements for banks' foreign currency deposits, the BSL has requested technical assistance from the Fund to guide the authorities on best-practices and experiences with such requirements in other countries. Second, BSL also intends to modify the liquid-asset requirements by including in it a cash reserve ratio of 12 percent. ${ }^{26}$ This measure, accompanied by the increase in reserve

requirements, should constrain banks' reserves to provide loans, causing a decline in deposits and hence in money supply (by about 1 percentage point). Third, by end-October 2004 the BSL plans to start secondary market (repurchase) operations in government securities to strengthen its liquidity management. ${ }^{27}$ For this purpose, establishing an electronic book-entry system for government securities and the framework for forecasting liquidity may need to be supported by further technical assistance from MFD.

45. The exchange rate will continue to be based on BSL's weekly foreign exchange auctions. At end-2003, the authorities closed the special window for providing foreign exchange to oil companies. International reserves are programmed to rise from 1.5 months of import cover at end-2003 to two months of imports by end-2004.

46. The BSL has made further progress in strengthening its internal and external controls. For the 2003 audit, the BSL has already contracted Parnell Kerr Forsters, with head office in London, to sign off the report prepared with a local firm. Furthermore, additional staff has been hired in the BSL's Audit Department, including a qualified department head. The computerization of the central bank's record-keeping is under way (funded in part by the World Bank), and will strengthen internal controls. The BSL needs to take additional steps towards implementation of International Financial Reporting Standards as progress has been limited so far.

47. Fund technical assistance to the BSL continue to focus on monetary operations, banking supervision, and payment systems. Additional assistance is expected on developing primary and secondary market operations and liquidity forecasting of the BSL.

\footnotetext{
${ }^{26}$ The liquid-asset ratio will remain at 40 percent for demand deposits and 20 percent for time and savings deposits, comprising cash in tills and vaults, placements with the First Discount House, holdings in treasury bills, and holdings of treasury bearer bonds maturing within 91 days.

${ }^{27}$ Repurchase operations are already taking place between commercial banks and the First Discount House.
} 


\section{External sector policies}

\section{The current account deficit should begin to narrow in $\mathbf{2 0 0 5}$, after reaching its}

peak in 2004. The current account deficit is projected to reach 18 percent of GDP in 2004 . Exports are projected to remain buoyant this year, benefiting from the resumption of rutile production, while imports would remain high owing to the continued high demand for reconstruction-related imports and the increased cost of fuel. Next year, export growth will remain strong. While the growing economy would sustain a high demand for imports, mining-related imports are expected to moderate. However, foreign exchange inflows on account of emergency relief and UNAMSIL operations are projected to decline, thus reducing appreciation pressure on the exchange rate.

49. The Bank of Sierra Leone has adopted the Fifth Edition of the Balance of Payments Manual and completed the compilation of the balance of payments for 2002. As a result, the current account balance including public transfers has improved by about US\$35 million in 2002 relative to previous estimates. ${ }^{28}$ This work has benefited from technical assistance from STA, and entailed the development of new survey instruments.

50. Significant progress has been achieved in preparing a comprehensive mineral policy framework (Box 2). ${ }^{29}$ In the interim, until the revisions to the legislative framework have been finalized, the authorities intend to consult with Fund staff in the context of the PRGF-supported program, as had been envisaged earlier (prior to any future commitments to be made in this area). ${ }^{30}$

51. Debt relief agreements with most official creditors have been reached, but there is little progress with commercial creditors. Debt relief agreements on Naples terms have been signed with all Paris Club creditors except Japan, and seven out of eleven agreements

\footnotetext{
${ }^{28}$ The revision has led to better measurement of non-dutiable imports, and a very significant upward revision in private transfers to non governmental organizations, which had not been previously captured. Some items previously recorded as public transfers have also been reclassified as private transfers, which contributed to a significant downward revision in the current account deficit excluding public transfers.

${ }^{29}$ Complementing these efforts in the non-mineral sector, the authorities intend to enact in the near future an investment code, which has been reviewed by the World Bank.

${ }^{30}$ The authorities consider last year's decision to accept equity in a rutile mining project as a one-off situation. The authorities intend to work towards ensuring that the terms of last year's agreement would not apply to any further mining leases of this company. The authorities, however, do not object to offer of "free" equity, which is equivalent to a profit tax in the sense that it allows the authorities to share in the upside benefits of projects, but does not involve any financial obligations nor management involvement for the authorities.
} 
on Cologne terms have been signed. ${ }^{31}$ Significant reduction in the NPV of debt to exports is however expected after Sierra Leone reaches the HIPC completion point. All non-Paris Club official creditors have agreed to deliver debt relief, or indicated their willingness to do so, even though the terms in some cases fall short of what is expected under the HIPC Initiative. The authorities have also requested the World Bank for a debt buyback operation under the IDA facility in order to continue addressing the problem of commercial debt arrears (Box 5).

\section{Box 5. Sierra Leone: Review of Financing Assurances}

The staff considers that in light of the steps the authorities have taken to collaborate approach with private commercial creditors, they have met the good-faith criterion established under the Fund's policy for lending into arrears.

The authorities have continued their efforts to reach agreements with commercial creditors holding debt eligible for, but not included in, a 1995 World Bank-sponsored buyback. The outstanding commercial debt can be broadly classified into three categories:

- debt that was not validated at the time of the 1995 debt buyback, mostly because of late submissions;

- debt that was validated but where creditors chose not to participate in the debt buyback operation;

- $\quad$ and debt that was incurred after 1995, mostly owed to military suppliers.

Most of Sierra Leone's commercial creditors have remained passive in recent years, but some creditors, in particular those with claims in the second and third debt categories, have pressed their claims aggressively, including using litigation. The authorities have engaged these creditors repeatedly, and have made good-will payments of small amounts to several of them. However, they have failed to reach debt rescheduling agreements that would be comparable to recently signed Paris Club agreements and consistent with the HIPC Initiative.

To move the situation forward, the authorities decided to request a second debt-buyback to be supported by the recently replenished debt-reduction facility of the World Bank (for IDA-only countries). Such a debt buyback would be priced on the total outstanding obligations including late interest and penalty, with prices always set below the NPV equivalent of the full provision of traditional Paris Club and HIPC relief.

The accumulation of arrears to commercial creditors has not undermined program implementation, since no new financing from commercial sources was anticipated.

\footnotetext{
${ }^{31}$ Draft agreements for most of the outstanding cases have been prepared. Finalizing these agreements has been delayed because negotiations were often conducted via correspondence, which proved time consuming.
} 


\section{Structural reforms}

52. The reconciliation of fiscal and monetary data for the period $2000-02$ will be a structural performance criterion for end-November 2004. This would benefit from STA technical assistance in October. ${ }^{32}$

\section{Further action is required to channel salary and other payments to teachers via}

bank accounts. While the guidelines for the opening of school bank accounts were issued earlier this year, the opening of these bank accounts has been slow at end-June school bank accounts were only opened for about 30 percent of the schools). The government will aim at raising the proportion of schools with bank accounts to 60 percent at end-December 2004, which will be a structural benchmark for the sixth review under the program. Furthermore, the government will encourage greater use of banking services for salary payments to civil servants and teachers through individual bank accounts.

54. The government is enhancing the effectiveness of public service deliveries. The introduction of new personnel management regulations for the civil service, establishing a code of ethics, an appraisal system, and a performance-based system, will be a prior action for the fifth review. The government is also in the process of streamlining major ministries to assist in the efficient staffing of the ministries. Diagnostics studies and reforms for six key ministries would be finalized by 2005, and for the remaining ministries by end-2006. The DfID is provided funding for these studies.

55. Budgetary processes are being strengthened. The government would present to Parliament, by end-October, the Budgetary and Accountability Act, aimed at streamlining the budgetary process. In liaison with the World Bank, the government has also prepared interim regulations to guide procurements until the new procurement act has been finalized (expected by early next year); the authorities are in the process of establishing a permanent tender board. ${ }^{33}$ In addition, there will be continuous structural benchmarks aimed at establishing and publishing employment ceilings for all individual schools in the beginning of each school year, and at updating monthly the database of civil servants and teachers. This information would be used to update the payroll data base of the Accountant General's Office.

56. On securitizing the remaining stock of domestic arrears, the authorities have not yet completed this structural benchmark. In order to bring this issue to a closure, the government has examined various options and decided to pay smaller creditors in cash. For the remaining amount of about Le 20 billion, which is owed to a single creditor and which is still subject to legal and administrative disputes, the government was to communicate its final stand to the claimant by end-September 2004 .

${ }^{32}$ Following reconciliation, the BSL will need to provide to the Fund revised program data for all test dates.

${ }^{33}$ The interim procurement regulations were approved by Cabinet in June 2004. 


\section{PRSP Process}

57. The authorities have completed the first draft of the full PRSP. They had indicated that a full PRSP report would not be ready by mid-2004, as envisioned at the conclusion of the fourth review, but would be completed in the coming months. The authorities have undertaken the exercise in broad consultation with various sections of society, and developed a policy framework comprising a matrix of four pillars related to governance, pro-poor sustainable growth, human development, and addressing social vulnerabilities. The staff underscored the importance of articulating clearly the policy agenda that would emerge from the PRSP exercise, as this would help in securing, among other things, donor support. ${ }^{34}$

\section{Technical Assistance and Statistics}

\section{Sierra Leone has received substantial technical assistance from the Fund in} recent years and has made progress in improving key areas. Full implementation of the advice and recommendations is, however, constrained by limited institutional capacity. Technical assistance in the fiscal area has focused on strengthening government's expenditure management, revenue administration, and income and indirect tax systems, including the establishment of a tax regime for the country's mineral sector and the introduction of a value-added tax. In the monetary area, technical assistance has aimed at enhancing the central bank's monetary operations, strengthening the capacity to supervise banks, and developing the payments system. With technical assistance from STA, BSL adopted the Fifth Edition of the Balance of Payments Manual and completed the compilation of the balance of payment for 2002 .

\section{There is high demand for statistics with better coverage and quality. ${ }^{35}$ The} authorities are committed to promoting accepted international methodologies and standards in the production and dissemination of official statistics. Although the country participates in the General Data Dissemination Standards (GDDS) project, staff considers that Sierra Leone still has a considerable way to go before it could meet the best practice GDDS recommendations in the range and quality of outputs, as evidenced, for instance, by the problems in reconciling monetary and fiscal data.

34 See further details on the progress with the PRSP in the joint staff assessment, prepared jointly with the World Bank staff. Table 6 provides information on the progress with implementing the HIPC triggers.

${ }^{35}$ See the report of an IMF/World Bank joint mission in March 2004 on the Development of a Strategic Plan for the Statistical System in Sierra Leone that made an initial assessment of the steps required to prepare the statistical strategic plan as part of the beginning of a longer process for national statistical development in Sierra Leone. 


\section{Program Monitoring and Reviews}

60. The authorities are requesting waivers of the nonobservance of the structural performance criteria on the reconciliation of fiscal and monetary data, and on the introduction of new personnel management regulations for the civil service. Regarding the first structural performance criterion, the government was unable to complete it without technical assistance from the Fund, made available in October 2004. On the second structural performance criterion, the authorities had envisaged issuing the regulations to include the new senior executive service. However, given the delays in the finalization of modalities for the senior executive scheme, the authorities have decided to issue separately new regulations only for existing civil servants. This structural measure will constitute a prior action for the fifth review. The authorities are also requesting a waiver for the nonobservance at endMarch 2004 of the quantitative performance criterion on net domestic bank credit to the government. The nonobservance resulted from the nondisbursement of non-HIPC program support in the first quarter of 2004 to which the government could not adequately adjust through expenditure cuts, given the large magnitude of the shortfall. It is expected that this trend would be reversed during subsequent quarters following the receipt of external financing. ${ }^{36}$ Fiscal measures have been undertaken to bring domestic financing closer to the program target by year-end. In particular, the authorities have taken steps in the second half of the year to reduce noninterest current expenditures below the program level. Domestic financing of the budget will also be reduced below the mid-year level by about 0.5 percent of GDP. For program monitoring, the sixth and final review will be completed by May 2005, based on quantitative performance criteria through end-December 2004, a structural performance criterion through end-November 2004, and indicative performance targets for end-September 2004.

\section{STAFF APPRAisal}

\section{Economic recovery has been broad-based, reflecting improved business} confidence. Significant output gains have been made from post-conflict low levels, in agriculture, mining, and manufacturing. However, inflation has also risen since 2003, reflecting exogenous (higher cost of imported fuels) and policy-induced factors (expansionary fiscal and monetary policies), as well as the depreciation of the exchange rate. Despite the augmented activity levels, widespread poverty and high unemployment remain critical socio-economic challenges, which need to be addressed in the medium- to long-term. The full PRSP, to be finalized soon, should serve as an active vehicle for pursuing mediumterm objectives as well as the longer term goals (the MDGs).

\footnotetext{
${ }^{36}$ The US\$14.5 million was disbursed from AfDB in April 2004 and $€ 18$ million was disbursed from EU in September 2004.
} 
62. Real exchange rate depreciation in recent years has assisted Sierra Leone in regaining international competitiveness. However, several disadvantages remain, including poor infrastructure and the high cost of credit, which increase overall production costs. Furthermore, public administration remains inefficient, although taxation and the tariff regime do not impose an overly large burden.

63. Performance under the program at end-March 2004 was mixed. While further progress was made in implementing program structural measures, slippages occurred in other areas of macroeconomic policy, as fiscal management was complicated by unanticipated delays in external budgetary support. Further fiscal tightening and the containment or reduction in domestic debt in the second half of 2004 will be essential to achieve program objectives and safeguard debt sustainability.

64. Provided that the PRGF-supported program is implemented effectively, overall macroeconomic objectives for fiscal 2004 should be attained. Beyond this and also looking ahead in the medium term, the following five areas need specific attention of the authorities.

65. First, fiscal policy will need to assume a central role in supporting macroeconomic stability. To achieve this, a better balance has to be achieved between available resources and expenditure outlays. The government should seek to widen the domestic resource envelope, by enhancing domestic revenue collections and tapping additional revenues from expanded mineral activities. On the expenditure side, prioritization will be essential, with a focus on protecting poverty-related outlays. An operational mediumterm budgetary framework, incorporating mineral revenues, reflecting the PRSP priorities, and discussed with development partners, should be finalized by the authorities as a matter of priority.

66. Second, in order to derive full fiscal and related benefits from the country's considerable mineral potential, the authorities need to expedite the completion of the on-going work on creating a consistent mineral policy framework for Sierra Leone. The mining sector is promising for income and employment generation and, therefore, for poverty reduction. The staff urged the authorities to revise the legislative framework for the mineral sector, to make it consistent with the Core Mineral Policy (already approved by the Cabinet). Furthermore, in order to protect tax revenues, the staff urged the authorities to eliminate or tightly limit the discretionary granting of fiscal incentives to foreign investors.

67. Third, monetary policy and practice need to be strengthened. In effect, this is only possible if strongly supported by appropriate fiscal policy along the lines indicated above. The BSL also needs to be more proactive in containing the growth of private sector credit to control inflation and safeguard against future nonperforming loans. The staff welcomes the BSL's decision to increase reserve and liquidity ratios, as these measures should in the short term assist the central bank in mopping up excess liquidity. Further technical assistance from MFD will be needed in these directions. The strengthening of BSL's policy independence need to be pursued through institutional reforms over the medium-term. 
68. Fourth, macroeconomic policies and structural reforms should aim at enhancing saving and investment, targeting the domestic and foreign private sector. Sustained high growth will require a substantial increase in domestic savings, both private and public. Private savings should improve with enhanced income growth prospects as the economy stabilizes from the post-conflict situation, but also a supportive institutional and policy framework is needed, aimed especially at small- and medium-size savers. The authorities will also need to plan for budgetary savings, within medium-term frameworks, in order to reduce the overdependence of public investment financing on external sources. This issue has been stressed in the context of public expenditure review discussions with the World Bank. In respect of private investment, continued political and economic stability, together with determined efforts to enhance Sierra Leone's investment climate, while addressing governance issues, should assist in attracting both domestic and foreign investors. The staff welcomed the finalization and imminent adoption of the new investment code, developed with the assistance of the World Bank. The main risk to the medium term growth strategy lies in the area of saving and investment. Without substantial progress on the savings side and improvements in the investment rate, growth would slow down. The policy and institutional measures required in this broad area will, therefore, remain critical.

69. Fifth, while current data provision is adequate for Fund's surveillance, efforts should be continued to strengthen the country's statistical base. Progress is being made in the compilation of monetary and balance of payments statistics through implementing the recommendations of previous statistics technical assistance missions. However, staff urged the authorities to continue their efforts to improve other components of the database, especially national accounts, through Fund and other technical assistance.

70. On the basis of the steps taken to reduce noninterest current expenditures with the objective of bringing domestic financing closer to the program target by end-2004, to deal with the slippages in meeting the quantitative performance criterion for end-March on net bank credit to the government, and the introduction of new personnel management regulations for the civil service as a prior action subject to the fifth review under the PRGF arrangement, the staff recommends that the Executive Board grants waivers for the nonobservance of the performance criteria. Based on the commitments made in the attached letter of intent, and the accompanying MEFP, the staff recommends completion of the fifth review under the PRGF arrangement and extension of the arrangement for a three-month period. The staff also recommends that the Ex-Post Assessment (EPA) for Sierra Leone be considered by the Board at the time of the sixth review.

71. The next Article IV consultation with Sierra Leone will be held in accordance with the provisions of the decision on consultation cycles approved on July 15, 2002. 
Figure 1. Sierra Leone: Trends in Interest Rate, Exchange Rate, and Consumer Price Index (CPI), January 2000 - June 2004 (Annual average percent change, unless otherwise indicated)

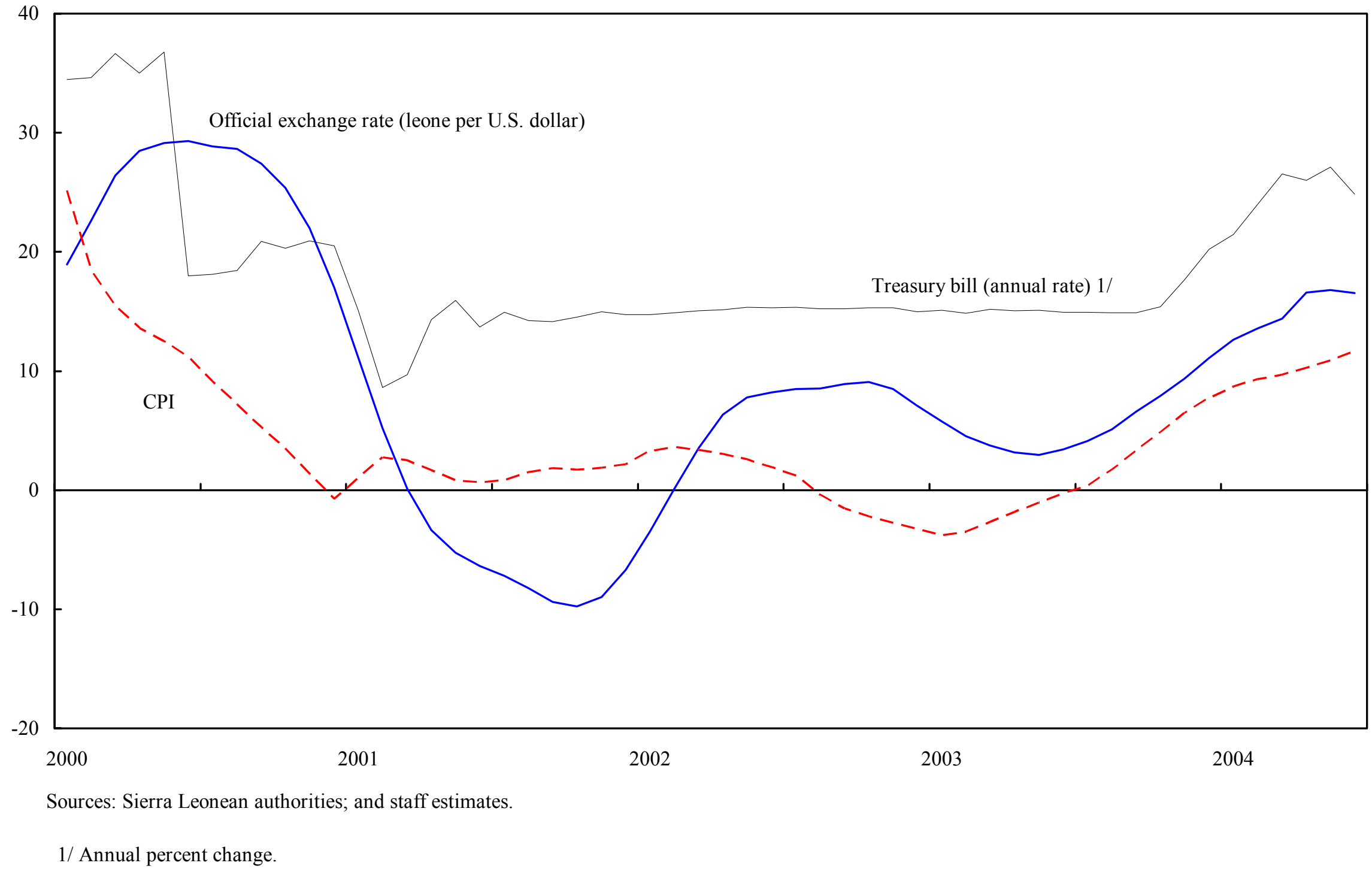


Figure 2. Sierra Leone: Balance of Payments, 2000-04

(In percent of GDP, unless otherwise indicated)

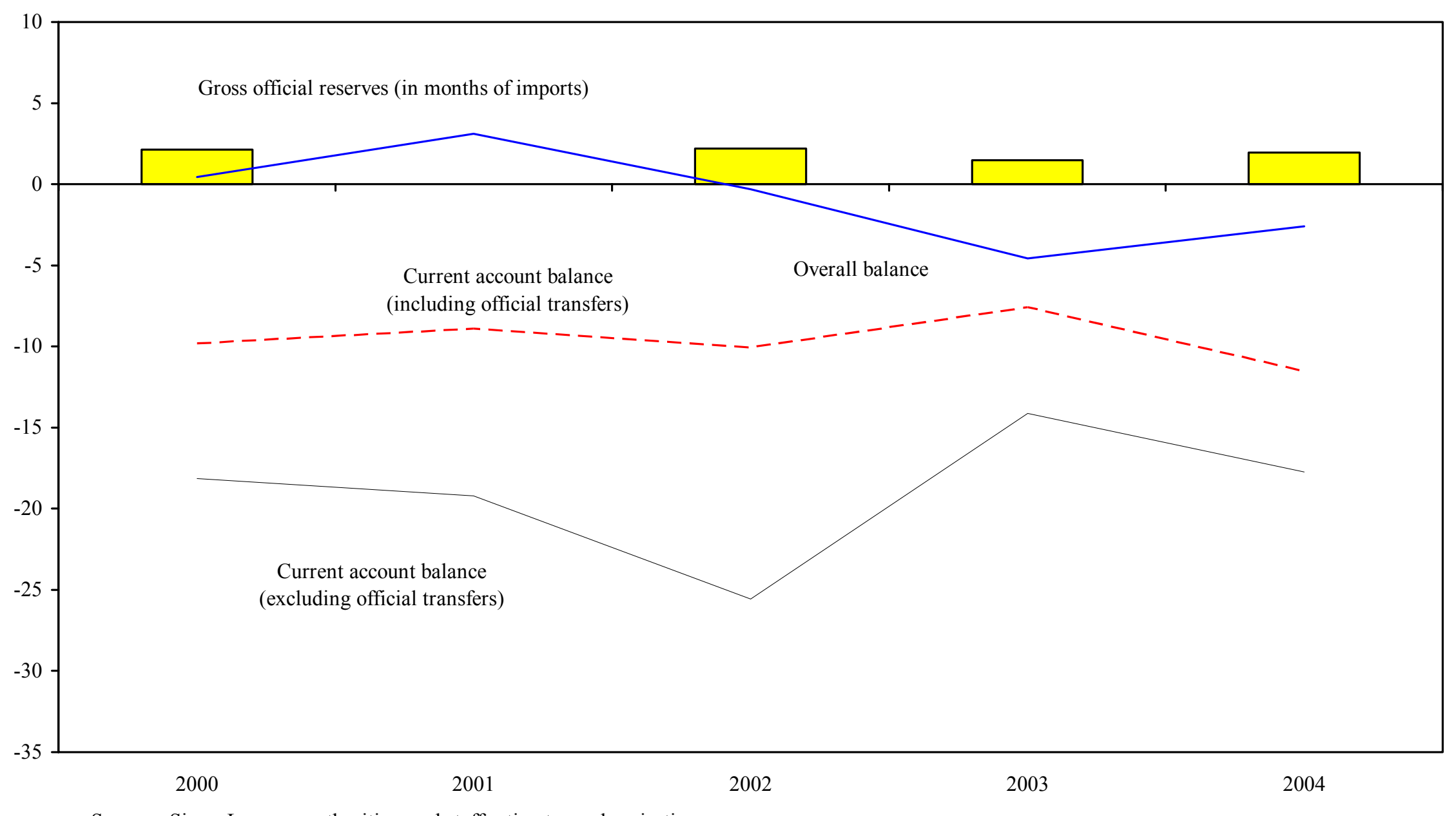

Sources: Sierra Leonean authorities; and staff estimates and projections. 
Figure 3. Sierra Leone: Nominal and Real Effective Exchange Rates, January 2000 - June 2004 1/ $(1995=100)$

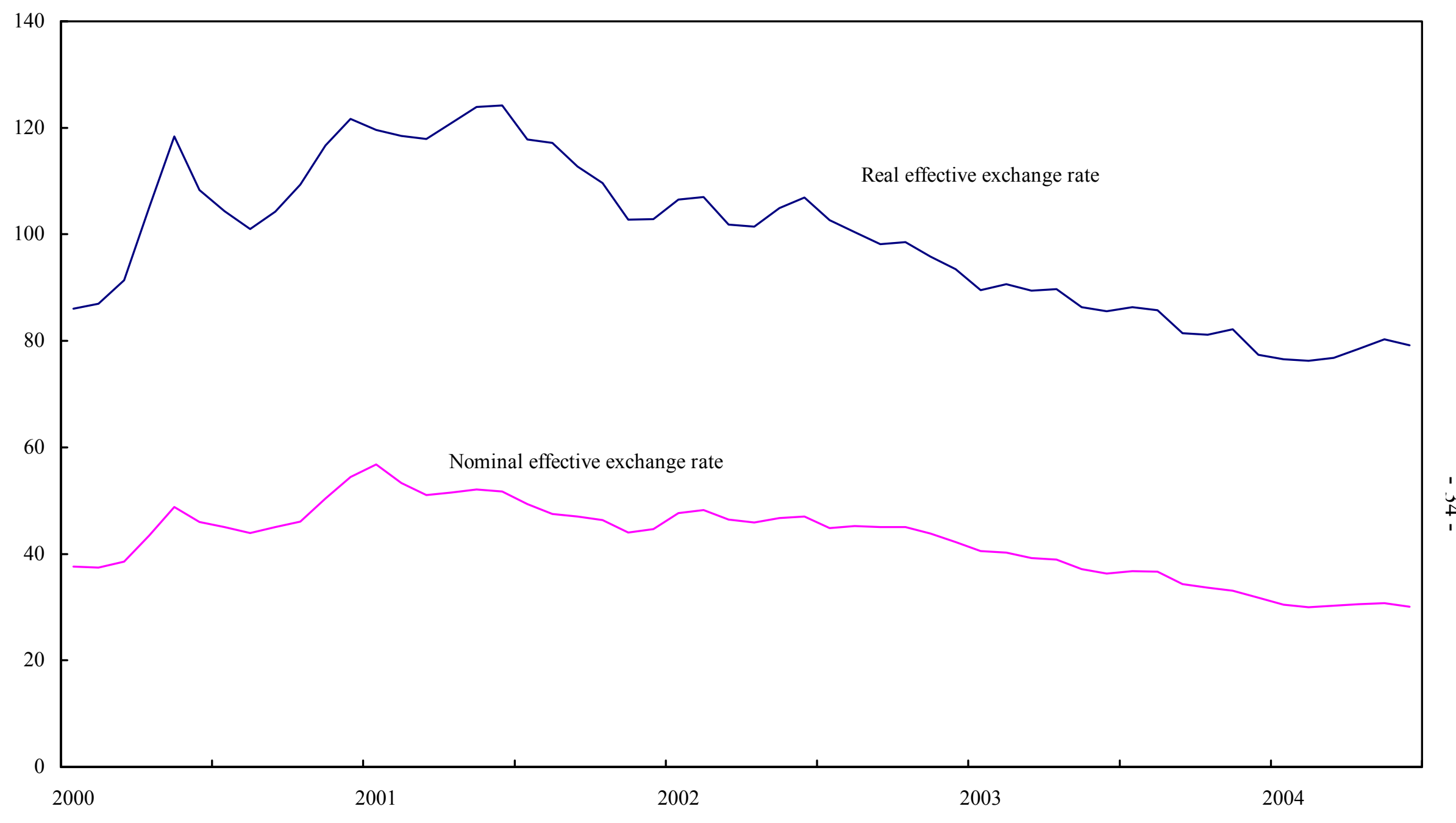

Source: IMF, Information Notice System.

1/ An increase in the indices imblies an anpreciation. 
Figure 4. Sierra Leone: Official and Parallel Exchange Rates, January 2000 - June 2004 (Leones per U.S. dollar)

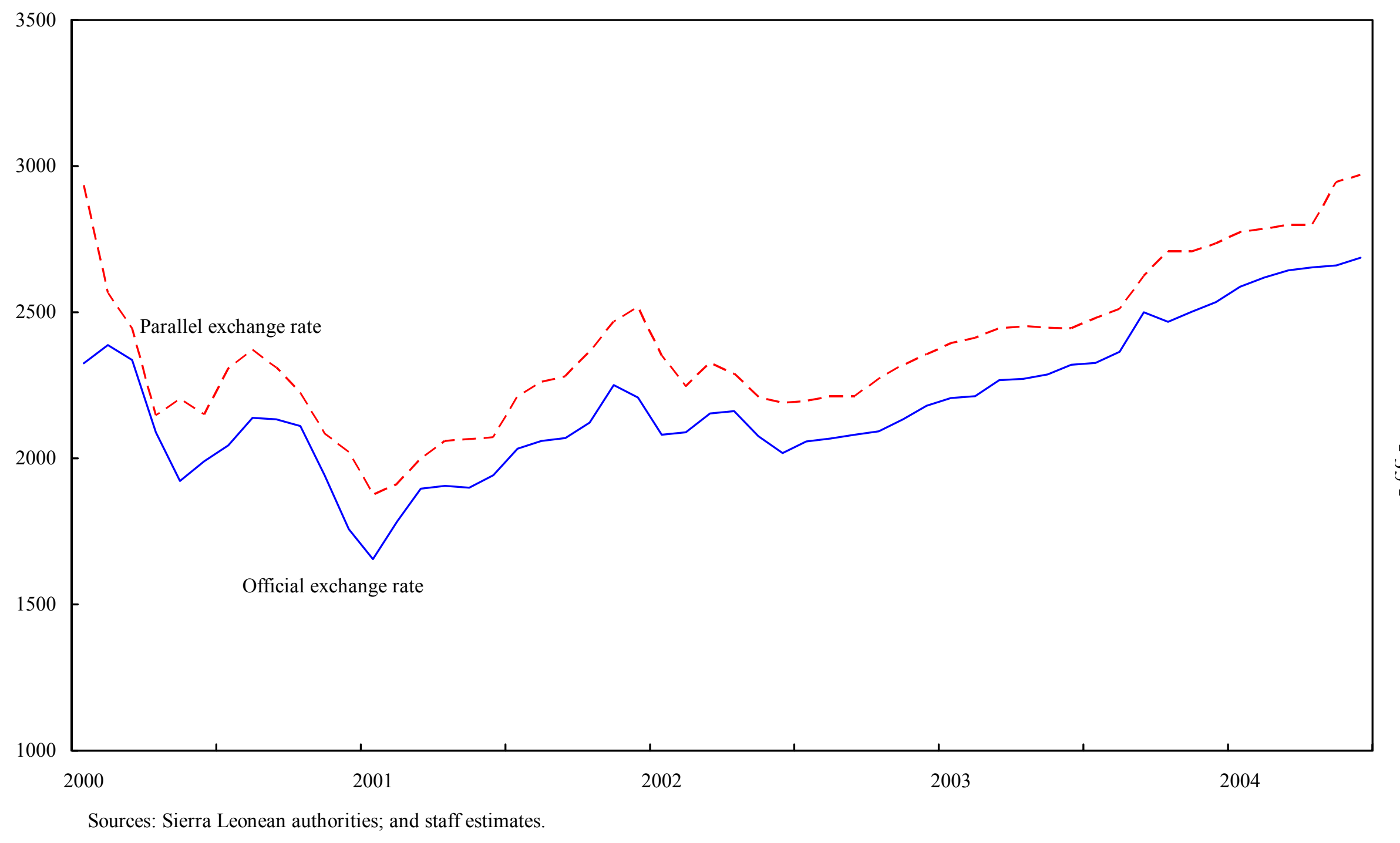




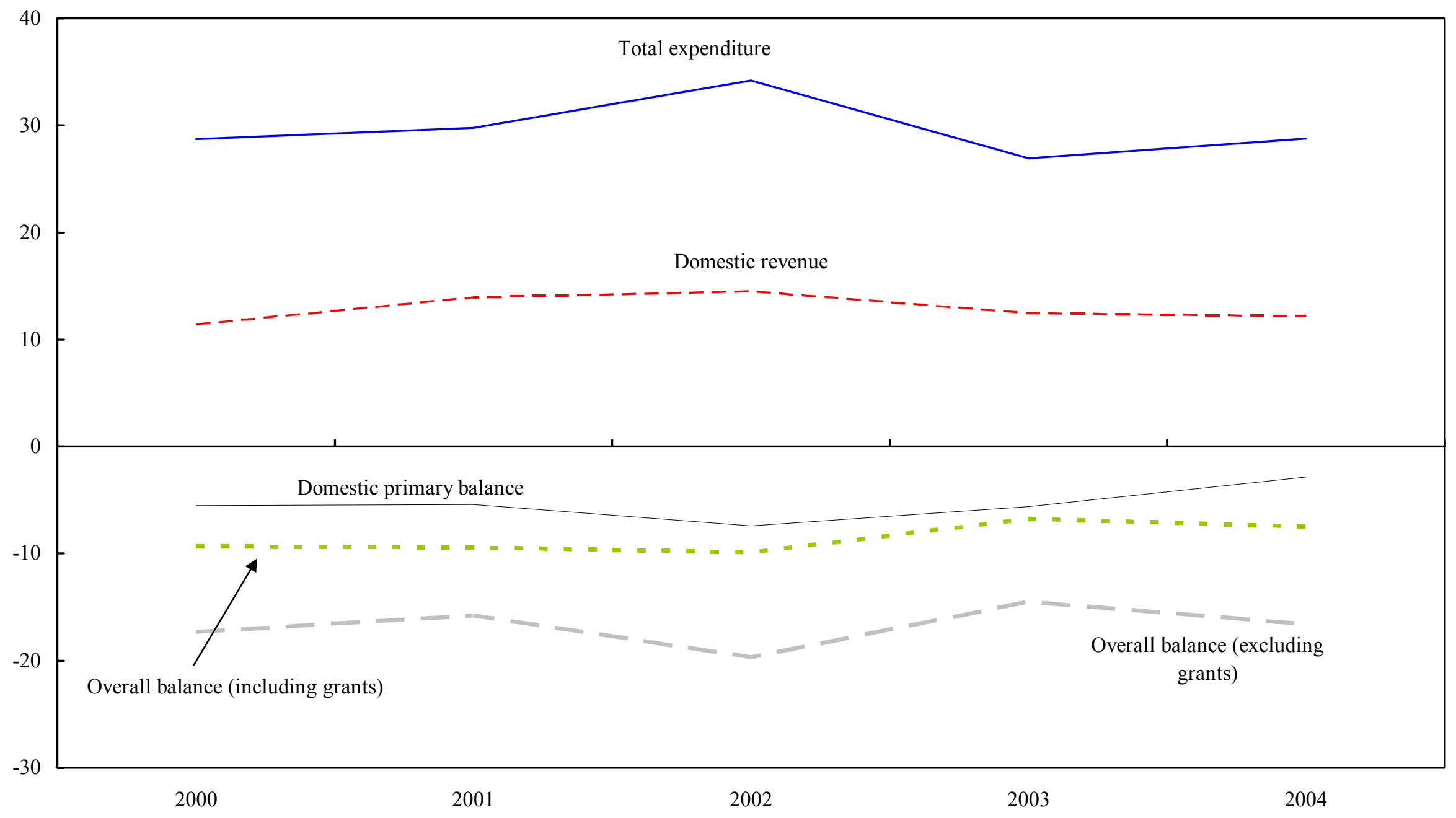

Sources: Sierra Leonean authorities; and staff estimates and projections. 
Figure 6. Sierra Leone: Monetary Developments, 2001-04

(In percent of broad money at the beginning of the period, unless otherwise indicated)

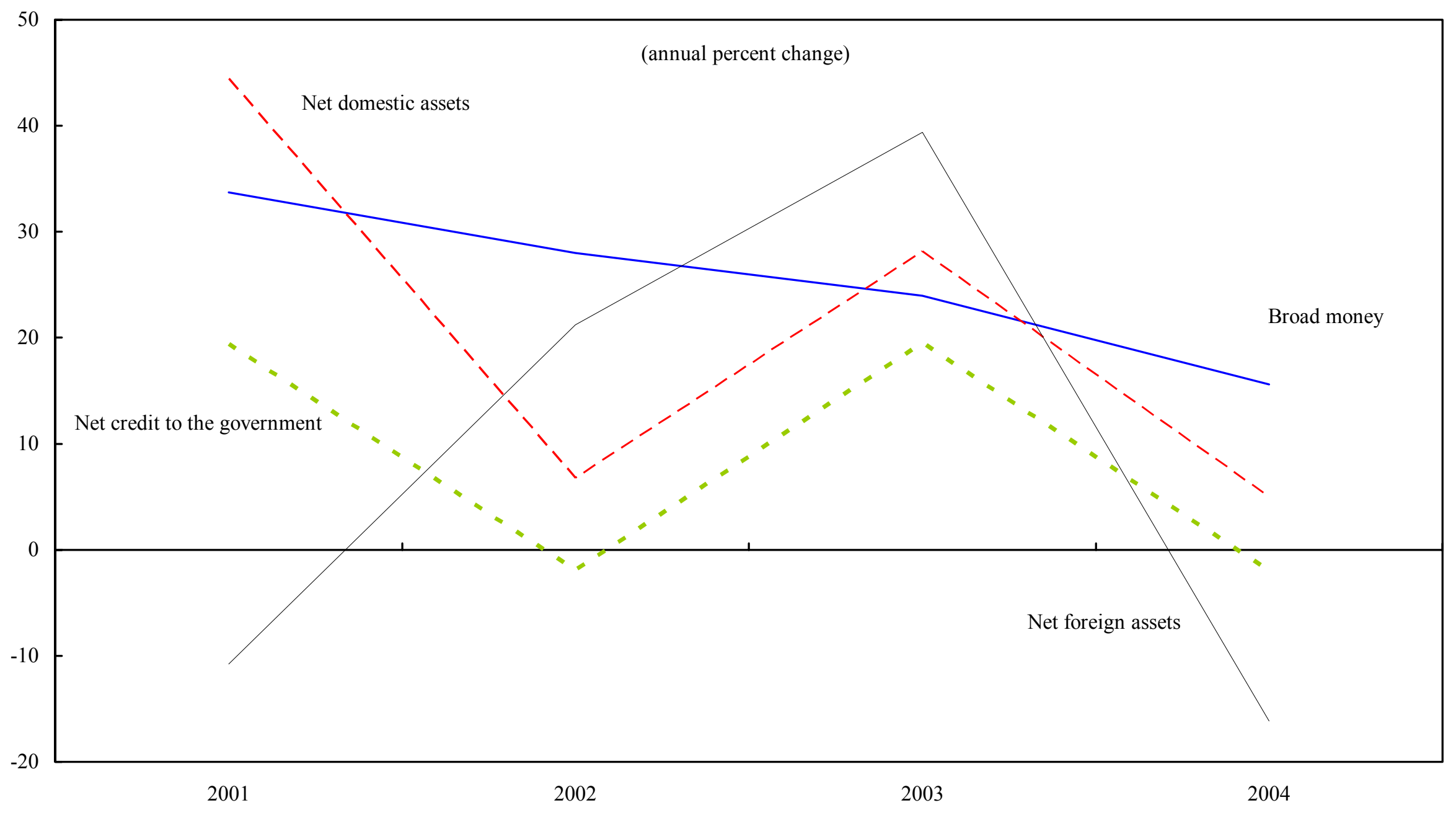

Sources: Sierra Leonean authorities; and staff estimates and projections. 
$-38-$

Table 1. Sierra Leone: Selected Economic and Financial Indicators, 2001-05

\begin{tabular}{rrrrrr}
\hline & 2001 & 2002 & 2003 & 2004 & 2005 \\
\cline { 3 - 4 } & Act. & Est. & Est. & Prog. 1/ & Proj.
\end{tabular}

Income and expenditure

Real GDP 2

GDP deflator

Nominal GDP

Consumer prices (end of period)

Consumer prices (annual average)

Money and credit

Broad money

(including foreign currency deposits)

(excluding foreign currency deposits)

Velocity (level; excl. foreign currency deposits)

Velocity (level; incl. foreign currency deposits)

Domestic credit 3 /

Government 3/

Private sector 3

(annual percentage change)

Reserve money

Interest rate 4

External sector

Exports (U.S. dollars)

Imports (U.S. dollars) 5/

Terms of trade (- deterioration)

Real effective exchange rate (- depreciation; end of period)

Gross domestic investment

Government

Private

Gross national saving

Gross domestic saving

Government

Private

Current account balance, including official transfers

Current account balance, excluding official transfers

Goods and nonfactor services (net)

Unrequited private transfers and factor services (net)

Overall balance of payments

Government domestic revenue

Total expenditure and net lending

Of which : current expenditure

Overall fiscal balance

(commitment basis, excluding grants)

(commitment basis, including grants)

Domestic primary fiscal balance 6/

Domestic financing

Debt service due (incl. to the Fund) after debt relief $7 /$

Debt service due (incl. to the Fund) before debt relief

Net present value of debt-to-exports ratio 8/9/

Memorandum items:

External current account balance, excluding official transfers

Gross international reserves

(in months of imports) 10

GDP (billions of leones)

GDP (millions of U.S. dollars)
(Annual percentage change, unless otherwise indicated)

$\begin{array}{rrrrrr}17.9 & 27.5 & 9.3 & 6.8 & 7.4 & 9.4 \\ 2.0 & -3.7 & 8.2 & 4.6 & 14.4 & 6.9 \\ 20.3 & 22.8 & 18.3 & 11.7 & 22.8 & 17.0 \\ 3.4 & -3.1 & 11.3 & 4.0 & 12.8 & 6.5 \\ 2.6 & -3.7 & 8.2 & 4.8 & 13.6 & 7.3\end{array}$

$\begin{array}{rrrrrr}33.7 & 30.1 & 23.9 & 10.8 & 15.6 & 16.5 \\ 30.8 & 32.0 & 22.9 & 10.8 & 11.3 & 16.6 \\ 6.5 & 6.1 & 5.8 & 5.3 & 6.5 & 6.5 \\ 5.5 & 5.2 & 5.0 & 4.4 & 5.3 & 5.4 \\ 22.5 & 7.9 & 40.6 & 3.0 & 6.3 & 6.6 \\ 19.4 & 0.2 & 19.5 & 0.3 & -2.0 & 2.7 \\ 3.2 & 7.5 & 20.1 & 2.6 & 8.4 & 3.8 \\ 24.6 & 62.3 & 64.5 & 15.4 & 42.0 & 15.5 \\ 29.4 & 24.9 & 22.4 & 12.8 & 6.4 & 15.9 \\ 14.7 & 15.0 & 20.2 & \ldots & 27.0 & 17.3\end{array}$

$\begin{array}{rrrrrr}6.1 & 48.9 & 27.4 & 18.5 & 26.2 & 33.9 \\ 20.6 & 54.4 & 15.6 & 13.2 & 22.7 & 4.9 \\ 1.7 & 0.0 & -0.1 & 0.5 & -2.0 & 0.9 \\ -15.3 & -9.7 & -17.2 & \ldots & \ldots & \ldots\end{array}$

(In percent of GDP)

$\begin{array}{llll}14.3 & 13.5 & 21.4 & 19.9\end{array}$

$\begin{array}{rrrr}4.9 & 3.2 & 8.9 & 7.3\end{array}$

$9.4-10.4$

$\begin{array}{rrrr}6.7 & -2.7 & 9.9 & 11.7\end{array}$

$\begin{array}{lllr}-7.1 & -11.0 & -1.8 & 2.7 \\ -3.3 & -2.1 & -1.2 & -0.5\end{array}$

$\begin{array}{llll}-3.3 & -2.1 & -1.2 & -0.5\end{array}$

$\begin{array}{lrrr}-3.8 & -8.9 & -0.6 & 3.2 \\ -7.6 & -16.3 & -11.5 & -8.3\end{array}$

$\begin{array}{llll}-7.6 & -16.3 & -11.5 & -8.3\end{array}$

$\begin{array}{llll}-14.1 & -31.3 & -17.7 & -13.6\end{array}$

$\begin{array}{llll}-21.3 & -29.8 & -23.2 & -17.2\end{array}$

$\begin{array}{llll}7.0 & -2.7 & 5.2 & 3.4\end{array}$

$\begin{array}{llll}-4.6 & -4.7 & -2.6 & -4.3\end{array}$

$\begin{array}{llll}12.4 & 11.7 & 12.2 & 12.9\end{array}$

$\begin{array}{llll}12.4 & 26.9 & 26.4 & 28.8\end{array}$

$\begin{array}{llll}22.1 & 18.9 & 19.9 & 19.0\end{array}$

$\begin{array}{lllll}24.2 & 22.1 & 18.9 & 19.9 & 19.0\end{array}$

$\begin{array}{lllll}-16.5 & -14.5 & -14.7 & -16.6 & -13.4\end{array}$

$\begin{array}{lllll}-8.3 & -6.7 & -5.5 & -7.5 & -5.3\end{array}$

$\begin{array}{rrrrr}-7.0 & -5.6 & -4.8 & -2.9 & -2.3\end{array}$

$\begin{array}{lllll}0.9 & 4.3 & 0.9 & 1.5 & 1.8\end{array}$

(In percent of exports of goods and nonfactor services)

\begin{tabular}{|c|c|c|c|c|c|}
\hline 73.0 & 9.3 & 7.3 & 11.6 & 10.4 & 7.6 \\
\hline 86.0 & 52.7 & 48.1 & 43.1 & 38.6 & 28.2 \\
\hline 150.6 & 162.3 & 153.6 & 120.7 & 153.3 & 144.7 \\
\hline
\end{tabular}

(In millions of U.S. dollars, unless otherwise indicated)

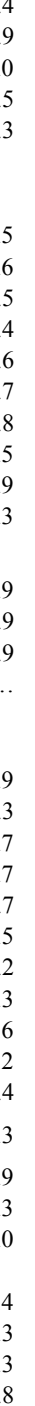

Sources: Sierra Leonean authorities; and staff estimates and projections.

1/ As in Country Report No. 49, Ratios as percent of nominal GDP reflect revised national gross domestic product data.

2/ Based on the trend in growth of real GDP, nominal GDP is not expected to reach the prewar 1996 level of US\$941.7 million until 2005.

3/ Changes as a percentage of beginning-of-period money stock (including foreign currency deposits).

4/ Treasury bill rate (end of period); in percent.

5/ Includes imports purchased with bilateral aid, those related to rehabilitation and reconstruction programs, and imports of embassies and the UN peacekeeping force (UNAMSIL).

6/ Domestic revenue minus total expenditure and net lending, excluding interest payments, and externally financed capital expenditure and disarmament, demobilization, and reintegration (DDR) program.

7/ As percent of exports of goods and services; after Naples (2001) and Cologne flow reschedulings (2002-04), and delivery of possible HIPC initiative assistance.

8/ Net present value (NPV) of debt relative to backward-looking three-year average of exports of goods and services.

9/ Assumed unconditional delivery of enhanced HIPC initiative assistance in 2000.

10 / In months of imports of goods and services of subsequent year.

\section{CInternational Monetary Fund. Not for Redistribution}


Table 2. Sierra Leone: Central Government Financial Operations, 2001-07 1/

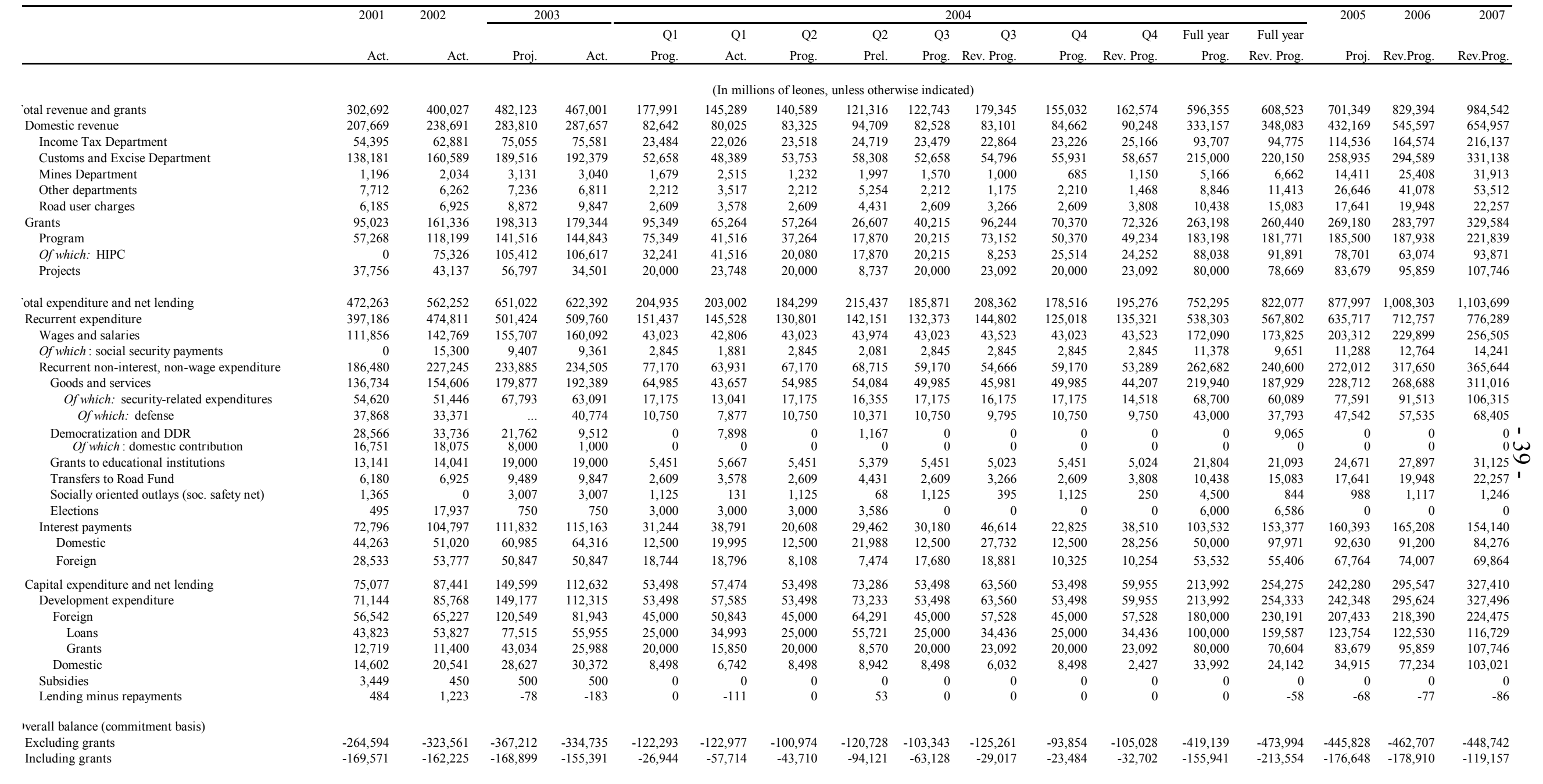


Table 2. Sierra Leone: Central Government Financial Operations, (concluded) 2001-07 1/(concluded)

\begin{tabular}{|c|c|c|c|c|c|c|c|c|c|c|c|c|c|c|c|c|c|}
\hline & \multirow[t]{2}{*}{2001} & \multirow[t]{2}{*}{2002} & \multicolumn{2}{|c|}{2003} & \multicolumn{10}{|c|}{2004} & \multirow[t]{2}{*}{2005} & \multirow[t]{2}{*}{2006} & \multirow[t]{2}{*}{2007} \\
\hline & & & & & Q1 & Q1 & Q2 & Q2 & Q3 & Q3 & Q4 & Q4 & Full year & Full year & & & \\
\hline & Act. & Act. & Proj. & Act. & Prog. & Act. & Prog. & Prel. & Prog. & Rev. Prog. & Prog. & Rev. Prog. & Prog. & Rev. Prog. & Proj. & Rev.Prog. & Rev.Prog. \\
\hline \multicolumn{18}{|c|}{ (In millions of leones, unless otherwise indicated) } \\
\hline 'otal financing & 169,571 & 162,225 & 168,899 & 155,391 & 26,944 & 57,714 & 43,710 & 94,121 & 63,128 & 29,017 & 23,484 & 32,702 & 155,941 & 213,554 & 176,648 & 178,910 & 119,157 \\
\hline Foreign & 624,766 & 143,734 & 89,066 & 66,764 & 51,795 & 36,787 & 13,405 & 83,807 & 61,860 & 22,481 & 10,448 & 56,308 & 138,373 & 199,384 & 118,816 & 164,524 & 157,340 \\
\hline Borrowing & 95,370 & 141,605 & 115,188 & 93,628 & 57,708 & 34,993 & 25,000 & 95,283 & 64,000 & 34,436 & 25,000 & 75,461 & 171,708 & 240,174 & 169,801 & 167,358 & 162,806 \\
\hline Project & 43,823 & 53,827 & 77,515 & 55,955 & 25,000 & 34,993 & 25,000 & 55,721 & 25,000 & 34,436 & 25,000 & 34,436 & 100,000 & 159,587 & 123,754 & 122,530 & 116,729 \\
\hline Program & 51,547 & 87,778 & 37,673 & 37,673 & 32,708 & 0 & 0 & 39,562 & 39,000 & 0 & 0 & 41,025 & 71,708 & 80,587 & 46,048 & 44,828 & 46,077 \\
\hline Amortization 2/ & $-38,515$ & $-48,284$ & $-88,339$ & $-89,590$ & $-46,344$ & $-38,927$ & $-17,666$ & $-19,872$ & $-33,938$ & $-46,089$ & $-21,025$ & $-21,969$ & $-115,812$ & $-126,857$ & $-152,176$ & $-108,893$ & $-113,256$ \\
\hline Change in foreign arrears & & & $-50,820$ & $-51,146$ & 0 & $-3,926$ & 0 & $-21,880$ & 0 & 0 & 0 & 0 & 0 & $-25,806$ & & & \\
\hline Debt relief obtained 2/3/ & 567,911 & 50,413 & 113,037 & 113,871 & 40,432 & 44,646 & 6,071 & 30,276 & 31,798 & 34,133 & 6,472 & 2,817 & 82,477 & 111,873 & 101,191 & 106,058 & 107,790 \\
\hline Domestic & 51,791 & 18,600 & 91,182 & 100,104 & $-23,226$ & 26,204 & 31,930 & 29,591 & 2,893 & 8,161 & 14,662 & $-21,981$ & 24,068 & 41,975 & 59,966 & 16,520 & $-36,049$ \\
\hline Of which: bank & 42,197 & 601 & 34,478 & 56,074 & $-25,000$ & 22,196 & 20,000 & 10,905 & 3,000 & $-10,000$ & 3,500 & $-32,356$ & 1,500 & $-9,255$ & 14,466 & 3,020 & $-32,049$ \\
\hline Privatization receipts & 2,060 & 472 & 221 & 270 & 0 & 26 & 0 & 26 & 0 & 0 & 0 & 0 & 0 & 52 & 0 & 0 & 0 \\
\hline Change in arrears & $-533,199$ & $-3,586$ & $-13,498$ & $-13,539$ & $-1,625$ & $-1,785$ & $-1,625$ & $-2,010$ & $-1,625$ & $-1,625$ & $-1,625$ & $-1,625$ & $-6,500$ & $-7,045$ & $-2,135$ & $-2,135$ & $-2,135$ \\
\hline Unaccounted (- $=$ overfinancing of the budget) & 24,152 & 3,004 & 5,880 & 1,792 & 0 & $-3,518$ & 0 & $-17,293$ & 0 & 0 & 0 & 0 & 0 & $-20,812$ & 0 & 0 & 0 \\
\hline Financing gap & 0 & 0 & 3,952 & 0 & 0 & 0 & 0 & 0 & 0 & 0 & 0 & 0 & 0 & 0 & 0 & 0 & 0 \\
\hline \multicolumn{18}{|l|}{ \emorandum items: } \\
\hline Nominal GDP & $1,600,169$ & $1,965,170$ & \#\#\#\#\# & $2,310,767$ & $2,581,140$ & $2,581,140$ & $2,581,140$ & $2,581,140$ & $2,581,140$ & $2,854,489$ & $2,581,140$ & $2,854,489$ & $2,581,140$ & $2,854,489$ & $3,338,710$ & \#\#\#\#\#\# & $4,212,226$ \\
\hline Total HIPC initiative interim assistance & 0.0 & 75,326 & 105,412 & 106,617 & 32,241 & 41,516 & 20,080 & 17,870 & 20,215 & 8,253 & 25,514 & 24,252 & 88,038 & 91,891 & 78,701 & 63,074 & 93,871 \\
\hline Total HIPC initiative interim assistance (as percent of & 0.0 & 3.8 & 4.6 & 4.6 & 1.2 & 1.6 & 0.8 & 0.7 & 0.8 & 0.3 & 1.0 & 0.8 & 3.4 & 3.2 & 2.4 & 1.7 & 2.2 \\
\hline Total poverty expenditures (percent of tot. expenditure: & 15.4 & 21.4 & $\ldots$ & 22.5 & 26.8 & 14.2 & 26.6 & $\ldots$ & 20.3 & & 19.5 & $\ldots$ & 23.6 & 18.3 & $\ldots$ & $\ldots$ & $\ldots$ \\
\hline \multicolumn{18}{|c|}{ (In percent of GDP, unless otherwise indicated) } \\
\hline Domestic revenue & 13.0 & 12.1 & 12.3 & 12.4 & 2.9 & 3.1 & 2.9 & 3.7 & 2.9 & 2.9 & 3.0 & 3.2 & 12.9 & 12.2 & 12.9 & 14.5 & 15.5 \\
\hline Total expenditure and net lending & 29.5 & 28.6 & 28.2 & 26.9 & 7.2 & 7.9 & 6.5 & 8.3 & 6.5 & 7.3 & 6.3 & 6.8 & 29.1 & 28.8 & 26.3 & 26.7 & 26.2 \\
\hline Of which: current expenditure & 24.8 & 24.2 & 21.7 & 22.1 & 5.9 & 5.6 & 5.1 & 5.5 & 5.1 & 5.6 & 4.8 & 5.2 & 20.9 & 19.9 & 19.0 & 18.9 & 18.4 \\
\hline Of which: domestic interest expenditure & 2.8 & 2.6 & 2.6 & 2.8 & 0.5 & 0.8 & 0.5 & 0.9 & 0.5 & 1.0 & 0.5 & 1.0 & 1.9 & 3.4 & 2.8 & 2.4 & 2.0 \\
\hline \multicolumn{18}{|l|}{ Overall fiscal balance (commitment basis) } \\
\hline Including grants & -10.6 & $-8.34 /$ & -7.3 & -6.7 & -1.0 & -2.2 & -1.7 & -3.6 & -2.4 & -1.0 & -0.9 & -1.1 & -6.0 & -7.5 & -5.3 & -4.7 & -2.8 \\
\hline Excluding grants & -16.5 & -16.5 & -15.9 & -14.5 & -4.7 & -4.8 & -3.9 & -4.7 & -4.0 & -4.4 & -3.6 & -3.7 & -16.2 & -16.6 & -13.4 & -12.3 & -10.7 \\
\hline Domestic primary balance $5 /$ & -7.7 & -7.0 & -5.2 & -5.6 & -1.8 & -1.0 & -1.4 & -1.0 & -1.1 & -0.7 & -1.0 & -0.3 & -5.3 & -3.0 & -2.3 & -2.1 & -1.7 \\
\hline Domestic financing & 3.2 & 0.9 & 3.9 & 4.3 & -0.9 & 1.0 & 1.2 & 1.1 & 0.1 & 0.3 & 0.6 & -0.8 & 0.9 & 1.5 & 1.8 & 0.4 & -0.9 \\
\hline Total wages and salaries & 7.0 & 7.3 & 6.7 & 6.9 & 1.7 & 1.7 & 1.7 & 1.7 & 1.7 & 1.5 & 1.7 & 1.5 & 6.7 & 6.1 & 6.1 & 6.1 & 6.1 \\
\hline Total wages and salaries (percent of dom. revenue) & 53.9 & 59.8 & 54.9 & 55.7 & 57.6 & 53.5 & 57.1 & 46.4 & 57.7 & 52.4 & 56.2 & 48.2 & 51.7 & 49.9 & 47.0 & 42.1 & 39.2 \\
\hline
\end{tabular}

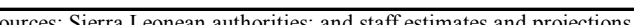

/ Includes the disarmament, demobilization, and reintegration (DDR) program, which is managed outside the budget by a private firm hired by the DDR donors.

To enhance transparency, actual debt service payments in 2002 and projections beyond refer to debt service due before debt relief, and debt relief obtained is shown separately as a financing item

ebt relief obtained encompasses a rescheduling on Naples terms following the agreed minute with the Paris Club from October 2001 onward,

ologne flow rescheduling for 2002-04 agreed by the Paris Club at the decision point in February 2002, and comparable relief by other creditors. Interim HIPC initiative assistance by multilateral creditors is shown as grants.

Debt relief obtained in 2001 includes rescheduling of outstanding arrears of $\$ 239$ million by Paris Club and other creditors.

In this presentation of the overall fiscal balance, HIPC initiative relief is shown as program grants consistent with revised presentation in the balance of payments from 2002 onward. In the 2002 program, HIPC initiative relief was presented as extern

Domer reves. 
Table 3. Sierra Leone: Monetary Survey, December 2001-December 2005
(In millions of leones; at actual exchange rates unless otherwise indicated)

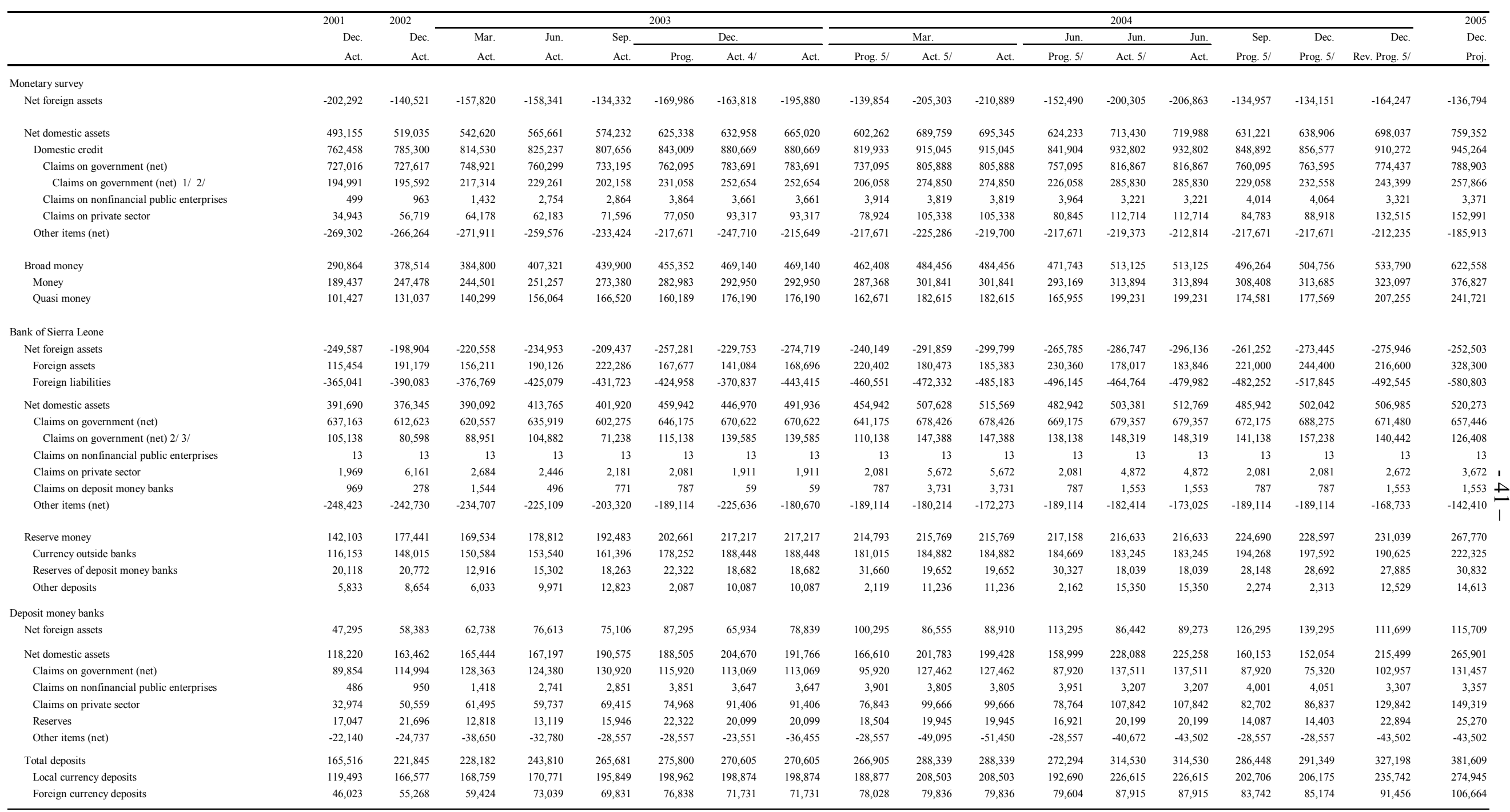

Sources: Sierra Leonean authorities; and staff estimates and projection

1/ New special non-interest-bearing government stocks were issued by the Bank of Sierra Leone to cover foreign exchange valuation losses incurred.

2/ Excluding non-interest-bearing stock

4/ Items denominated in foreign currencies are valued at the program exchange rate of Le 2,142.8 per US\$1 (as specified in the TMU of March 2003).

$5 /$ Items denominated in foreign currencies are valued at the program exchange rate of Le 2,600.0 per US\$1 (as specified in the TMU of January 2004). 
Table 4. Sierra Leone: Balance of Payments, 2002-07 (In millions of U.S. dollars, unless otherwise indicated)

\begin{tabular}{|c|c|c|c|c|c|c|c|c|c|}
\hline & $\begin{array}{r}2002 \\
\text { Prev. Est. }\end{array}$ & $\begin{array}{l}2002 \\
\text { Act. } 1 /\end{array}$ & $\begin{array}{l}2003 \\
\text { Prog. }\end{array}$ & $\begin{array}{l}2003 \\
\text { Proj. }\end{array}$ & $\begin{array}{l}2004 \\
\text { Prog. }\end{array}$ & $\begin{array}{l}2004 \\
\text { Proj. }\end{array}$ & $\begin{array}{l}2005 \\
\text { Proj. }\end{array}$ & $\begin{array}{l}2006 \\
\text { Proj. }\end{array}$ & $\begin{array}{l}2007 \\
\text { Proj. }\end{array}$ \\
\hline urrent account balance & -79.1 & -44.6 & -133.1 & -75.1 & -130.1 & -120.4 & -95.8 & -62.8 & -72.9 \\
\hline Balance on goods & -123.6 & -140.1 & -192.4 & -148.5 & -157.4 & -177.2 & -132.5 & -92.5 & -111.8 \\
\hline Exports, f.o.b. & 103.7 & 114.8 & 112.9 & 146.3 & 161.8 & 184.6 & 247.1 & 289.9 & 294.0 \\
\hline Of which: Rutile & 0.0 & 0.0 & 0.0 & 0.0 & 1.0 & 0.0 & 25.0 & 49.1 & 50.7 \\
\hline Of which: Diamonds 2/ & 96.7 & 96.7 & 102.5 & 126.2 & 143.9 & 162.3 & 180.9 & 197.7 & 198.6 \\
\hline Of which: Kimberlite & 0.0 & 0.0 & 0.0 & 0.0 & 0.0 & 19.0 & 29.0 & 44.0 & 43.0 \\
\hline Imports, f.o.b. & -227.3 & $-254.93 /$ & -305.3 & -294.8 & -319.2 & -361.8 & -379.6 & -382.4 & -405.8 \\
\hline Of which: Petroleum products & -38.5 & -44.5 & -47.0 & -66.6 & -58.3 & -82.3 & -90.2 & -92.8 & -97.6 \\
\hline Of which: Rice & -23.4 & -23.4 & -17.6 & -23.2 & -22.5 & -24.6 & -25.7 & -27.5 & -29.4 \\
\hline Balance on services & -53.4 & -42.4 & -77.3 & -62.6 & -71.4 & -65.2 & -67.1 & -68.2 & -69.3 \\
\hline Credit & 38.9 & 38.3 & 44.3 & 51.0 & 45.3 & 53.8 & 56.9 & 60.1 & 63.6 \\
\hline Debit & -92.3 & -80.8 & -121.6 & -113.6 & -116.7 & -119.0 & -124.0 & -128.4 & -132.9 \\
\hline Income & -31.2 & -29.2 & -32.5 & -27.0 & -30.4 & -27.6 & -31.1 & -34.2 & -32.1 \\
\hline Credit & 4.2 & 18.3 & 4.4 & 19.8 & 4.5 & 20.3 & 20.7 & 21.2 & 21.7 \\
\hline Debit & -35.4 & -47.5 & -36.9 & -46.9 & -34.9 & -47.9 & -51.9 & -55.4 & -53.8 \\
\hline Interest payments due before debt relief 4 / & -26.3 & -26.3 & -26.0 & -22.8 & -21.6 & -21.5 & -24.6 & -25.7 & -23.7 \\
\hline Current transfers & 129.1 & 167.2 & 169.1 & 163.0 & 129.0 & 149.7 & 135.0 & 132.1 & 140.2 \\
\hline Public (net) $5 /$ & 121.4 & $69.07 /$ & 161.0 & 64.7 & 119.7 & 64.9 & 61.8 & 60.1 & 69.3 \\
\hline Of which: HIPC grants & 35.8 & 35.8 & 45.8 & 45.4 & 33.9 & 35.0 & 27.3 & 21.1 & 30.6 \\
\hline Private (net) $6 /$ & 7.7 & $98.27 /$ & 8.1 & 98.4 & 9.3 & 84.8 & 73.2 & 72.1 & 70.9 \\
\hline urrent account balance, excl. public transfers & -200.5 & -113.6 & -294.1 & -139.7 & -249.8 & -185.2 & -157.5 & -122.9 & -142.2 \\
\hline 'apital and financial account & 76.3 & 41.7 & 97.3 & 29.7 & 92.4 & 93.1 & 45.9 & 32.8 & 52.4 \\
\hline Capital account & 5.5 & 7.6 & 30.0 & 16.4 & 16.8 & 28.2 & 31.2 & 34.2 & 37.2 \\
\hline Project grants & 5.5 & 5.5 & 30.0 & 14.2 & 16.8 & 26.1 & 29.1 & 32.1 & 35.1 \\
\hline Private capital transfers & 0.0 & 2.1 & & 2.2 & & 2.2 & 2.2 & 2.2 & 2.2 \\
\hline Financial account & 70.8 & 34.1 & 67.3 & 13.3 & 75.6 & 64.9 & 14.7 & -1.4 & 15.2 \\
\hline Direct investment and portfolio investment & 3.9 & 1.7 & 4.4 & $21.08 /$ & 26.2 & $29.59 /$ & 7.7 & -2.3 & 2.7 \\
\hline Other investment & 66.9 & 32.4 & 62.9 & -7.7 & 49.4 & 35.4 & 7.0 & 0.9 & 12.5 \\
\hline Public sector loans (net) & 43.9 & 43.9 & 27.1 & 10.8 & 19.0 & 41.4 & 6.1 & 19.6 & 16.1 \\
\hline Of which: disbursements & 66.8 & 66.8 & 78.5 & 48.4 & 63.6 & 88.4 & 59.0 & 56.0 & 53.0 \\
\hline Of which: program loans & 40.9 & 40.9 & 22.2 & 15.9 & 27.6 & 29.5 & 16.0 & 15.0 & 15.0 \\
\hline amortization due before debt relief & -22.9 & -22.9 & $-51.410 /$ & $-37.510 /$ & $-44.510 /$ & $-47.010 /$ & -52.9 & -36.4 & -36.9 \\
\hline Private sector loans (net) & $23.111 /$ & 0.0 & $35.811 /$ & 0.0 & $30.311 /$ & 26.4 & 25.6 & -4.0 & 11.0 \\
\hline Change in net foreign assets of commercial banks & & -5.3 & & -8.7 & & -17.4 & -15.0 & -8.7 & -8.7 \\
\hline Other, including errors and omissions & & -6.2 & & -9.8 & & -15.0 & -9.7 & -5.9 & -5.9 \\
\hline Iverall balance & -2.7 & -2.9 & -35.9 & -45.4 & -37.8 & -27.2 & -49.8 & -30.0 & -20.5 \\
\hline inancing & 2.7 & 2.9 & 35.9 & 45.4 & 37.8 & 27.2 & 49.8 & 30.0 & 20.5 \\
\hline Change in net foreign assets of the central bank (- increase) & -27.9 & -27.7 & 1.9 & 10.2 & 6.0 & -4.9 & -17.8 & -34.5 & -55.9 \\
\hline Change in reserve assets (- increase) & -32.7 & -32.3 & -2.4 & 25.2 & -31.6 & -22.5 & -30.0 & -30.0 & -40.0 \\
\hline Net Fund credit & 4.8 & 4.6 & 4.3 & -15.1 & 37.6 & 17.6 & 12.2 & -4.5 & -15.9 \\
\hline Disbursements & 36.3 & 36.0 & 37.3 & 19.6 & 60.0 & 41.1 & 20.4 & 0.0 & 0.0 \\
\hline Repayments & -31.4 & -31.4 & -33.0 & -34.6 & -22.5 & -23.5 & -8.3 & -4.5 & -15.9 \\
\hline Exceptional financing & 30.6 & 30.6 & 34.0 & 35.2 & 31.7 & 32.1 & 35.2 & 35.5 & 35.1 \\
\hline Change in arrears $(+$ increase) & $6.712 /$ & $6.712 /$ & $-14.212 /$ & $-13.812 /$ & 0.0 & $-9.512 /$ & 0.0 & 0.0 & 0.0 \\
\hline Debt relief 13/ & 23.9 & 23.9 & 48.2 & 49.1 & 31.7 & 41.6 & 35.2 & 35.5 & 35.1 \\
\hline Financing gap & 0.0 & 0.0 & 0.0 & 0.0 & 0.0 & 0.0 & $-32.514 /$ & -28.9 & -41.3 \\
\hline \multicolumn{10}{|l|}{ Temorandum items: } \\
\hline & \multicolumn{9}{|c|}{ (In percent of GDP) } \\
\hline Current account & -10.1 & $-4.815 /$ & -15.2 & -7.6 & -16.3 & -11.5 & -8.3 & -5.0 & -5.3 \\
\hline Current account, excluding public transfers & -25.6 & $-12.115 /$ & -33.6 & -14.1 & -31.3 & -17.7 & -13.6 & -9.7 & -10.4 \\
\hline Overall balance of payments & -0.3 & -0.3 & -4.1 & -4.6 & -4.7 & -2.6 & -4.3 & -2.4 & -1.5 \\
\hline Exports, f.o.b. & 13.2 & 12.3 & 12.9 & 14.8 & 20.3 & 17.7 & 21.3 & 22.9 & 21.4 \\
\hline Imports, c.i.f. & 33.8 & 31.7 & 40.5 & 35.0 & 46.5 & 40.7 & 38.4 & 35.5 & 34.8 \\
\hline Gross official reserves (in millions of US dollars) & 84.6 & 84.6 & 87.0 & 59.4 & 90.7 & 81.9 & 111.9 & 141.9 & 181.9 \\
\hline Gross official reserves (in months of imports) 16/ & 2.4 & 2.5 & 2.2 & 1.5 & 2.2 & 2.0 & 2.6 & 3.2 & 3.9 \\
\hline
\end{tabular}

Sources: Sierra Leonean authorities; and staff estimates and projections.

1/ BOP data for 2002 were compiled for the first time on the basis of the Balance of Payment Manual Fifth Edition (BPM5), which has led to a number of significant changes.

2/ Includes unrecorded diamond exports estimated from partner-country data.

3/ The increase in imports is due to a better measurement of non-dutiable imports.

4/ Official interest payments due, including Fund charges.

5/ Includes mostly program grants.

6/ Includes worker remittances and transfers to NGOs.

7/ The adoption of the Balance of Payment Fifth Edition for 2002 data has led to a better measurement of private transfers through the use of new survey instruments and through a reclassification of items as private transfers that were previously counted as public transfers, which led to significant changes in private and current

transfers.

8/ Includes investment related to the rehabilitation of the Koidu Kimberlite mine

9/ Assumes investment into rutile mining, financed by foreign loans, foreign investment, and government on-lending of an EU grant.

10/ Amortization due increases in 2003 and beyond because of debt service payments falling due on previously rescheduled arrears.

11/ Includes capital outflows associated with unrecorded diamond exports, change in trade credit, and errors and omissions.

12/ The arrears accumulation in 2002 is due to technical arrears that were accumulated while negotiations with bilateral creditors on rescheduling were not yet

concluded. The arrears reduction in 2003 results from the implementation of arrear rescheduling agreements with the EU, the Saudi Fund for Economic Development,

and the OPEC Fund. In 2004, arrear clearance operations with the EU and the OPEC Fund are completed.

13/ This reflects the rescheduling on Cologne terms for the period 2002-04 agreed by the Paris Club at the decision point in February 2002, and comparable relief by other creditors.

14/ The financing gap in 2005 could be closed with disbursements from the Fund under the present arrangement and a possible successor arrangement.

15/ The upward revision in the current account balance-to-GDP ratios reflects revisions due to the adoption of BPM5, and a significant upward revision in GDP.

16/ In months of imports of total goods and services of subsequent year. 
Table 5. Sierra Leone: Selected Economic and Financial Indicators, 2004-09

\begin{tabular}{|c|c|c|c|c|c|c|c|}
\hline & \multicolumn{2}{|c|}{2004} & \multirow{2}{*}{$\begin{array}{l}2005 \\
\text { Proj. }\end{array}$} & \multirow{2}{*}{$\begin{array}{l}2006 \\
\text { Proj. }\end{array}$} & \multirow{2}{*}{$\begin{array}{l}2007 \\
\text { Proj. }\end{array}$} & \multirow{2}{*}{$\begin{array}{l}2008 \\
\text { Proj. }\end{array}$} & \multirow{2}{*}{$\begin{array}{l}2009 \\
\text { Proj }\end{array}$} \\
\hline & Prog. 1/ & Proj. & & & & & \\
\hline & \multicolumn{7}{|c|}{ (Annual percentage change, unless otherwise indicated) } \\
\hline \multicolumn{8}{|l|}{ Income and expenditure } \\
\hline Real GDP 2/ & 6.8 & 7.4 & 9.4 & 7.1 & 6.5 & 6.0 & 6.0 \\
\hline GDP deflator & 4.6 & 14.4 & 6.9 & 5.6 & 4.8 & 3.8 & 3.3 \\
\hline Nominal GDP & 11.7 & 22.8 & 17.0 & 13.1 & 11.6 & 10.1 & 9.5 \\
\hline Consumer prices (end of period) & 4.0 & 12.8 & 6.5 & 5.5 & 4.5 & 3.5 & 3.5 \\
\hline Consumer prices (annual average) & 4.8 & 13.6 & 7.3 & 6.0 & 5.0 & 4.0 & 3.5 \\
\hline \multicolumn{8}{|l|}{ Money and credit } \\
\hline \multicolumn{8}{|l|}{ Broad money } \\
\hline (including foreign currency deposits) & 10.8 & 15.6 & 16.5 & 14.4 & 11.7 & 10.8 & 9.6 \\
\hline (excluding foreign currency deposits) & 10.8 & 11.3 & 16.6 & 13.2 & 11.6 & 10.4 & 9.6 \\
\hline Velocity (level; excl. foreign currency deposits) & 5.3 & 6.5 & 6.5 & 6.5 & 6.5 & 6.4 & 6.4 \\
\hline Velocity (level; incl. foreign currency deposits) & 4.4 & 5.3 & 5.4 & 5.4 & 5.4 & 5.3 & 5.3 \\
\hline Private sector $3 /$ & 2.6 & 8.4 & 3.8 & 3.6 & 3.7 & 3.8 & 4.4 \\
\hline (annual percentage change) & 15.4 & 42.0 & 15.5 & 14.6 & 14.7 & 14.7 & 16.7 \\
\hline Reserve money & 12.8 & 6.4 & 15.9 & 12.3 & 11.0 & 9.4 & 9.1 \\
\hline Interest rate $4 /$ & $\ldots$ & 27.0 & 17.3 & 16.0 & 15.0 & 14.0 & 13.5 \\
\hline \multicolumn{8}{|l|}{ External sector } \\
\hline Exports (U.S. dollars) & 18.5 & 26.2 & 33.9 & 17.3 & 1.4 & 10.1 & 15.8 \\
\hline Imports (U.S. dollars) 5/ & 13.2 & 22.7 & 4.9 & 0.7 & 6.1 & 4.8 & 5.7 \\
\hline Terms of trade (- deterioration) & 0.5 & -2.0 & 0.9 & 1.2 & 0.6 & 0.4 & 0.7 \\
\hline \multirow[t]{2}{*}{ Real effective exchange rate (- depreciation; end of period) } & $\ldots$ & $\ldots$ & $\ldots$ & $\ldots$ & $\ldots$ & $\ldots$ & $\ldots$ \\
\hline & \multicolumn{7}{|c|}{ (In percent of GDP) } \\
\hline Gross domestic investment & 13.5 & 21.4 & 19.9 & 20.6 & 21.1 & 21.2 & 21.5 \\
\hline Government & 3.2 & 8.9 & 7.3 & 7.8 & 7.8 & 7.8 & 8.1 \\
\hline Private & 10.4 & 12.5 & 12.7 & 12.8 & 13.3 & 13.4 & 13.4 \\
\hline Gross national saving & -2.7 & 9.9 & 11.7 & 15.7 & 15.8 & 16.2 & 17.7 \\
\hline Gross domestic saving & -11.0 & -1.8 & 2.7 & 7.9 & 7.9 & 9.7 & 12.4 \\
\hline Government & -2.1 & -1.2 & -0.5 & 0.7 & 1.5 & 2.1 & 2.7 \\
\hline Current account balance, excluding official transfers & -31.3 & -17.7 & -13.6 & -9.7 & -10.4 & -9.1 & -6.9 \\
\hline Goods and nonfactor services (net) & -29.8 & -23.2 & -17.2 & -12.7 & -13.2 & -11.6 & -9.1 \\
\hline Unrequited private transfers and factor services (net) & -2.7 & 5.2 & 3.4 & 2.8 & 2.6 & 2.3 & 2.0 \\
\hline Overall balance of payments & -4.7 & -2.6 & -4.3 & -2.4 & -1.5 & -1.6 & -2.4 \\
\hline Government domestic revenue & 11.7 & 12.2 & 12.9 & 14.5 & 15.5 & 16.4 & 17.3 \\
\hline Total expenditure and net lending & 26.4 & 28.8 & 26.3 & 26.7 & 26.2 & 25.9 & 26.1 \\
\hline Of which : current expenditure & 18.9 & 19.9 & 19.0 & 18.9 & 18.4 & 18.1 & 18.0 \\
\hline \multicolumn{8}{|l|}{ Overall fiscal balance } \\
\hline (commitment basis, excluding grants) & -14.7 & -16.6 & -13.4 & -12.3 & -10.7 & -9.6 & -8.8 \\
\hline (commitment basis, including grants) & -5.5 & -7.5 & -5.3 & -4.7 & -2.8 & -2.9 & -3.4 \\
\hline Domestic primary fiscal balance $6 /$ & -4.8 & -2.9 & -2.3 & -2.1 & -1.7 & -1.9 & -1.9 \\
\hline \multirow[t]{2}{*}{ Domestic financing } & 0.9 & 1.5 & 1.8 & 0.4 & -0.9 & -0.1 & 0.5 \\
\hline & \multicolumn{7}{|c|}{ (In percent of exports of goods and nonfactor services) } \\
\hline Debt service due (incl. to the Fund) after debt relief $7 /$ & 11.6 & 10.4 & 7.6 & 2.9 & 3.0 & 5.0 & 5.2 \\
\hline Debt service due (incl. to the Fund) before debt relief & 43.1 & 38.6 & 28.2 & 19.0 & 21.4 & 21.7 & 20.0 \\
\hline Net present value of debt-to-exports ratio $8 / 9 /$ & 120.7 & 153.3 & 144.7 & 137.8 & 140.2 & 146.6 & 145.3 \\
\hline & & (In mill & f U.S. doll & less other & indicated & & \\
\hline Memorandum items: & & & & & & & \\
\hline External current account balance, excluding & & & & & & & \\
\hline official transfers & -249.8 & -185.2 & -157.5 & -122.9 & -142.2 & -134.8 & -110.1 \\
\hline Gross international reserves & 90.7 & 81.9 & 111.9 & 141.9 & 181.9 & 221.9 & 251.9 \\
\hline (in months of imports) 10 / & 2.2 & 2.0 & 2.6 & 3.2 & 3.9 & 4.5 & 5.1 \\
\hline GDP (billions of leones) & $2,085.0$ & $2,854.5$ & $3,338.7$ & $3,775.3$ & $4,212.2$ & $4,638.3$ & $5,079.5$ \\
\hline GDP (millions of U.S. dollars) & 967.1 & $1,043.7$ & $1,160.1$ & $1,263.3$ & $1,371.3$ & $1,483.8$ & $1,601.4$ \\
\hline
\end{tabular}

Sources: Sierra Leonean authorities; and staff estimates and projections.

1/ As in Country Report No. 04/49, Ratios as percent of nominal GDP reflect revised national gross domestic product data.

2/ Based on the trend in growth of real GDP, nominal GDP is not expected to reach the prewar 1996 level of US\$941.7 million until 2005.

3/ Changes as a percentage of beginning-of-period money stock (including foreign currency deposits).

4/ Treasury bill rate (end of period); in percent.

5/ Includes imports purchased with bilateral aid, those related to rehabilitation and reconstruction programs, and imports of embassies and the UN peacekeeping force (UNAMSIL).

6/ Domestic revenue minus total expenditure and net lending, excluding interest payments, and externally financed capital expenditure and disarmament,

demobilization, and reintegration (DDR) program.

7/ As percent of exports of goods and services; after Naples (2001) and Cologne flow reschedulings (2002-04), and delivery of possible HIPC initiative assistance.

8/ Net present value (NPV) of debt relative to backward-looking three-year average of exports of goods and services.

9/ Assumed unconditional delivery of enhanced HIPC initiative assistance in 2000.

10/ In months of imports of goods and services of subsequent year. 
Table 6. Sierra Leone: Status of HIPC Initiative Completion Point Triggers

Triggers
PRSP. Preparation of a full PRSP and implementation for at least one
year, as evidenced by the satisfactory joint staff assessment of the
PRSP and the country's annual progress report.
Macroeconomic stability. Continued maintenance of macroeconomic
stability, as evidenced by satisfactory implementation of the PRGF-
supported program.
Use of budgetary savings. The budgetary savings from interim debt-
service relief in 2002 have been used in the priority areas indicated in
Table 2 of the enhanced Initiative for Heavily Indebted Poor Countries
- Decision Point Document (www.imf.org) and monitored in the
framework for poverty reduction expenditures. The increase in total
spending on these priorities will be proportionate to HIPC relief.
Budgetary savings from interim debt-service relief in subsequent years
will be used in accordance with the agreed annual budgets for those
years.
Governance and decentralization of government functions:
- Completion of disarmament and demobilization and provision of
reintegration assistance to all ex-combatants under the DDR program.
- Biannual tracking of public expenditures on priority areas within
the PETS framework, including development expenditures,
dissemination and publication of results.

- Adoption and implementation of the MTEF, and budget system for tracking expenditures at the regional levels.

\section{Structural measures: \\ - New privatization legislation was introduced in September 2002 for the establishment of an independent National Privatization Commission (NCP) to implement the government divestiture strategy.}

- Adoption by the government of a revised mining policy to promote formal activity (including artisan mining) and attract private investment for medium-and large-scale mining.

\section{Education:}

- The primary gross enrollment rates for girls will have been increased to at least 65 percent.

- At least 1,500 unqualified teachers will have received formal inservice training in primary schools, and at least 500 unqualified teachers will have received in-service training in secondary schools. Health:

- Distribution of insecticide-treated bed nets will have increased from 18,482 in 2000 to 60,000 .

- At least 200 persons, including health professionals and staff from line ministries and civil society organizations, will have been provided by the National HIV/AIDS Secretariat with HIV/AIDS, and STIs education and training on prevention and basic care, in order to encourage HIV/AIDS, and STIs avoidance behavior, destigmatize the disease, and support those infected or otherwise affected by the disease.

- Immunization coverage (percentage of children aged 12 to 23 months immunized against diphtheria, pertussis, and tetanus) will have increased to at least 55 percent.

\section{Status}

A draft full PRSP has been circulated in August 2004 to solicit comments from development partners before the finalization of the document.

Macroeconomic stability continues to be maintained, as evidenced by satisfactory implementation of the PRGF arrangement.

Utilization of interim HIPC relief in 2003 and beyond will facilitate the required increase in budgetary outlays for pro-poor programs, including the provision of education, health, and reviving agriculture and rural development activities that directly benefit the poor.

- The Government concluded the DDR exercise in February 2004, which benefited over 72,000 ex-combatants.

- Review of the PETS was conducted in March 2003, followed by the development of a generic resource flow model. A Public Expenditure Review (PER) was conducted, by the Government in partnership with its main development partners, in January and completed in June 2004.

- The coverage of the MTEF is being widened within the context of the on-going decentralization programm that is contained in the Local Government Act, 2004. The execution of the fiscal budget, starting from 2005, will be decentralized to line Ministries, Government Departments and Agencies (MDAs) in conformity with the on-going drive for decentralization.

- NCP is fully operating and the strategic plan for the divestiture of 24 public enterprises, by December 2006, is ready for implementation. Study visits have been concluded in all parastatals, of which three key ones are slated for privatization by December 2004.

- Stakeholders' workshop was held in Freetown to review and strategize on a policy for reviving and promoting mining activities, attracting private investment in the mining sector, and controlling the artisanal mining.

- Primary school gross enrollment rates increased to 70.7 percent in 2002/03 school year, with the female gross enrollment in primary school being 42 percent.

- 1,573 unqualified teachers are programmed for training under REBEP, funded jointly by World Bank and AfDB. A training module for unqualified secondary school teachers started in January 2004.

- Preliminary data suggest that 65,000 insecticide-treated bed nets had been distributed by 2003 .

- 14 public sector institutions established HIV/AIDS offices and management team; 6 additional institutions have prepared work plan to address HIV/AIDS among workers and with the support of UNICEF, a two-day workshop was held for journalists on HIV/AIDS reporting. Numerous guidelines have been developed and disseminated to various public institutions pertaining to voluntary confidential counseling and testing, antiretroviral treatment, prevention of mother to child transmission, and monitoring and evaluation. Training has also been provided on sentinel surveillance.

- 52 percent of the children aged 0-5 years have undergone the full cycle of immunization coverage. 
Table 7. Sierra Leone: External Financing Requirements and Sources, 2002-09 (In millions of U.S. dollars)

\begin{tabular}{|c|c|c|c|c|c|c|c|c|}
\hline & $\begin{array}{r}2002 \\
\text { Est. }\end{array}$ & $\begin{array}{l}2003 \\
\text { Proj. }\end{array}$ & $\begin{array}{l}2004 \\
\text { Proj. }\end{array}$ & $\begin{array}{l}2005 \\
\text { Proj. }\end{array}$ & $\begin{array}{l}2006 \\
\text { Proj. }\end{array}$ & $\begin{array}{l}2007 \\
\text { Proj. }\end{array}$ & $\begin{array}{l}2008 \\
\text { Proj. }\end{array}$ & $\begin{array}{l}2009 \\
\text { Proj. }\end{array}$ \\
\hline $\begin{array}{l}\text { Current account } \\
\text { (excluding interest and official transfers) }\end{array}$ & -87.2 & -117.0 & -163.7 & -133.0 & -97.1 & -118.5 & -111.6 & -87.4 \\
\hline Debt-service obligations (before relief) & 80.7 & 94.9 & 92.0 & 85.7 & 66.6 & 76.4 & 84.7 & 89.3 \\
\hline Interest & 26.3 & 22.8 & 21.5 & 24.6 & 25.7 & 23.7 & 23.2 & 22.7 \\
\hline Amortization & 54.3 & 72.1 & 70.5 & 61.1 & 40.9 & 52.7 & 61.4 & 66.6 \\
\hline Bilateral & 31.8 & 34.5 & 38.0 & 41.1 & 35.1 & 35.5 & 35.4 & 35.6 \\
\hline Multilateral & 44.7 & 54.2 & 49.1 & 38.3 & 28.2 & 39.2 & 47.6 & 51.9 \\
\hline IMF & 32.2 & 35.5 & 24.4 & 9.3 & 5.4 & 16.8 & 24.9 & 28.9 \\
\hline Reduction of arrears $1 /$ & -6.7 & 13.8 & 9.5 & 0.0 & 0.0 & 0.0 & 0.0 & 0.0 \\
\hline Increase in gross reserves & 32.3 & -25.2 & 22.5 & 30.0 & 30.0 & 40.0 & 40.0 & 30.0 \\
\hline Gross financing requirement & -193.5 & -200.5 & -287.8 & -248.7 & -193.8 & -234.9 & -236.2 & -206.7 \\
\hline Identified disbursements & 193.6 & 200.5 & 287.8 & 216.2 & 164.8 & 193.6 & 183.7 & 145.8 \\
\hline Loans for balance of payments support & 76.9 & 35.4 & 70.6 & 36.4 & 15.0 & 15.0 & 15.0 & 15.0 \\
\hline IMF & 36.0 & 19.6 & 41.1 & 20.4 & 0.0 & 0.0 & 0.0 & 0.0 \\
\hline World Bank/IDA & 28.5 & 15.9 & 15.0 & 10.0 & 10.0 & 10.0 & 10.0 & 10.0 \\
\hline African Development Bank & 12.3 & 0.0 & 14.5 & 6.0 & 5.0 & 5.0 & 5.0 & 5.0 \\
\hline Grants & 76.9 & 81.3 & 93.5 & 93.5 & 95.0 & 107.3 & 98.3 & 86.9 \\
\hline Program & 56.2 & 61.6 & 67.4 & 64.5 & 62.9 & 72.2 & 63.2 & 51.9 \\
\hline Of which: HIPC Initiative grants & 35.8 & 45.4 & 35.0 & 27.3 & 21.1 & 30.6 & 29.8 & 29.5 \\
\hline Project & 20.8 & 19.7 & 26.1 & 29.1 & 32.1 & 35.1 & 35.1 & 35.1 \\
\hline Project loans & 25.9 & 32.5 & 58.9 & 43.0 & 41.0 & 38.0 & 33.0 & 33.0 \\
\hline Foreign direct investment $\&$ private sector loans & 1.6 & 21.0 & 55.9 & 33.3 & -6.3 & 13.7 & 17.7 & -9.9 \\
\hline Debt relief 2/ & 23.9 & 49.1 & 41.6 & 35.2 & 35.5 & 35.1 & 35.3 & 36.5 \\
\hline Other capital, including errors and omissions & -11.7 & -18.8 & -32.8 & -25.2 & -15.3 & -15.4 & -15.6 & -15.7 \\
\hline Financing gap 4/ & 0.0 & 0.0 & 0.0 & -32.5 & -28.9 & -41.3 & -52.5 & -60.8 \\
\hline
\end{tabular}

Sources: Sierra Leonean authorities; and staff estimates and projections.

1/ Rescheduling of arrears by the Paris Club; assumes comparable treatment by other creditors, including military contractors.

$2 /$ Include Naples flow rescheduling provided by the Paris Club in October 2001 and additional relief by other creditors,

Cologne flow rescheduling for 2002-04 agreed by the Paris Club at the decision point in February 2002, and

comparable relief by other creditors. For 2001, the amount includes the rescheduling of arrears of \$239.1 million.

3/ Includes capital outflows associated with unrecorded diamond exports, change in trade credit,

and errors and omissions.

4/ After identified disbursements, debt reschedulings, HIPC Initiative assistance, and short-term capital movements.

5 / Currently unidentified financing. 
Table 8. Sierra Leone: Disbursements Under the PRGF Arrangement, 2001-05 (In millions of SDRs)

\begin{tabular}{|c|c|c|}
\hline Date & Disbursement & Subject to: \\
\hline September 2001 & $46.84^{1}$ & Approval of arrangement \\
\hline March 2002 & 9.33 & $\begin{array}{l}\text { First review and performance criteria } \\
\text { (PCs) for end-September } 2001\end{array}$ \\
\hline September 2002 & 18.66 & $\begin{array}{l}\text { Second review and PCs for end- } \\
\text { December } 2001 \text { and PCs for end- } \\
\text { March } 2002\end{array}$ \\
\hline March 2003 & 14.0 & $\begin{array}{l}\text { Third review and PCs for end- } \\
\text { September. } 2002 \text { and PCs for end- } \\
\text { December } 2002\end{array}$ \\
\hline February 2004 & 14.0 & $\begin{array}{l}\text { Fourth review and PCs for end-June } \\
2003\end{array}$ \\
\hline November 2004 & 14.0 & $\begin{array}{l}\text { Fifth review and PCs for end-March } \\
2004\end{array}$ \\
\hline May 2005 & 14.0 & $\begin{array}{l}\text { Sixth review and PCs for end- } \\
\text { December } 2004\end{array}$ \\
\hline
\end{tabular}




\begin{tabular}{|c|c|c|c|c|c|c|c|c|c|}
\hline & 2001 & 2002 & 2003 & 2004 & 2005 & 2006 & 2007 & 2008 & 2009 \\
\hline & & & \multicolumn{7}{|c|}{ Projections } \\
\hline \multicolumn{10}{|l|}{ Fund credit outstanding (end of period) $1 /$} \\
\hline In millions of SDRs & 120.8 & 124.5 & 113.8 & 125.8 & 134.1 & 131.1 & 120.2 & 103.9 & 84.7 \\
\hline In millions of U.S. dollars & 153.8 & 161.3 & 159.1 & 184.6 & 195.9 & 191.9 & 176.4 & 152.5 & 124.4 \\
\hline In percent of quota & 116.5 & 120.1 & 109.7 & 121.3 & 129.3 & 126.4 & 116.0 & 100.2 & 81.7 \\
\hline & \multicolumn{9}{|c|}{ In millions of US dollars } \\
\hline Fund obligations & 78.1 & 32.2 & 35.5 & 24.4 & 9.3 & 5.4 & 16.8 & 24.9 & 28.9 \\
\hline Fund total charges and interests & 2.7 & 0.8 & 0.9 & 0.9 & 1.0 & 1.0 & 0.9 & 0.8 & 0.7 \\
\hline Existing drawings & 2.7 & 0.8 & 0.9 & 0.8 & 0.8 & 0.8 & 0.7 & 0.6 & 0.5 \\
\hline Prospective drawings & 0.0 & 0.0 & 0.0 & 0.1 & 0.2 & 0.2 & 0.2 & 0.2 & 0.2 \\
\hline Fund total repayments/repurchases & 75.4 & 31.4 & 34.6 & 23.5 & 8.3 & 4.5 & 15.9 & 24.0 & 28.1 \\
\hline Existing drawings & 75.4 & 31.4 & 34.6 & 23.5 & 8.3 & 4.5 & 15.9 & 24.0 & 28.1 \\
\hline Prospective drawings & 0.0 & 0.0 & 0.0 & 0.0 & 0.0 & 0.0 & 0.0 & 0.0 & 0.0 \\
\hline \multicolumn{10}{|l|}{ Fund credit outstanding in percent of: } \\
\hline Exports of goods and services & 119.1 & 105.3 & 80.6 & 77.4 & 64.4 & 54.8 & 49.3 & 39.0 & 27.9 \\
\hline Total external debt $2 /$ & 59.6 & 46.0 & 39.0 & 35.6 & 31.6 & 27.5 & 22.5 & 17.5 & 13.2 \\
\hline Gross official reserves & 296.6 & 190.6 & 267.9 & 225.3 & 175.0 & 135.2 & 97.0 & 68.7 & 49.4 \\
\hline \multicolumn{10}{|l|}{ Fund obligations in percent of: } \\
\hline Exports of goods and services & 60.5 & 21.0 & 18.0 & 10.2 & 3.1 & 1.6 & 4.7 & 6.4 & 6.5 \\
\hline External debt service 2/ & 70.4 & 39.9 & 37.4 & 26.5 & 10.8 & 8.2 & 22.0 & 29.4 & 32.3 \\
\hline Gross international reserves & 150.6 & 38.1 & 59.8 & 29.8 & 8.3 & 3.8 & 9.2 & 11.2 & 11.5 \\
\hline \multicolumn{10}{|l|}{ Memorandum items: } \\
\hline Exports of goods and services (in millions of U.S. dollars) & 129.1 & 153.2 & 197.3 & 238.4 & 304.0 & 350.0 & 357.6 & 391.0 & 446.1 \\
\hline Gross official reserves (in months of imports of goods and services) & 1.9 & 2.5 & 1.5 & 2.0 & 2.6 & 3.2 & 3.9 & 4.5 & 5.1 \\
\hline
\end{tabular}

Sources: Sierra Leonean authorities; and Fund staff estimates and projections.

1/ All numbers are before HIPC Initiative assistance.

2/ Before rescheduling. 


\begin{tabular}{|c|c|c|c|c|c|c|c|}
\hline & \multirow{2}{*}{$\begin{array}{l}2000 \\
\text { Act. }\end{array}$} & \multirow{2}{*}{$\begin{array}{l}2001 \\
\text { Act. }\end{array}$} & \multirow{2}{*}{$\begin{array}{l}2002 \\
\text { Act. }\end{array}$} & \multirow{2}{*}{$\begin{array}{l}2003 \\
\text { Act. }\end{array}$} & \multicolumn{3}{|c|}{2004} \\
\hline & & & & & Budget & $\begin{array}{l}\text { Quarter 1 } \\
\text { Act. }\end{array}$ & $\begin{array}{l}\text { Quarter } 2 \\
\text { Act. }\end{array}$ \\
\hline Total poverty-targeted expenditure & $49,206.5$ & $72,832.5$ & $120,555.1$ & $140,158.0$ & $173,754.5$ & $54,936.7$ & $48,931.5$ \\
\hline Recurrent poverty-targeted expenditure & $49,206.5$ & $69,840.5$ & $108,193.4$ & $120,834.4$ & $157,057.5$ & $49,684.9$ & $42,622.2$ \\
\hline \multicolumn{8}{|l|}{ General services } \\
\hline Ministry of Local Government and Community Development & & $\ldots$ & $\ldots$ & $\ldots$ & $1,209.0$ & 302.2 & 302.2 \\
\hline Security services & $7,677.4$ & $15,450.5$ & $15,272.2$ & $26,158.5$ & $28,611.7$ & $9,449.9$ & $6,387.3$ \\
\hline Police & $5,787.8$ & $10,815.6$ & $10,278.9$ & $16,275.9$ & $17,154.0$ & $4,288.5$ & $4,288.5$ \\
\hline Prisons Department & $1,532.6$ & $3,969.1$ & $4,588.6$ & $5,237.0$ & $6,817.8$ & $1,704.4$ & $1,704.4$ \\
\hline National Fire Authority & 357.0 & 665.8 & 404.7 & $4,645.5$ & $4,639.9$ & $3,456.9$ & 394.3 \\
\hline Social services & $38,909.0$ & $45,802.5$ & $73,955.6$ & $75,783.1$ & $101,402.6$ & $28,099.2$ & $27,599.1$ \\
\hline Ministry of Education, Science and Technology & $28,255.9$ & $29,014.9$ & $44,096.8$ & $43,089.9$ & $54,525.3$ & $15,254.9$ & $14,754.8$ \\
\hline Ministry of Health and Sanitation & $10,125.7$ & $15,573.9$ & $27,366.4$ & $29,962.0$ & $36,643.3$ & $9,160.8$ & $9,160.8$ \\
\hline Ministry of Social Welfare, Gender and Children's Affairs (Social Welfare Division) & 422.9 & 811.5 & 886.5 & $1,097.0$ & $1,357.8$ & 339.5 & 339.5 \\
\hline Gender and Children's Affairs Division & 104.5 & 402.2 & $1,605.9$ & $1,634.2$ & $1,659.4$ & 414.9 & 414.9 \\
\hline Ministry of Youth and Sports & $\ldots$ & $\ldots$ & $\ldots$ & ... & $2,716.6$ & 679.2 & 679.2 \\
\hline Socially-oriented projects & $\ldots$ & $\ldots$ & $\ldots$ & $\ldots$ & $4,500.0$ & $2,250.0$ & $2,250.0$ \\
\hline Economic services & $2,620.1$ & $8,587.5$ & $18,965.6$ & $18,892.8$ & $25,834.3$ & $11,833.6$ & $8,333.6$ \\
\hline Ministry of Agriculture and Food Security & $1,225.8$ & $1,988.5$ & $4,230.5$ & $8,835.7$ & $14,740.6$ & $8,685.2$ & $4,685.2$ \\
\hline Ministry of Transport and Communications & 127.5 & $3,880.0$ & $3,252.0$ & $2,182.6$ & $2,015.9$ & 504.0 & 504.0 \\
\hline Ministry of Energy and Power & $1,266.8$ & $2,719.0$ & $2,929.4$ & $3,602.7$ & $4,077.7$ & $1,019.4$ & $1,019.4$ \\
\hline Domestic debt payback program & & & $8,553.7$ & $4,271.9$ & $5,000.0$ & $1,625.0$ & $2,125.0$ \\
\hline Development poverty-targeted expenditure & $\ldots$ & $2,992.0$ & $12,361.7$ & $19,323.6$ & $16,697.0$ & $5,251.7$ & $6,309.2$ \\
\hline General services & $\ldots$ & $2,442.0$ & $2,379.5$ & $1,076.9$ & $1,970.0$ & 767.5 & 867.5 \\
\hline Ministry of Rural Development and Local Government & $\ldots$ & $2,442.0$ & $2,379.5$ & $1,076.9$ & $1,900.0$ & 750.0 & 850.0 \\
\hline Office of the President & $\ldots$ & $\ldots$ & $\ldots$ & $\ldots$ & 70.0 & 17.5 & 17.5 \\
\hline Security services & & & & $1,038.7$ & 200.0 & 100.0 & 50.0 \\
\hline Prison Department & $\ldots$ & $\ldots$ & 179.8 & 914.7 & 200.0 & 100.0 & 50.0 \\
\hline Fire Force Authority & $\ldots$ & $\ldots$ & $\ldots$ & 124.0 & 0.0 & 0.0 & 0.0 \\
\hline Social services & $\ldots$ & 550.0 & $3,947.5$ & $9,267.4$ & $5,977.0$ & $1,481.7$ & $1,864.2$ \\
\hline Ministry of Education, Youth and Sport & $\ldots$ & 350.0 & 3,688.7 & $4,558.1$ & $1,660.0$ & 415.0 & 447.5 \\
\hline Ministry of Health and Sanitation & $\ldots$ & $\ldots$ & 162.8 & $4,393.3$ & $1,560.0$ & 390.0 & 690.0 \\
\hline Ministry of Social Welfare, Gender and Children Affairs & $\ldots$ & 200.0 & 96.0 & 316.0 & 50.0 & 0.0 & 12.5 \\
\hline National Commission for Social Action (NaCSA) & $\ldots$ & $\ldots$ & $\ldots$ & $\ldots$ & $2,707.0$ & 676.8 & 714.3 \\
\hline Economic services & $\ldots$ & $\ldots$ & $6,034.7$ & $7,940.7$ & $8,550.0$ & 2.902 .5 & $3,527.5$ \\
\hline Minisstry of Agriculture and Food Security & & $\ldots$ & $2,788.0$ & $2,190.1$ & $1,970.0$ & 972.5 & 972.5 \\
\hline Ministry of Marine Resources & $\ldots$ & $\ldots$ & 449.7 & 970.5 & 250.0 & 62.5 & 0.0 \\
\hline Ministry of Energy and Power & & $\ldots$ & $\ldots$ & 272.9 & $1,000.0$ & 250.0 & 250.0 \\
\hline Ministry of Works, Housing and Technical Maintenance & $\ldots$ & $\ldots$ & $2,797.0$ & $4,507.1$ & $5,330.0$ & $1,617.5$ & $2,305.0$ \\
\hline
\end{tabular}

Source: Budget Bureau, Ministry of Finance. 
Table 11. Sierra Leone: Selected Social and Demographic Indicators

\begin{tabular}{|c|c|c|}
\hline & Sierra Leone & Sub-Saharan Africa \\
\hline Total land area (thousands of square kilometers) & 72.3 & $23,628.4$ \\
\hline Agricultural land (in percent of total) & 74 & 53 \\
\hline \multicolumn{3}{|c|}{ Population and vital statistics (2002, unless otherwise indicated) } \\
\hline Total population (in millions) & 4.8 & 643.8 \\
\hline Population growth rate (in percent) & 2.6 & 2.7 \\
\hline Urban population (in percent of total) & 38.1 & 34.0 \\
\hline Population density (per square kilometer; 1999) & 65.0 & 26.6 \\
\hline \multicolumn{3}{|l|}{ Population age structure (in percent; 2002) } \\
\hline $0-14$ years & 44.2 & 44.5 \\
\hline $15-64$ years & 52.9 & 52.6 \\
\hline 65 years and above & 2.9 & 2.9 \\
\hline Infant mortality rate (per thousand; 2002) & 165.0 & 107.0 \\
\hline Life expectancy at birth (years; 2002) & 34.3 & 46.1 \\
\hline Male & 33.1 & 46.0 \\
\hline Female & 35.6 & 48.0 \\
\hline GDP per capita (PPP U.S. dollars; 2002) & 520 & 1,790 \\
\hline Poverty rate (in percent; 2004) $1 /$ & 70.2 & $\cdots$ \\
\hline \multicolumn{3}{|c|}{ Health and nutrition (2000, unless otherwise indicated) } \\
\hline \multicolumn{3}{|l|}{ Access to safe water (in percent of population; 2002) } \\
\hline Total & 57.0 & 46.0 \\
\hline Urban 2/ & 74.0 & 64.0 \\
\hline Rural 2/ & 46.0 & 29.0 \\
\hline Population per physician & $20,695.0$ & $14,347.0$ \\
\hline Population per hospital bed & $\ldots$ & $1,310.0$ \\
\hline Daily per capita calorie supply (2000) & $2,035.0$ & $\ldots$ \\
\hline Percent of requirement & 85.0 & $\ldots$ \\
\hline Protein intake per capita (grams per day; 1990) & 44.0 & $\ldots$ \\
\hline Total labor force (in millions; 1999) & 2.9 & 275.0 \\
\hline \multicolumn{3}{|l|}{ Percent of formal labor force (1997) } \\
\hline Female & 31.5 & 42.2 \\
\hline Agriculture & 60.8 & 70.0 \\
\hline Industry & 17.1 & 8.0 \\
\hline Services & 22.1 & $\ldots$ \\
\hline \multicolumn{3}{|l|}{ Education (2002/2003) } \\
\hline \multicolumn{3}{|l|}{ Percent of age group enrolled in: } \\
\hline Primary school & 90.4 & 78.0 \\
\hline Secondary school & 40.9 & 26.6 \\
\hline Tertiary education & $\ldots$ & 3.4 \\
\hline Adult literacy rate (in percent; 2002) & 36.0 & 40.5 \\
\hline
\end{tabular}

Sources: Statistics Sierra Leone; draft Sierra Leone 2000 "National Human Development and Related Indicators";

UNDP, Human Development Indicators, 2001; UNDP, Human Development Report, 2004; Government of Sierra Leone,

"Household Survey Report on Women and Children 2000"; Sierra Leone Integrated Household Survey (SLIHS) 2003/2004.

$1 /$ This figure is for 2004 from SLIHS. It measures the percentage of the total population whose expenditure on food and basic needs is below Le 2,111 par day (the national poverty line).

2/ MICS 2000 Survey. 
Mr. Rodrigo de Rato

Managing Director

International Monetary Fund

Washington, D.C. 20431

U.S.A.

Dear Mr. de Rato:

1. In accordance with the provisions of the three-year arrangement (approved on September 26, 2001) under the Poverty Reduction and Growth Facility (PRGF), the government of Sierra Leone, in cooperation with staff of the IMF, has evaluated the implementation of the program to end-March 2004, and performance through end-June 2004. The attached memorandum of economic and financial policies (MEFP) highlights recent economic developments and performance during 2003 and the first quarter of 2004, and sets out the government's macroeconomic objectives and policies and the structural reform agenda for the remainder of 2004.

2. Economic activity remained robust in 2003 and has continued at a solid pace this year, reflecting expansions in agriculture, mining, and the services. Progress in enhancing domestic security and the success in maintaining political and economic stability have bolstered confidence. However, inflation has accelerated, in part owing to external factors. The government expects the pace of economic expansion to continue strengthening in the medium term, particularly as new mining projects are brought on line, and as confidence in the economy improves. The government will work to ensure that economic expansion, key to addressing the poverty problem, is undertaken while maintaining macroeconomic stability.

3. Performance under the PRGF-supported program at end-March 2004 was mixed. The government met all quantitative performance criteria except on net bank credit to the central government, owing to the nondisbursement of external program support. The scaling down of government expenditures proved inadequate to limit government bank borrowing. While progress was made in implementing program structural measures, two structural performance criteria were missed. The reconciliation of fiscal and monetary data for 2000-02 was not completed by the end-May 2004 deadline, reflecting delays in the provision of STA technical assistance. In addition, the issuance of new personnel management regulations for the civil service, expected to be effected by end-May 2004, was delayed pending the finalization of a compensation scheme for the senior executive service (SES); however, the implementation of SES has now been further delayed due to the need to first clarify its financing. Therefore, the government has decided to issue new personnel management regulations for existing civil service by mid-October, 2004. Once the SES scheme takes effect, personnel management regulations will be amended accordingly. The government of Sierra Leone has also taken other measures to address the shortcomings and to bring performance during the second half of 2004 broadly in line with the original program. 
4. In view of the above, the government of Sierra Leone requests for waivers on the nonobservance of the end-March 2004 quantitative performance criterion relating to net domestic bank credit to the government and on the nonobservance of the structural performance criteria related to the completion of the reconciliation of fiscal and monetary data for 2000-02 and the issuance of new personnel management regulations for the civil service. The government requests for the completion of the fifth review and the disbursement of the eight loan under the PRGF arrangement in an amount equivalent to SDR 14 million (13.5 percent of quota).

5. The government believes that the policies set forth in the attached MEFP are adequate to achieve the objectives of its program, but will take any further measures that may become appropriate for this purpose. Sierra Leone will consult with the Fund on the adoption of these measures, and in advance of revisions to the policies contained in the MEFP, in accordance with the Fund's policies on such consultation. The government is continuing to address medium-term development issues, and has completed the first draft of a full PRSP that has also been discussed with key stakeholders. The quantitative and structural performance criteria for the sixth review, and quarterly indicative targets through end-2004, are set out in Tables 2 and 4 of the MEFP.

6. The fifth program review was held up by the delay in securing external financing that was critical to the program. Upon the closing of the program financing gap, new understandings were reached on the phasing of, and conditions for, the ninth disbursement, which is proposed to be subject to end-December 2004 quantitative performance criteria, an end-November structural performance criterion, structural benchmarks through endDecember, and a sixth program review, scheduled to be completed by end-May 2005. Given the timing of the completion of the fifth review, the government would like to also request a three-month extension of the arrangement from the current expiration date of March 25, 2005.

7. The government authorizes the publication of this letter and the attached MEFP by the Fund, including the posting of such documents to the IMF website, subsequent to Executive Board approval.

Yours sincerely,

$/ \mathrm{s} / /$

Joseph B. Dauda

Minister of Finance

Freetown, Sierra Leone

Attachments (2)

Memorandum of Economic and Financial Policies for 2004

Technical Memorandum of Understanding 


\section{Memorandum of ECONOMic and Financial Policies OF THE GOVERNMENT OF SIERRA LEONE FOR APRIL 1-DECEMBER 31, 2004 VII. INTRODUCTION}

1. Progress continued to be made in strengthening peace and security in Sierra Leone. The disarmament, demobilization, and reintegration (DDR) program was completed in February 2004, and improved security in neighboring Liberia is further enhancing stability. The withdrawal of the United Nations forces in Sierra Leone (UNAMSIL), originally scheduled for end-2004, has been delayed by the UN Security Council, maintaining a reduced UNAMSIL presence until mid-2005, to allow more time for strengthening domestic armed and police forces.

2. Local government elections were held in May 2004. A decentralization plan and timetable is being developed by the government. The Ministry of Finance is identifying budgetary resources (for the 2005 budget) from line ministries for the devolved functions, including primary education and primary health car. The total budgetary provisions for these programs will be distributed to all regional and city councils using a grants distribution formula, which reflects the relative needs of each council. Additional fiscal implications are likely, given the need to strengthen ministries for carrying out their new functions of policy formulation, monitoring and supervision.

3. Improved security and the decentralization of government are having a positive impact on the environment in which the government's growth and poverty reduction policies are being implemented.

4. This memorandum of economic and financial policies (MEFP) supplements the one issued in February 2004. It describes recent developments and performance under the program, and outlines government's macroeconomic objectives and policies for the remainder of 2004.

VIII. Recent Developments And Performance Under the Program

5. Output growth was strong in 2003, reflecting robust agricultural, mining, and manufacturing operations, but the economy also experienced a sharp increase in consumer prices. Real output is estimated to have increased by 9.3 percent. Statistics Sierra Leone has now received detailed returns on outturns for 2001 and 2002 and has revised GDP growth rates for these years. Given the stronger than the earlier estimated performance in agriculture, real GDP growth for 2001 is now put at 18 percent, compared to the original 5.4 percent, while it is revised to 27.5 percent from 6.6 percent in 2002. Annual average inflation rose to 8.2 percent, resulting initially from higher fuel costs but expansionary monetary policy, partly owing to delays in donor support, and a depreciation of the currency towards the end of the year also fueled inflation. Year-on year inflation accelerated from 11.3 percent at end December 2003 to 14.6 percent at end-June 2004. 
6. Fiscal performance in 2003 was somewhat weaker than envisioned, largely due to overruns related to domestic outlays. While domestic revenue collection was stronger and total expenditures were only marginally higher than projected, mainly reflecting higher wage and nondefense expenditures (the latter included poverty-related outlays that exceeded the programmed level by 0.1 percent of GDP), a shortfall in external program grants and loans, vis-à-vis the original program, led to large domestic financing of the budget, especially from the banking system.

7. Fiscal pressures continued in the first quarter of 2004. The government scaled down its expenditure outlays mainly in response to the 3.4 percent of GDP shortfall in nonHIPC external program grants and loans, but in the event domestic bank and nonbank financing of the budget was larger than programmed. Non-interest current expenditures were below the programmed level (this included lower than programmed social and povertyrelated outlays), whereas domestic interest outlays, in part reflecting the higher cost of borrowing, and the repayment of domestic supplier and wage arrears were higher than originally programmed.

8. Poverty-related expenditures were constrained by delays in the issuance of new procurement guidelines in line with the ongoing reforms in procurement policy. The delays resulted in a large backlog in processing contract awards and, hence, effected payments. For end-March 2004, actual expenditure for poverty-related outlays was Le 29 billion compared to a projected amount of Le 55 billion, as significant under spending occurred in the health sector. Domestic interest expenditures exceeded programmed levels in the first quarter of 2004 reflecting higher domestic bank borrowing and the higher interest rates on government securities.

9. Broad and reserve money growth rates in 2003 were higher than projected, mainly due to expansion of credit to the government and the private sector. Growth in both magnitudes continued at a rapid pace in the first quarter of 2004. Interest rates on threemonth Treasury bills rose to $26 \frac{1}{2}$ percent in March 2004, reflecting inflationary pressures and large domestic borrowing of the government, while bank-lending rates remained unchanged at 20 percent, after adjusting for inflation, the rates stood at 14 and 8 percent respectively. Private sector credit expanded strongly in the first quarter, continuing the pace experienced in 2003. This rapid expansion (from a relatively low base) is in part explained by sustained high activity levels, notably in construction, manufacturing, and services.

10. The external current account deficit, excluding official transfers, widened in 2003 to 14.1 percent of GDP, from 12.1 percent in 2002. However, this was less than programmed and reflected delays in rehabilitating the Rutile mining operations. While export performance during the year improved significantly, particularly for diamonds, import needs remained at a high level due to continued expansion in reconstruction activities and high oil prices. Gross official reserves fell to 1.5 months of imports (US\$60 million at end-2003), and remained at about the same level by end of first quarter in 2004 . 
11. Partly due to delays in external donor assistance during the year, the government missed a number of indicative performance targets at end-2003. The indicative ceilings on net domestic bank credit to the government, and on net domestic assets of the Bank Sierra Leone (BSL), as well as the floor on domestic primary budget balance were missed. The ceiling on the government's wage bill was also missed, in part due to the earlier underestimation of pension and related social security expenditures as well as the depreciation of the exchange rate that affected salary payments to foreign missions. All other indicative program targets were met, including the floors on government domestic revenues and poverty-related outlays.

12. All quantitative performance criteria for the eight disbursement under the PRGF arrangement have been met, except for the ceiling on net bank credit to the government, in part owing also to the unexpected shortfall in program grants and loans (mainly, from the African Development Bank (AfDB)), which was disbursed in April 2004, and from the European Union (EU)). The end-March 2004 indicative program targets for floors on total domestic government revenue and poverty-related expenditures were also missed. On the revenues, there was some diversion of taxable activities through Liberia following the beginning of the peaceful political transition in that country. As mentioned above, the implementation of new procurement procedures delayed procurement in the social sectors resulting in lower-than-projected expenditures.

13. All structural performance criteria subject to the fifth review under the program have been met, with the exception of the reconciliation of fiscal and monetary data for 200002 , and the issuance of new personnel management regulations. The exercise to reconcile fiscal and monetary data will not be completed by the end-May 2004 deadline, reflecting delays in the provision of IMF technical assistance. The issuance of new personnel management regulations was delayed to allow the incorporation of the proposed new structure for top civil servants - the senior executive service (SES) — into the guidelines. Guidelines requiring double signature in operating school bank accounts were issued in February 2004. However, the opening of school accounts has been slow as only 30 percent of schools were operating bank accounts as at end June 2004. The aim now is to double the proportion to 60 percent by end-2004. Identification cards were issued by mid-March for the remaining twenty percent of all verified teachers.

14. Progress has also been made in completing the benchmarks under the program. With regard to the specific measures to strengthen the Auditor General's Office, additional professional and managerial staff has been hired to expedite the audits of government ministries and agencies. Employment ceilings for individual schools have been established and published in the government gazette. The Establishment Secretary's Office (ESO) database of civil servants and teachers is being updated monthly and used to update the payroll data of the Accounting General's Office. Equipment has been acquired to support efforts for making the photo verification system for civil servants and teachers in the ESO fully operational, and seven new staff have been hired. An action plan has been formulated to implement recommendations of the financial audit of the Ministry of Education. The amendments to the Income Tax Act, Sales Tax Act, and Customs Act to ensure consistency 
with the National Revenue Authority Act are proceeding with the assistance of the Commonwealth Secretariat and will be completed by mid-2005. Plans to convert the ESO into a personnel management office is under way, and are being supported by the U.K. Department for International Development (DfID). On the issuance of identification cards for all civil servants, the software to handle the data has been obtained, and the process will conclude by end-December 2004. The Fund provided, in April 2004, technical assistance for developing a medium-term budgetary framework that would incorporate all major mineral revenues. The medium-term budget will systematically incorporate these revenues beginning in 2005. On the securitization of all remaining verified domestic arrears, the government has examined various options and decided to pay smaller creditors directly. The remaining Le 20 billion owed to a single creditor has continued to raise legal and other questions which the government will examine, and communicate its final stand to the claimant by endSeptember 2004. Finally, diagnostic studies related to six key ministries have been completed, and Cabinet has approved action plans on three of those. The remaining three are at various stages of review and approval. Under phase 2 of the Governance Reform Project funded by DfID, diagnostic studies on the remaining government ministries will be conducted over a period of three years.

15. The third public expenditure tracking survey (PETS) for FY 2002 was conducted in October 2003 to effectively track the flow of public funds. The October 2003 survey traced the flow of school fees subsidy, teaching and learning materials and essential drugs from the central government to schools and health units, for financial year 2002. The report was issued in July 2004. The survey identified significant transfer discrepancies in the flow of essential drugs from the headquarters to health facilities. Similarly, transfer discrepancies were discovered in the flow of teaching and learning materials. The survey also revealed that the payment of school fees subsidies to primary schools improved significantly when an auditing firm, KPMG, was contracted to undertake the payments.

16. The IMF and the World Bank conducted a HIPC Expenditure Tracking Survey (AAP) in January 2004. Sixteen key indicators were reviewed and benchmarks set for each indicator. The assessment shows that the country met 7 out of the 16 Public Expenditure Management (PEM) benchmarks in 2003. An action plan has been prepared to strengthen PEM. With the coordinated assistance of the major donors active in PEM, adequate technical assistance is being provided to support the implementation of the action plan. ${ }^{37}$

17. Interim procurement rules and regulations were approved by Cabinet in June 2004 and were made effective immediately. A public procurement board to review procurement cases has been set up. The drafting of a comprehensive procurement law commenced in June 2004, and a technical working group has been established by to review recommendations of

${ }^{37}$ The IMF has introduced a regional public expenditure management advisor, based in Accra, Ghana, to cover Sierra Leone, among other countries. This expert will focus primarily on the issues identified in the HIPC AAP report. 
the consultant drafting the law. A national consultative workshop was held in August 2004. The draft law will then be submitted to Cabinet for approval and subsequently to Parliament for enactment.

18. On the preparation of a full poverty reduction strategy paper (PRSP), a first complete draft was finalized in August. A series of consultations with key stakeholders were undertaken in 2004, leading to policy matrices based on four sets of policy pillars. Quantitative and qualitative poverty analyses have been carried out (partly based on a household survey finalized in early 2004) and a poverty profile (including a poverty line) has been established. Sector reviews were concluded in June. The complete draft is scheduled to be discussed with domestic shareholders and development partners in August/September, to be followed shortly after that by the finalization of the paper.

19. In order to strengthen the fight against corruption, a review of the organization and activities of the Anti-Corruption Commission was completed in 2002, with several recommendations made for strengthening the commission, including capacity building, strategic planning, staff rationalization, pay enhancement, and other improvements in the conditions of service. Since March 2004, the Commission has been implementing these recommendations. Furthermore, the prosecution of alleged corruption cases is being expedited by the arrival of two judges from the United Kingdom while on the investigative side, the relevant department of the commission is being strengthened by the recruitment, by DfID, of two principal investigators and a senior investigator.

20. A number of projects are currently under way to speed up the privatization of state enterprises. In the financial sector, a financial advisor would be selected soon to lead the privatization of the National Development Bank (fully government-owned) and the Rokel Commercial Bank (majority government-owned). A consultant is being hired to set up the regulatory agency for the energy sector. A consulting firm, PKF, has submitted a report to the government for the privatization of the non-core activities of the ports, namely, port services, ferry services, slipway and clinic. In addition, the terms of reference have been prepared for the consultant to undertake a study on the core activities. A joint venture company has been established to transform the National Workshop into an economic and trade zone; construction work has already commenced. The UNDP has provided funding for the evaluation of the assets of the Forestry Industries and KPMG has been appointed to undertake the study.

21. In November 2003, the government cleared all outstanding arrears to the National Power Authority (NPA) through a settlement of cross debt liabilities, which resulted in the net debt of Le 6.4 billion due from the government (paid in cash). In addition, several measures have been implemented to prevent the reoccurrence of arrears, including priority payment for utility bills by ministries out of departmental expenditure outlays. Government has also mandated the utility companies to disconnect ministries in default of payment. However, government has accumulated arrears to the national telephone company (Sierra Tel) and Guma Water Company. A payment plan has been agreed. An amount of Le1 5 billion was paid to the two parastatals during the first half of 2004 . 


\section{ObJectives ANd Policies FOR the Remainder of 2004}

22. The government is assuming growing responsibility for maintaining peace and security, while effecting the decentralization of public administration and related services to local (district) authorities. Increased emphasis will be placed on maintaining macroeconomic stability and reducing poverty. A full PRSP will be finalized in the course of the year and discussed with key domestic stakeholders and development partners.

23. The program for 2004 projects real GDP growth at 7.4 percent, revised upwards from 6.8 percent in the original program (following the revised national accounts), supported mainly by the continued recovery of the agricultural sector and expanded reconstruction and other investment activities. Average annual inflation has also been revised upward in light of the continued rapid rise in the consumer prices. For 2004, inflation is projected to average $13^{1 / 2}$ percent.

\section{A. Fiscal Policy}

24. Fiscal policy will aim at supporting macroeconomic stability. A particular issue relates to the domestic interest bill, which is projected to rise by almost 2 percent of GDP relative to the program, reflecting rising interest rates and higher domestic borrowing. With domestic revenues projected at slightly below the level of the original program (12.2 percent of GDP), domestic non-interest expenditures will have to be contained to provide for the higher interest outlays. The overall fiscal deficit, including grants, will increase from 51/2 percent of GDP to $7 \frac{1}{2}$ percent (at 17 percent excluding grants) while the domestic primary deficit will decline by 2 percentage points to 3 percent of GDP. The government will aim at protecting poverty-related spending. The domestic financing of the budget is expected to rise to about $1 \frac{1}{2}$ percent of GDP in 2004 compared to 0.9 percent in the program, to allow a modest easing on the tight expenditure constraint.

25. Domestic revenues are expected to reach Le 348 billion in 2004, reflecting gains due to higher exchange rate and inflation, as well as improvements in revenue collection efforts. A specific issue concerns the scope for implementing rate reductions for income and corporate taxes (as announced in the 2004 budget); these revenue measures would be expected to amount to about $2 / 3$ of a percent of annual GDP. However, given the very tight fiscal position, the tax rate reductions will be postponed beyond this fiscal year.

26. External budgetary support will be broadly in line with the original program, but uncertainties remain regarding the timing of the disbursement. Domestic financing of the 2004 budget will need to come largely from nonbank sources as envisioned under the program, as net bank credit to the government will have to be curtailed.

27. In respect of mineral taxation, an important milestone was reached in November 2003 with the adoption of the Core Mineral Policy, which defines the broad policy framework for the mineral sector. The next step, envisioned to be completed by mid-2005, will be to amend the 1996 mineral act to make it consistent with the new policy framework, issue relevant regulations, and develop a tax schedule for the mineral sector. All future 
agreements with mining companies will be subsidiary to the revised mineral act. ${ }^{38}$ NRA has undertaken to develop model agreements for the rest of the mineral sector, based on a model agreement for the petroleum sector. In light of the significant revenues that are expected from the mineral sector in coming years, the government has decided to join the Extractive Industries Transparency Initiative (EITI) to ensure maximum transparency in the collection of these revenues. To this end, the government will work with mining companies and the civil society towards the development of revenue reporting templates, which will be reconciled by an independent agent, and published. As a first concrete step in this direction, the government has requested technical assistance from the World Bank. Furthermore, tax incentives have been included in the relevant tax laws, and not in the Investment Code.

28. On the expenditure side, some reductions for the rest of 2004 are planned in critical lines, including security and economic outlays, while, as much as possible, safeguarding poverty-related outlays. In respect of the wage bill, its reporting will be done on an accrual, rather than on cash basis in order to prevent repeated and unanticipated build-up of arrears. The accumulation and payment of wage arrears will be shown separately below the line. Furthermore, the hiring of teachers and other civil servants as well as any increases in salaries would be strictly guided by programmed expenditures.

29. As the international community reduces its intervention in maintaining peace in Sierra Leone, the government will need to increasingly assume its responsibility in this area. By October 2004, the peacekeeping forces, UNAMSIL, would have handed over responsibility for security to the government throughout the country. This will have major implications for security expenditures given the need to equip the security agencies. The implementation of the decentralization process also has fiscal implications since all 19 councils would need to be assisted with initial administrative and related costs.

30. The NRA will be pursuing a broad reform agenda aimed at enhancing the integrity and probity of tax collectors at all levels. To improve tax administration, NRA has decentralized the income tax department through the creation of tax districts and Taxpayer Service Units (TSU) in each district; established a Large Taxpayer Unit (LTU) to improve the management of tax arrears; streamlined the clearing of goods at the port; established Flexible Anti-Smuggling Teams (FAST) to lead the fight against smuggling; developed a strategy for the computerization of tax procedures; and mounted effective publicity and education campaigns to sensitize taxpayers on their obligation. In 2004, the Government will transfer to the NRA the three percent of tax revenues specified in the Act in order to strengthen the institution. The Government Gold and Diamond Evaluation Office has now been fully integrated into the NRA's Income Tax Department to facilitate the collection of the withholding tax for diamond exports. This has also resulted into the regularization of the payment of a 5 percent withholding tax by the independent evaluator of Diamond Council

\footnotetext{
${ }^{38}$ Fund staff will be consulted, in the context of the PRGF-supported program, prior to any commitments to be made in this area.
} 
International. With FAD technical assistance, medium-term revenue forecasts have been proposed for each major mining project. The finalized forecasts will be incorporated in the medium-term revenue framework beginning with the 2005 financial year.

31. The implementation of the Automated System of Customs data (ASYCUDA) for which the U.K. Department for International Development (DfID) has indicated readiness to provide support is in progress. In this regard, technical assistance will be provided to conduct a comparative study of ASYCUDA and Trade Net software to determine which would better the NRA. The African Development Bank has also agreed to support the computerization of the NRA subject to the outcome of an independent needs assessment, specification of appropriate design features and costs.

\section{B. Monetary Policy and Financial Sector Reform}

32. Monetary policy in 2004 will complement fiscal policy to reduce inflation. The BSL will pursue this objective mainly by managing its net domestic assets. Net bank credit to the government will rise only modestly. Broad money is projected to rise by about 18 percent in 2004. To assist in containing money growth and mopping up excess liquidity, the BSL raised the statutory reserve requirement ratio from 10 to 12 percent [the timing needs to be confirmed by the authorities]. The BSL is also exploring the possibility of extending the reserve requirement to foreign currency deposits of commercial banks, and would need technical assistance from the Fund for the purpose. Secondary market trading in T-bills will also soon be introduced. By end-October 2004, the Bank intends to commence securities repurchase agreements (repos) after the necessary preparations have been finalized. Interest rates should also rise as a result of the foregoing measures to moderate the growth of private sector credit.

33. The BSL has worked closely with the MFD on a program of reforms in the key areas of banking supervision and monetary operations. Improvements in monetary operations, together with the development of a secondary market for government securities, will be critical for the BSL's modernization program. In addition, efforts are under way to strengthen the payments system. With the view of safeguarding the stability of the financial system in light of the rapid growth in private sector credit, the BSL is monitoring closely the portfolios of commercial banks to ensure observance of high credit standards.

34. The exchange rate in Sierra Leone will continue to be market-driven, based on BSL's weekly foreign exchange auctions. At end-2003, the special window that had been used by oil companies to purchase foreign exchange was closed.

35. The BSL is implementing the recommendations of the Fund's safeguard assessment mission of 2002, in part to avoid the repetition of the internal check recycling incident discovered in mid-2003. BSL's external auditors have been replaced by a team comprising a local and an internationally reputable audit firm; Parnell Kerr Forsters has been selected to conduct the 2003 audit. The central bank's recordkeeping is also being computerized, with the view to strengthening internal controls. 


\section{External Sector Policies}

36. The current account deficit in 2004, excluding official transfers, is projected at 18 percent of GDP (at 12 percent, including transfers). A significant development on the export side was the opening of the Koidu Kimberlite mine, which is expected to yield US\$19 million in export receipts in 2004. Once the mine reaches full capacity in 2006 with an annual production of about US\$44 million, annual income to the government in form of royalty, free carried interest, and corporate income tax payments could exceed US\$ 5 million. ${ }^{39}$ The government is also currently negotiating a production license for the resumption of bauxite mining, and production could resume in late 2004. The rehabilitation of these mines requires considerable capital imports, which have combined with the increase in oil prices to produce strong growth in the value of projected imports. Over the mediumterm, however, import growth is expected to slow down leading to a considerable improvement in the current account balance.

37. The government has reached debt relief agreements with most of its official creditors, but progress with commercial creditors has to date been limited. Despite efforts to contact creditors with validated claims, and to make goodwill payments to most of them, it has not been possible so far to reach debt relief agreements consistent with the HIPC Initiative and on terms comparable to those granted by the Paris Club. In order to address this situation, the government has decided to request for a second IDA debt buyback operation. It is hoped that this would extinguish most of Sierra Leone's outstanding commercial debt.

38. In respect of fostering regional integration, the government plans to adjust its external tariffs gradually toward the agreed common external tariff (CET) of the Economic Community of West African States (ECOWAS). FAD has provided technical assistance for this purpose. A study has also been initiated to assess the fiscal impact of the change in the tariff regime, and a technical working group has been formed bringing together experts from relevant ministries. A regional conference was held in July 2004 to review the various country impact assessments with a view to adopting an implementation schedule consistent with the 2005 implementation deadline.

\section{Structural Reforms}

39. The program of structural reforms for the period July-December 2004 will focus on three main areas: the management of the school system; the reinforcement of budgetary discipline and transparency; and improvements in the civil service (Attachment I, table 4).

40. In respect of the management of the school system, considerable progress has been made. Further action is, however, needed in effecting payments for salaries and other

${ }^{39}$ An exploration license in the Tonga area has been issued to the company operating the Koidu Kimberlite mine. Should the bulk sampling be successful, a mine on a similar scale to the Koidu mine could be developed. 
transactions through the banking system. In this regard, the government is aiming at increasing the proportion of schools with bank accounts from its current 30 percent to 60 percent at end-December 2004. In the same vein, the government will encourage greater use of the banking system for the payment of salaries to civil servants and teachers through individual bank accounts.

41. The government is continuing to reinforce budgetary discipline and to increase transparency. At a broad level, government is taking action to effect the enactment of the Budgetary and Accountability Act, aimed at streamlining the budgetary process. Additionally, interim guidelines have been adopted to guide government procurement; a comprehensive legislation will be put in place before end-2004. The government has also decided to monitor the wage bill on an accrual basis for each quarter of the year, starting in the first quarter of 2005.

42. Government is continuing to strengthen personnel management and to streamline key ministries. New personnel management regulations for the civil service, establishing a code of ethics, an appraisal system, and a performance-based system, will be issued by midOctober 2004. Diagnostics studies and reforms for key ministries will be finalized by 2005 to assist in streamlining and staffing of these ministries. A senior executive service (SES) within the civil service is planned to be introduced by mid-2005 to improve the management of the key ministries and of governmental major initiatives. The introduction and management of the SES will be made consistent with available fiscal resources.

\section{Program Monitoring and Reviews}

43. The government is requesting waivers for the nonobservance of the structural performance criteria on the reconciliation of fiscal and monetary data, and on the issuance of new personnel management regulations. The first performance criterion was missed because of the delay in IMF technical assistance, while the implementation of the second one was delayed in order to incorporate aspects related to the proposed senior executive service. Furthermore, the government is requesting a waiver on the nonobservance of the quantitative performance criterion at end-March 2004, pertaining to central government net credit from the banking system, owing in part to the shortfall in external program grants and loans. The government has since taken steps, as discussed in section III.A., to address this problem for the remainder of 2004. Given the likely timing of the completion of the fifth review, the government of Sierra Leone requests a three-month extension of the arrangement from the current expiration date of March 25, 2005. The program will continue to be monitored based on quantitative and structural performance criteria and benchmarks indicated in Tables 3 and 4 of this attachment. The sixth and final review of the PRGF arrangement will be completed by end-May 2005, based on end-December 2004 quantitative performance criteria, on end-November 2004 structural performance criterion, and on structural benchmarks through end-December 2004. 
Table 1. Sierra Leone: Quantitative Performance Criteria and Indicative Targets

(Cumulative change from beginning of calendar year to end of month indicated; in millions of leones, unless otherwise indicated) 1

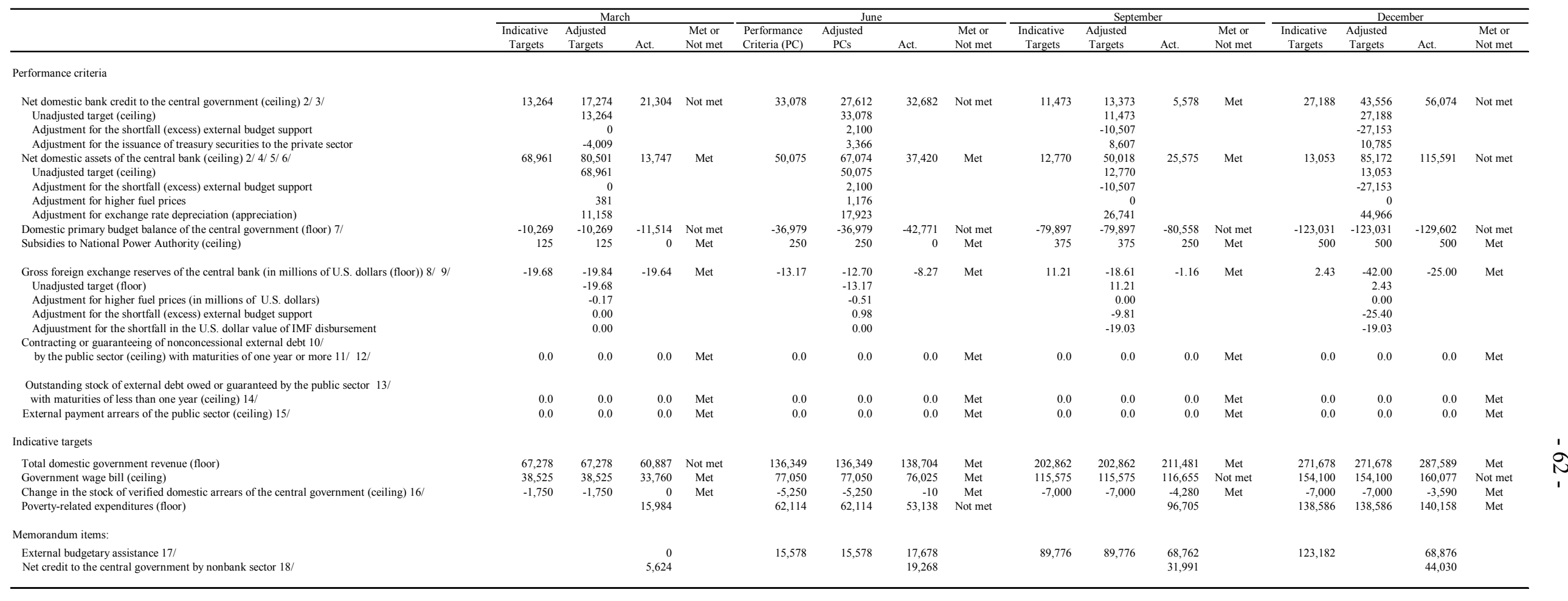

1/ Variables are based on definitions in the technical memorandum of understanding (TMU) of March 2003.

2/ The ceilings will be adjusted downward by the amount of any excess in programmed external budgetary assistance (see footnote 16). The ceiling will also be adjusted upward

by up to 50 percent of the amount of any shortfall in external budgetary assistance (as defined in the TMU; see footnote 16 ).
$3 /$ Defined as claims on government (net) in the monetary survey. To be adjusted downward (upward) by any net issues of government securities to the nonbank private sector

Defined as the difference between the net foreign assets of the central bank (valued at the program exchange rate) and reserve money

6/ The program net domestic assets performance criterion will also be adjusted for higher-than-programmed oil prices with an upside adjustment cap of US\$10 million translated into leones at the actual exchange rate,

as specified in paragraph 31 lof the TMU of March 2003 .
$7 /$ Defined as domestic revenue minus total expenditure and net lending, excluding interest payments, externally financed capital expenditures, and the externally financed DDR program.

9/ The floor will also be adjusted downward for higher-than-programmed oil prices, with a downside adjustment cap of USS10 million, as specified in paragraph 31 of the TMU of March 2003.

10/ This performance criterion applies to debt as defined in Annex 1 of the TMU of March 2003.

12/ Excluded from this performance criterion are external loans with a grant element orivalent to 35 percent or more, calculated using a discount rate

15/ To be applied on a continuous basis. Excluded from this performance criterion are those debts subject to rescheduling arrangements

17 Teling regre is

18/ Comprises treasury bills purchsed by the National Social Security and Insurance Trust (NASSTT) and the nefat grants, and loans. 
Table 2. Sierra Leone: Proposed Quantitative Performance Criteria and Indicative Target

(Cumulative change from beginning of calendar year to end of month indicated; in millions of leones, unless otherwise indicated) 1/

\begin{tabular}{|c|c|c|c|c|c|c|c|c|c|c|}
\hline & \multicolumn{10}{|c|}{2004} \\
\hline & \multicolumn{4}{|c|}{ March } & \multicolumn{4}{|c|}{ June } & \multirow{2}{*}{$\begin{array}{c}\text { September } \\
\text { Indicative } \\
\text { Targets } \\
\end{array}$} & \multirow{2}{*}{$\begin{array}{c}\text { December } \\
\text { Performance } \\
\text { Criteria } \\
\end{array}$} \\
\hline & $\begin{array}{l}\text { Performance } \\
\text { Criteria }\end{array}$ & $\begin{array}{l}\text { Adjusted } \\
\text { PCs }\end{array}$ & Act. & $\begin{array}{c}\text { Met or } \\
\text { Not met }\end{array}$ & $\begin{array}{c}\text { Indicative } \\
\text { Targets }\end{array}$ & $\begin{array}{l}\text { Adjusted } \\
\text { PCs }\end{array}$ & Prel. & $\begin{array}{c}\text { Met or } \\
\text { Not met }\end{array}$ & & \\
\hline \multicolumn{11}{|l|}{ Performance criteria } \\
\hline Net domestic bank credit to the central government (ceiling) 2/3/ & $-25,000$ & 8,898 & 22,197 & Not met & $-5,000$ & 4,026 & 33,176 & Not met & $-2,000$ & $-9,255$ \\
\hline Unadjusted target (ceiling) & & $-25,000$ & & & & $-5,000$ & & & & \\
\hline Adjustment for the shortfall (excess) external budget support & & $-37,908$ & & & & $-31,722$ & & & & \\
\hline Adjustment for the issuance of treasury securities to the private sector & & 4,010 & & & & 22,696 & & & & \\
\hline Net domestic assets of the central bank (ceiling) $2 / 4 / 5 /$ & $-5,000$ & 40,849 & 23,633 & Met & 23,000 & 64,111 & 20,833 & Met & 26,000 & 15,048 \\
\hline Unadjusted target (ceiling) & & $-5,000$ & & & & 23,000 & & & & \\
\hline Adjustment for the shortfall (excess) external budget support & & $-37,908$ & & & & $-31,722$ & & & & \\
\hline Adjustment for exchange rate depreciation (appreciation) & & 7,941 & & & & 9,389 & & & & \\
\hline Domestic primary budget balance of the central government (floor) $6 /$ & $-46,049$ & $-46,049$ & $-25,445$ & Met & $-81,415$ & $-81,415$ & $-51,253$ & Met & $-109,578$ & $-81,361$ \\
\hline Subsidies to National Power Authority (ceiling) & 0.00 & 0.00 & 0.00 & Met & 0.0 & 0.0 & 0.0 & Met & 0.0 & 0.0 \\
\hline Gross foreign exchange reserves of the central bank (in millions of U.S. dollars (floor) ) $7 /$ & 18.31 & -10.85 & 7.90 & Met & 5.67 & -18.73 & 0.40 & Met & 21.7 & 22.5 \\
\hline Unadjusted target (floor) & & 18.31 & & & & 5.67 & & & & \\
\hline Adjustment for the shortfall (excess) external budget support & & -29.16 & & & & -24.40 & & & & \\
\hline Adjuustment for the shortfall in the U.S. dollar value of IMF disbursement & & 0.00 & & & & 0.00 & & & & \\
\hline Contracting or guaranteeing of nonconcessional external debt $8 /$ & & & & & & & & & & \\
\hline by the public sector (ceiling) with maturities of one year or more $9 / 10 /$ & 0.0 & 0.0 & 0.0 & Met & 0.0 & & & & 0.0 & 0.0 \\
\hline $\begin{array}{l}\text { Outstanding stock of external debt owed or guaranteed by the public sector } 11 / \\
\text { with maturities of less than one year (ceiling) } 12 /\end{array}$ & 0.0 & 0.0 & 0.0 & Met & 0.0 & & & & 0.0 & 0.0 \\
\hline External payment arrears of the public sector (ceiling) $13 /$ & 0.0 & 0.0 & 0.0 & Met & 0.0 & & & & 0.0 & 0.0 \\
\hline \multicolumn{11}{|l|}{ Indicative targets } \\
\hline Total domestic government revenue (floor) & 82,642 & 82,642 & 80,025 & Not met & 165,967 & 165,967 & 174,734 & Met & 248,495 & 348,083 \\
\hline Government wage bill (ceiling) & 43,023 & 43,023 & 42,806 & Met & 86,045 & 86,045 & 86,780 & Not met & 129,068 & 173,825 \\
\hline Poverty-related expenditures (floor) & 54,937 & 54,937 & 29,048 & Not met & 102,888 & 102,888 & 68,167 & Not met & 139,573 & 150,522 \\
\hline \multicolumn{11}{|l|}{ Memorandum items: } \\
\hline External budgetary assistance $14 /$ & 75,816 & & 0 & & 103,007 & & 39,562 & & 142,007 & 170,467 \\
\hline Net credit to the central government by nonbank private sector $15 /$ & 556 & & 4,010 & & 11,513 & & 22,696 & & 11,406 & 51,230 \\
\hline
\end{tabular}

1/ Variables are based on definitions in the technical memorandum of understanding (TMU) of December 2003.

2/ The ceilings will be adjusted downward by the amount of any excess in programmed external budgetary assistance (see footnote 16). The ceiling will also be adjusted upward by up to 50 percent of the amount of any shortfall in external budgetary assistance (as defined in the TMU; see footnote 16).

3/ Defined as claims on governite (ne nonbank private sector

up to the ceiling on net domestic bank credit to the central government.

(The program exchange rate as defined in the technical memorandum of understanding (TMU) of December 2003.

5/ Defined as the difference between the net foreign assets of the central bank (valued at the program exchange rate) and reserve money.

.

7/ In the event of an excess (shortall) in external budgetary assistance (as defined above), the floor will be al

8/ This peformance con 2003.

10/ Excluded from this performance criterion are external loans with a grant element equivalent to 35 percent or more, calculated using a discount rate

based on OECD commercial interest reference rates (CIRRs).

11/ The term "debt" has the meaning set forth in Annex 1 of the TMU of December 2003.

11/ The term "debt" has the meaning set forth in Annex 1 of the TMU of Decem

13/ To be applied on a continuous basis. Excluded from this performance criterion are those debts subject to rescheduling arrangements.

rogram grants and program loans.

15/ Comprises treasury bills purchased by the National Social Security and Insurance Trust (NASSIT) and the non-financial private sector. 
Table 3. Sierra Leone: Structural Performance Criteria and Benchmarks for September 2003 - June 2004 Under the Program Supported by the Poverty Reduction and Growth Facility Arrangement

\begin{tabular}{lcc}
\hline Performance Criteria and Structural Benchmarks & Timing & Statu \\
\hline
\end{tabular}

\section{Performance criteria}

Guidelines have been issued by the Ministry of Finance requiring double signatures in operating school bank accounts; one of the signatures to be that of a member of the community-based school management committee.

Identification cards have been issued by Ministry of Finance for the remaining twenty percent of all verified ${ }^{2}$ teachers.

The reconciliation of fiscal and monetary data for 2000-02 has been completed.

New personnel management regulations for the civil service, establishing a code of ethics, and including a system for performance-based appraisal and promotions, have been introduced.

\section{Benchmarks}

Specific measures have been elaborated to strengthen the Auditor General's Office, including the use of private accounting firms to expedite audits of government ministries and agencies.

The photo verification system for civil servants and teachers in the

Establishment Secretary's Office (ESO) is operational and adequately staffed.

Legislation relating to customs and inland revenue has been revised

to ensure consistency with provisions under the National Revenue Authority Act.

Employment ceilings for individual schools have been established,

and these data have been published in the government gazette.

The ESO database of civil servants and teachers is updated monthly and used to update the payroll database of the Accountant General's Office.

Terms and conditions for securitization of all remaining verified domestic arrears have been announced publicly.

An action plan has been formulated to implement recommendations of the financial audit of the Ministry of Education.

Diagnostic studies and reforms have been completed in six key ministries to rationalize structure, functions, and staffing in these ministries.

A medium-term budgetary framework incorporating all major mineral revenues has been formulated and discussed with development partners.

Project has been launched to convert the Establishment Secretary's Office into a personnel management office.

Identification cards have been issued for all civil servants.
February 28, 2004

March 15, 2004

May 31, 2004

May 31, 2004

September 30, 2003

September 30, 2003

December 31, 2003

February 28, 2004

Continuous

March 31, 2004

March 31, 2004

March 31, 2004

May 31, 2004

June 30, 2004

June 30, 2004
Observed.

Observed.

Not observed, pending technical assistance from the IMF.

Partially observed. Amendments need to be approved by Cabinet.

Partially observed. Positions have been advertised, and recruitment is under way.

Observed. Software has been received and seven new staff members have been hired.

Not observed. Legislation to be finalized by June 2005 with technical assistance from the Commonwealth Secretariat.

Observed.

Observed.

Not observed.

Observed.

Partially observed.

Not observed.

Not observed. Draft terms of reference for managing the proposed initiative have been prepared.

Not observed.

\footnotetext{
${ }^{1}$ Existing teachers refer to those with valid letters of appointment as of August 31, 2003.

${ }^{2}$ Verified teachers refer to existing teachers as of August 31, 2003 who have been photo verified.
} 
Table 4. Sierra Leone: Structural Performance Criteria and Benchmarks for July - December 2004 Under the Program Supported by the Poverty Reduction and Growth Facility Arrangement

\section{Prior action}

New personnel management regulations for the civil service, establishing a code of ethics, and including a system for performance-based appraisal and promotions, have been introduced.

\section{Performance criteria}

The reconciliation of fiscal and monetary data for 2000-02 has been completed.

November 30, 2004

\section{Benchmarks}

Specific measures have been elaborated to strengthen the Auditor General's Office,

December 31, 2004 including the use of private accounting firms to expedite audits of government ministries and agencies.

At least sixty percent of schools are paid through school bank accounts.

December 31, 2004

The Budgeting and Accountability Act has been presented to Parliament.

October 31, 2004

The ESO database of civil servants and teachers is updated monthly and

Continuous. used to update the payroll database of the Accountant General's Office.

Employment ceilings for individual schools will be published in the government gazette at the beginning of each school year.

Terms and conditions for securitization of all remaining verified domestic arrears have been announced publicly.

September 30, 2004

Diagnostic studies and reforms have been completed in six key ministries to

December 31, 2004 rationalize structure, functions, and staffing in these ministries.

A medium-term budgetary framework incorporating all major mineral revenues has been formulated and discussed with development partners.

August 31, 2004.

Project has been launched to convert the Establishment Secretary's Office into a personnel management office.

December 31, 2004

Identification cards have been issued for all civil servants.

December 31, 2004 


\section{Sierra Leone: Technical Memorandum of Understanding}

\section{October 2004}

\section{INTRODUCTION}

1. This memorandum sets out the understandings between the Sierra Leonean authorities and the International Monetary Fund (IMF) regarding the definitions of the quantitative performance criteria and benchmarks for the program supported by the Poverty Reduction and Growth Facility (PRGF) arrangement, as well as the related reporting requirements. The definitions have been revised to ensure that the memorandum continues to reflect the best understanding of the Sierra Leonean authorities and the Fund staff in monitoring the program. Unless otherwise specified, all quantitative performance criteria and benchmark will be evaluated in terms of cumulative flows from the beginning of the period, as specified in Tables 1 and 3 of the attached Memorandum of Economic and Financial Policies of the Government of Sierra Leone for April 1-December 31, 2004.

\section{Quantitative Performance Criteria: Definitions and Data Sources}

\section{Gross Foreign Exchange Reserves of the Bank of Sierra Leone (BSL)}

2. Definition. Unless otherwise noted here, gross foreign exchange reserves of the Bank of Sierra Leone (BSL) will be defined as reserve assets of the BSL. Reserve assets are defined in the IMF's Balance of Payments Manual $\left(5^{\text {th }} \mathrm{ed}\right.$.) and elaborated in the reserve template of the Fund's International Reserves and Foreign Currency Liquidity: Guidelines for a Data Template. They exclude, for example, foreign assets not readily available to, or controlled by, the monetary authorities.

3. Gross foreign exchange reserves consist of (a) monetary gold; (b) foreign currency in cash; (c) unencumbered foreign currency deposits at non-resident banks; (d) foreign securities and deposits; (e) SDR holdings and Sierra Leone's reserve position with the Fund; and (f) balances in the Bank of England account related to debt service to Paris Club creditors. Gross reserves will exclude nonconvertible currencies and pledged, swapped, or any encumbered reserves assets including but not limited to reserve assets used as collateral or guarantees for third party external liabilities.

4. Adjustment clauses. The floor on gross foreign exchange reserves will be adjusted (a) downward (or upward) by the amount in U.S. dollars of the shortfall/excess in programmed external budgetary assistance ${ }^{40}$; (b) downward (upward) for any shortfall/excess

${ }^{40}$ External budgetary assistance is defined as program grants and program loans, but excluding external financing for the Disarmamanent, Demobilization and Reintegration (DDR) Program, project-related grants and loans. The leone value of the cumulative shortfall 
in the U.S. dollar value of disbursements from the IMF under the PRGF arrangement; and (c) upward or downward for any increase in BSL short-term foreign currency-denominated debt (to residents and nonresidents), using the definition of short-term debt below.

5. For the purpose of this target, as well as of those for external debt and arrears, valuation will be in U.S. dollars, using the program exchange rates. For the 2004 program, the program exchange rates between the U.S. dollar and other non-leone currencies will be those prevailing at March 31, 2004.

6. Supporting material. Data on gross foreign exchange reserves, including its components, will be transmitted by the BSL to the Fund on a weekly basis within ten days of the end of each week.

\section{Net Domestic Assets of the (BSL)}

7. Definition. Net domestic assets (NDA) of the BSL are defined as the end-period (based on daily data) stocks, during the month of the test dates, of the reserve money less net foreign assets calculated at the program exchange rate of 2,735 leones per U.S. dollar. Reserve money includes currency in circulation and required reserves on leone deposits. Net foreign assets of the BSL are defined as gross foreign exchange reserves (defined above) minus foreign liabilities (defined below).

8. Foreign liabilities are defined as short-term (one year or less in original maturity) foreign currency-denominated liabilities of the BSL to nonresidents and the outstanding use of Fund credit.

9. Adjustment clauses. The ceiling on the NDA of the BSL will be adjusted upward by up to fifty percent of the amount of the shortfall in the external budgetary assistance at the test dates. The ceiling will be adjusted downward by the amount of the excess in the external budgetary assistance at the test dates.

10. Supporting material. Net domestic assets of the BSL will be transmitted to the Fund on a monthly basis within four weeks of the end of the month. This report will include foreign assets excluded from the definition of gross foreign exchange reserves in Section IIA above.

(excess) of external budgetary assistance will be calculated at the program exchange rate of 2,735 leones per U.S. dollar. 


\section{Net Domestic Bank Credit to Government (NCG)}

11. Definition. NCG refers to the net banking system's claims on the central government and is defined as the following:

- $\quad$ the net position of the government with commercial banks, including: (a) treasury bills; (b) bonds issued by the Government of the Republic of Sierra Leone (GSL); (c) loans and advances; less (d) Central government deposits (defined to include account balances under the authority of controlling officers); plus

- $\quad$ BSL holdings of (a) GSL statutory bonds; (b) ordinary GSL bonds; (c) bonds in respect of loans to current and former parastatals; (d) treasury bills on the trading portfolio of BSL; (e) other government stock; (f) HIPC debt relief deposits; less (g) special non-interest-bearing government stocks to cover foreign exchange valuation losses.

12. Adjustment clauses. The ceiling on the increase in NCG will be adjusted upward by up to fifty percent of the amount of the shortfall in external budgetary assistance. The ceiling will be adjusted downward by the amount of the excess in external budgetary assistance. The leone value of the cumulative shortfall or excess in external budgetary assistance will be converted at the program exchange rate of 2,735 leone per U.S. dollar. The ceiling will also be adjusted downward (upward) by the net increase (decline) in the leone value of net issues of government securities to the nonbank private sector up to the ceiling set on net domestic bank credit to government for each test date.

13. Supporting material. The data source for the above will be the series "Claims on Government (Net)" submitted to Fund staff on a weekly basis and reconciled with the monthly BSL monetary survey to be submitted to the Fund within six weeks of the end of each month. These data will be reconciled with monthly reports on treasury bill transactions and the ways-and-means account, and with treasury bearer bond transactions to be submitted to the Fund staff by the Ministry of Finance, within six weeks of the end of each month.

\section{Domestic Primary Balance of Central Government}

14. Definition of Central government. Central government is defined for the purposes of this memorandum to comprise the central government and those special accounts that are classified as central government in the BSL statement of accounts. The National Social Security and Insurance Trust (NASSIT) and public enterprises are excluded from this definition of central government.

15. The floor on the domestic primary budget balance of the central government is defined as domestic revenue minus total expenditure and net lending, excluding interest payments, externally financed capital expenditure, and the externally financed DDR program. 
16. Supporting material. The data will be submitted to Fund staff by the Budget Unit of the Ministry of Finance (MFIN) within six weeks of the end of each month.

\section{Domestic Revenue of Central Government}

17. The target on total domestic government revenue is defined as total central government revenue, excluding external grants.

18. Supporting material. The data will be submitted to Fund staff by the Budget Unit of (MFIN) within six weeks of the end of each month.

\section{Central Government Wage Bill}

19. The ceiling on the government wage bill is defined as total expenditure outlays on wages, salaries, pensions, payments to NASSIT and cash allowances by the government.

20. Supporting material. The data will be submitted to Fund staff by the Budget Unit of the Ministry of Finance within six weeks of the end of each month.

\section{Poverty-related Expenditures}

21. Poverty-related expenditures refer to those expenditures in those areas identified in Table 2 of the Sierra Leone HIPC Decision Point Document (www.imf.org). These budgetary expenditures include but are not limited to those sub-components that are financed by drawdown from the HIPC Relief Account at the BSL.

\section{External Payment Arrears}

22. Definition. Official external payment arrears are defined as the stock of external overdue debt-service payments by the public sector. For the purposes of this Memorandum, the public sector will comprise the central government, all public enterprises and the BSL. The nonaccumulation of external arrears is a performance criterion during the program period. Excluded from this performance criterion are those debts subject to rescheduling arrangements. This performance criterion will apply on a continuous basis.

23. Supporting material. Data on arrears are compiled jointly by the MFIN and the BSL and will be reported to Fund staff by the Budget Director of the MFIN on a quarterly basis within six weeks of the end of each quarter. 


\section{Official Medium- and Long-Term Nonconcessional Loans}

24. Definition. Those are defined as all forms of official debt contracted or guaranteed by the public sector. ${ }^{41}$ This performance criterion applies not only to debt as defined in Annex 1of this Technical Memorandum of Understanding but also to commitments contracted or guaranteed for which value has not been received. This performance criterion will apply on a continuous basis. Excluded from this performance criterion are disbursements from the IMF and rescheduling arrangements. In this memorandum, the public sector consists of the central and regional governments and other public agencies, including the BSL.

25. Supporting material. Detailed data on all new concessional and non-concessional debt contracted or guaranteed will be provided to Fund staff by BSL/the Ministry of Finance on a quarterly basis within six weeks of the end of each quarter.

\section{External Short-Term Debt Contracted or Guaranteed by the Public Sector}

26. External short-term debt is defined as external debt with a maturity of less than one year contracted or guaranteed by the public sector. Debt is defined in Annex 1 of this Technical Memorandum of Understanding. For this purpose, short-term debt will exclude normal trade credit for imports. A performance criterion is no new external short-term debt during the program period. This performance criterion will apply on a continuous basis.

27. Supporting material. A comprehensive report on all new external debt with original maturity of less than one year owed or contracted by the public sector will be transmitted to Fund staff by the BSL on a quarterly basis within four weeks of the end of each quarter.

\footnotetext{
${ }^{41}$ Debt is considered concessional if it has a grant element equalent to 35 percent or more. Calculation of the degree of concessionality of new external borrowing is based on the 10year average commercial interest reference rate (CIRR) of the Organization for Economic Cooperation and Development (OECD) for loans with maturities at least 15 years and the six-month average CIRR for loans maturiting in less than 15 years.
} 


\section{Subsidies to the NPA}

28. The term "subsidy" refers to any financial government support (i.e., unrequited transfers) to the National Power Authority (NPA). It does not include the government's onlending of external loans for capital expenditure of the enterprise. The subsidy is to be reduced by the amount of arrears accumulating in regard to the charges for government's electricity consumption. This performance criterion will apply on a continuous basis.

\section{Program-Monitoring Committee}

29. Definition. The Sierra Leonean authorities shall maintain a program-monitoring committee composed of senior officials from the Ministry of Finance, the Ministry of Economic Development and Planning; the Bank of Sierra Leone, and other relevant agencies. The committee shall be responsible for monitoring the performance of the program, recommending policy responses, informing the Fund regularly about the progress of the program, and transmitting the supporting materials necessary for the evaluation of performance criteria and benchmarks. The committee shall provide the Fund with a progress report on the program on a monthly basis within four weeks of the end of each month, using the latest available data.

\section{DATA REPORTING TO THE FUND}

\section{Domestic Prices}

30. Reporting standard. the monthly disaggregated consumer price index will be transmitted within four weeks of the end of each month.

\section{Government Accounts Data}

31. Reporting standard. A consolidated budget report of the central government comprising (a) the revenue data by each major item, including those collected by the National Revenue Authority, as well as privatization receipts to the budget; (b) details of the recurrent and capital expenditure of the central government; (c) details of budget financing (domestic and external), which will be transmitted on a monthly basis within six weeks of the end of each month; and (d) details on the government's outstanding arrears outstanding, including payments and other arrangements to discharge them (these data will be transmitted on a monthly basis within six weeks of the end of each quarter).

\section{Monetary Sector Data}

32. Reporting standard. The balance sheet of the central bank and the consolidated balance sheets of the commercial banks will be transmitted on a monthly basis within six weeks of the end of each month. A special report on transactions in the HIPC relief account at the BSL will be provided to the Fund on a monthly basis within six weeks of the end of each month. The results of the treasury bill auctions will be transmitted on a biweekly basis 
within five business days. The stocks of government securities, balances in the divestiture account, detailed information on interbank loans (terms, duration, and participating institutions), and interest rate developments will be transmitted on a monthly basis within two weeks of the end of each month.

\section{External Sector Data}

33. Reporting standard. The following standard will be adhered to: (a) the interbank market exchange rate, as the simple average of the daily-weighted average buying and selling rates, will be transmitted on a weekly basis within five business days of the end of the week; (b) the results of foreign exchange auctions (on a weekly or more frequent basis) will be transmitted on a weekly basis within five business days of the end of each week; and (c) the foreign exchange cashflow data will be transmitted on a quarterly basis within six weeks of the end of each quarter. 


\section{Implementation of the Revised Guidelines on Performance Criteria with Respect to Foreign Debt}

The term "debt" has the meaning set forth in point No. 9 of the Guidelines on Performance Criteria with Respect to Foreign Debt adopted on August 24, 2000 [which reads as follows: "(a) For the purpose of this guideline, the term "debt" will be understood to mean a current, i.e., not contingent, liability, created under a contractual arrangement through the provision of value in the form of assets (including currency) or services, and which requires the obligor to make one or more payments in the form of assets (including currency) or services, at some future point(s) in time; these payments will discharge the principal and/or interest liabilities incurred under the contract. Debts can take a number of forms, the primary ones being as follows: (i) loans, i.e., advances of money to obligor by the lender made on the basis of an undertaking that the obligor will repay the funds in the future (including deposits, bonds, debentures, commercial loans and buyers' credits) and temporary exchanges of assets that are equivalent to fully collateralized loans under which the obligor is required to repay the funds, and usually pay interest, by repurchasing the collateral from the buyer in the future (such as repurchase agreements and official swap arrangements); (ii) suppliers' credits, i.e., contracts where the supplier permits the obligor to defer payments until some time after the date on which the goods are delivered or services are provided; and (iii) leases, i.e., arrangements under which property is provided which the lessee has the right to use for one or more specified period(s) of time that are usually shorter than the total expected service life of the property, while the lessor retains the title to the property. For the purpose of the guideline, the debt is the present value (at the inception of the lease) of all lease payments expected to be made during the period of the agreement excluding those payments that cover the operation, repair or maintenance of the property. (b) Under the definition of debt set out in point 9(a) above, arrears, penalties, and judicially awarded damages arising from the failure to make payment under a contractual obligation that constitutes debt are debt. Failure to make payment on an obligation that is not considered debt under this definition (e.g., payment on delivery) will not give rise to debt"]. (B) Excluded from this performance criterion are normal import-related credits, disbursements from the IMF, and those debts subject to rescheduling arrangements. 
Sierra Leone: Relations with the Fund

(As of August 31, 2004)

I. Membership Status: Joined 9/10/62; Article VIII.

II. General Resources Account:

Quota

Fund holdings of currency

Reserve position

III. SDR Department:

Net cumulative allocation

Holdings

IV. Outstanding Purchases and Loans:

PRGF Arrangements
SDR Million

103.70

103.69

0.02

SDR Million

17.45

19.31

SDR Million

115.38

$$
\begin{gathered}
\text { \% Quota } \\
100.0 \\
99.99 \\
0.02
\end{gathered}
$$

\% Allocation

100.0

110.61

\begin{tabular}{|c|c|c|c|c|}
\hline Type & $\begin{array}{r}\text { Approval } \\
\text { Date }\end{array}$ & $\begin{array}{r}\text { Expiration } \\
\text { Date }\end{array}$ & $\begin{array}{c}\text { Amount } \\
\text { Approved } \\
\text { (SDR Million) }\end{array}$ & $\begin{array}{c}\text { Amount } \\
\text { Drawn } \\
\text { (SDR Million) }\end{array}$ \\
\hline PRGF & $9 / 26 / 01$ & $3 / 25 / 05$ & 130.84 & 102.84 \\
\hline PRGF & $3 / 28 / 94$ & $5 / 04 / 98$ & 101.90 & 96.85 \\
\hline SAF & $3 / 28 / 94$ & $3 / 27 / 95$ & 27.02 & 27.02 \\
\hline
\end{tabular}

\section{\% Quota}

111.27

V. Latest Financial Arrangements:

VI. Projected Payments to Fund (without HIPC assistance)

(SDR Million; based on existing use of resources and present holdings of SDRs):

Principal

\begin{tabular}{llllr}
\multicolumn{5}{c}{ Forthcoming } \\
\hline$\underline{2004}$ & $\underline{2005}$ & $\underline{2006}$ & $\underline{2007}$ & $\underline{2008}$ \\
\hline 3.33 & 5.66 & $\underline{3.05}$ & 10.81 & 16.37 \\
$\underline{0.29}$ & $\underline{0.55}$ & $\underline{0.53}$ & $\underline{0.49}$ & $\underline{0.43}$ \\
$\underline{3.62}$ & $\underline{6.21}$ & $\underline{3.58}$ & $\underline{11.30}$ & $\underline{16.79}$
\end{tabular}

Total 


\section{Projected Payments to Fund; (with Board-approved HIPC Assistance)}

(SDR Million; based on existing use of resources and present holdings of SDRs):

Principal

Charges/interest

Total
Forthcoming

\begin{tabular}{lllll}
\hline$\underline{2004}$ & $\underline{2005}$ & $\underline{2006}$ & $\underline{2007}$ & $\underline{2008}$ \\
0.20 & 5.66 & 3.05 & 10.81 & 16.37 \\
$\underline{0.29}$ & $\underline{0.55}$ & $\underline{0.53}$ & $\underline{0.49}$ & $\underline{0.43}$ \\
$\underline{0.49}$ & $\underline{6.21}$ & $\underline{3.58}$ & $\underline{11.30}$ & $\underline{16.79}$
\end{tabular}

\section{Implementation of HIPC Initiative:}

$\begin{array}{lr}\text { Commitment of HIPC assistance } & \text { March } 2002 \\ \text { Decision point date } & \text { end-2000 } \\ \text { Assistance committed (NPV terms) } & 42 \\ \text { Total assistance by all creditors (US\$ Million) } & 600.00 \\ \text { Of which: IMF assistance (US\$ Million) } & 123.30 \\ \text { (SDR equivalent in millions) } & 98.48 \\ \text { Completion point date } & \text { Floating } \\ \text { Disbursement of IMF assistance (SDR Million) } & \\ \text { Amount disbursed } & 62.03 \\ \text { Interim assistance } & 62.03 \\ \text { Completion point balance } & 0.0 \\ \text { Total disbursements } & 62.03\end{array}$

\section{Enhanced \\ Framework}

March 2002

d-2000

23.30

98.48

62.03

62.03

62.03

\section{Safeguards Assessment}

Under the Fund's safeguards assessment policy, the Bank of Sierra Leone (BSL) is subject to an assessment with respect to the PRGF arrangement, which was approved on September 26, 2001 and is scheduled to expire on September 24, 2004. A safeguards assessment of the BSL was completed on July 29, 2002. The assessment concluded that substantial risks may exist in the financial reporting framework. Staff findings, proposed recommendations under program conditionality, and other recommendations are reported in "Sierra Leone-Second Review Under the Poverty Reduction and Growth Facility and Request for a Waiver of Performance Criteria," (www.imf.org). Measures are being implemented by the BSL within the prescribed timeframe. Measures with future deadlines continue to be monitored by staff.

${ }^{42}$ Net present value (NPV) terms at the decision point under the enhanced framework. 


\section{Exchange Rate Arrangement}

Since April 25, 1990, the exchange rate has been market determined. Commercial banks may buy and sell foreign exchange from/to individual customers, as well as trade among themselves or with the BSL on a freely negotiable basis. The BSL calculates an official exchange rate every Friday morning as the weighted average of the auction rate, the commercial banks' mid-rate, and the bureaus' mid-rate in the previous week, for customs valuation purposes and for official transactions. As end-August 2004, the BSL mid-rate was Le 2,716.84=US\$1. The exchange rate regime is classified as "independently floating."

With effect from December 14, 1995, Sierra Leone has accepted the obligations of Article VIII, Sections 2, 3, and 4. On June 29, 2001, Sierra Leone removed the remaining exchange restriction, in the form of a tax clearance certificate required for payments and transfers of certain types of current international transactions.

\section{Article IV Consultation}

The 2001 Article IV consultation was concluded by the Executive Board on March 11, 2002. The next Article IV consultation with Sierra Leone will be held in accordance with the provisions of the decision on consultation cycles approved on July 15, 2002.

\section{Technical Assistance}

\begin{tabular}{|l|l|}
\hline Missions & Date \\
\hline MFD mission on improving foreign exchange auction. & January/February 2000 \\
\hline $\begin{array}{l}\text { FAD mission to conduct fiscal sector review and to recommend } \\
\text { reforms in expenditure management and revenue administration. }\end{array}$ & May 2001 \\
\hline $\begin{array}{l}\text { MFD mission on banking supervision and regulation; monetary } \\
\text { operations and framework; and payment systems. }\end{array}$ & May/June 2001 \\
\hline $\begin{array}{l}\text { MFD mission to assess TA needs of the BSL, banking supervision, } \\
\text { and central bank management. }\end{array}$ & November 2001 \\
\hline $\begin{array}{l}\text { FAD mission to review public expenditure management systems. } \\
\text { STA mission to assess the legal-institutional framework for statistics. } \\
\text { MFD mission on banking supervision and regulation and monetary } \\
\text { operations and framework. }\end{array}$ & June 2002 \\
\hline STA GDDS project mission on monetary and financial accounts. & December 2002 \\
\hline
\end{tabular}




\begin{tabular}{|l|l|}
\hline STA GDDS project mission on BOP. & April 2003 \\
\hline $\begin{array}{l}\text { MFD mission on monetary operations, banking supervision, and } \\
\text { payment systems. }\end{array}$ & May/June 2003 \\
\hline STA GDDS follow-up project mission on BOP. & November 2003 \\
\hline $\begin{array}{l}\text { MFD mission to provide and plan follow-up TA to the BSL on } \\
\text { monetary operations, banking supervision, and payment systems. }\end{array}$ & November 2003 \\
\hline $\begin{array}{l}\text { FAD mission to review the tariff and indirect tax system, National } \\
\text { Revenue Authority, and tax and customs administration. }\end{array}$ & February 2004 \\
\hline $\begin{array}{l}\text { STA GDDS project mission on strategic planning. } \\
\text { FAD mission to review the system of fiscal incentives, especially the } \\
\text { special tax regimes applied to mining and petroleum sectors. }\end{array}$ & March/April 2004 \\
\hline STA GDDS project mission on national accounts. & March 2004 \\
\hline $\begin{array}{l}\text { STA GDDS project study tour for Sierra Leonean officials to Kenya } \\
\text { on strategic planning. }\end{array}$ & August 2004 \\
\hline $\begin{array}{l}\text { STA GDDS project mission on national accounts. } \\
\text { reconciliation. }\end{array}$ & September 2004 \\
\hline $\begin{array}{l}\text { STA GDDS project mission on BOP issues. } \\
\text { STA Gotober } 2004\end{array}$ \\
\hline
\end{tabular}

\section{Resident Representative}

A Fund resident representative was stationed in Freetown until May 1997. 


\section{Sierra Leone: Relations with the World Bank Group}

The World Bank, through IDA, has assisted the government in pursuing four main objectives as the country moves out of conflict: (i) consolidating peace, (ii) resettlement, reconstruction, and reintegration, (iii) improving governance, and (iv) maintaining a macroeconomic framework conducive to recovery. Instruments used in supporting these objectives have been the second Public Sector Management Support Project (PSMS II), the Second and Third Economic Rehabilitation and Recovery Credits (ERRC II and III), the Community Reintegration and Rehabilitation Project (CRRP) and the National Social Action Project.

The Bank's Board endorsed a Transitional Support Strategy (TSS) for Sierra Leone for FY 2002-FY 2003 on March 26, 2002. The Bank will complete a successor Country Assistance Strategy (CAS) in FY 2005. The Bank supports the Government's HIV/AIDS Program through the Multi-Sector HIV/AIDS Response Project approved on the same date, under the MAP II.

To meet Sierra Leone's exceptional financing needs in this transitional period, and based on the country's Post-Conflict Performance Rating, in FY03 the Bank provided US\$30 million in adjustment support (ERRC III), US\$20 for the Rehabilitation of Basic Education, US\$20 million for Health Reconstruction and Development, US\$35 million for the National Social Action Project for a total of US\$105 million. In FY 2004 the Bank provided US\$25 million for an Institutional Reform and Capacity Building (ICRB) project. In FY 2005 the Bank has provided US\$35 million for a Power and Water Project and plans a US\$12-15 million quickdisbursing operation in the fourth quarter.

As of September 30, 2003, the World Bank Group has approved 46 loans and credits for a total amount of about US\$721 million, with an undisbursed amount of about US\$157 million. The portfolio consists of eight lending operations, as summarized below, in the areas of adjustment support, poverty reduction, education, health, HIV/AIDS, infrastructure and public sector management totaling US\$215 million. 
Sierra Leone: Financial Relations with the World Bank Group

(As of September 30, 2004; in millions of U.S. dollars)

\begin{tabular}{|c|c|c|c|}
\hline & $\frac{\text { Commi }}{\text { IBRD }}$ & $\begin{array}{l}\text { IDts } \\
\text { IDA } \\
\text { Credit }\end{array}$ & $\begin{array}{l}\text { Of which: } \\
\text { Undisbursed }\end{array}$ \\
\hline \multicolumn{4}{|c|}{ IBRD/IDA Lending Operations } \\
\hline Transportation Sector & 0.00 & 35.0 & 0.34 \\
\hline HIV/AIDS Response Project & 0.00 & 15.0 & 12.34 \\
\hline Health Sector Reconstruction & 0.00 & 20.0a/ & 20.48 \\
\hline Basic Education Rehabilitation & 0.00 & 20.0a/ & 17.69 \\
\hline National Social Action Project & 0.00 & 35.0 & 31.37 \\
\hline ERRC III & 0.00 & 30.0 & 15.39 \\
\hline Institutional Reform and Capacity Building & 0.00 & $25.0 \mathrm{a} /$ & 23.28 \\
\hline Power and Water Project & 0.00 & 35.0 & 35.66 \\
\hline Total & 0.00 & 215.0 & 156.55 \\
\hline Total disbursed (IBRD and IDA) & 18.70 & 702.53 & 721.23 \\
\hline Of which: repaid & 18.16 & 31.59 & 49.75 \\
\hline
\end{tabular}

Source: World Bank Group.

a/ IDA Grant

World Bank Contact: Douglas M. Addison, Senior Economist, Macroeconomics 4, Africa Region, the World Bank (phone: (202) 473-1188). 


\section{Sierra Leone: Statistical Issues}

1. Owing to the prolonged civil war, Sierra Leone's macroeconomic database has serious deficiencies, particularly in the areas of the balance of payments, national accounts, and social indicators. From the May 1997 coup to March 1998, the statistical compilation virtually collapsed because of institutional damage and the departure of key skilled personnel from the administration. Since April 1998, however, the authorities have endeavored to rehabilitate the data collection and compilation systems. The authorities are fully cooperative in providing data to the Fund for purposes of policy formulation and program monitoring. The authorities are also trying to disseminate economic and financial data to the public on a regular basis.

2. A major and sustained improvement in the coverage and timeliness of economic data will require the restructuring of the institutional framework along the lines recommended by the March 2004 IMF/World Bank mission on the development of a strategic plan for the statistical system in Sierra Leone. Budgetary resources remain scarce for the main statistical unit, the Statistics Sierra Leone (SSL); this situation most adversely affects the compilation of national accounts and price statistics. Cooperation and coordination between the main statistical agencies also need to be improved. Sierra Leone is participating in the GDDS regional project for Anglophone African countries that is funded by the Department for International Development (DfID) of the UK. The authorities have prepared an initial set of metadata that include detailed plans for improvement over the short and medium term; these were posted on the Fund's DSBB on May 29, 2003. These metadata were subsequently updated in August 2004. Sierra Leone has received Fund technical assistance in priority areas and additional assistance is expected to be requested in the context of the GDDS project.

\section{National accounts}

3. National accounts data are prepared by the SSL using data received from government ministries and agencies, public enterprises, and through occasional surveys of economic activity. The consumer price index (CPI) is used extensively to derive estimates of GDP at constant prices. A project to improve the system of national income and social accounts was undertaken with Fund/United Nations Development Program (UNDP) technical support. As a result, a set of revised national accounts for the period 1986/87-1994/95 (opening yearclosing month year) was published in December 1995. The main revisions involved the adjustment of trade figures to reflect illegal diamond mining and fishing activity. However, large adjustments were also made to the exports of nonfactor services, for which the SSL was unable to provide sufficient explanation. Data on the exports and imports of services need further improvement and efforts are ongoing to strengthen direct estimation techniques. Fund missions continue to make their own estimates and projections of key national accounts aggregates, as well as adjustments to historical data using available information. The latest available national accounts data refer to 2003. Resource constraints have significantly delayed data production for 2001 and 2002. The SSL should focus on the development of a 
new benchmark for the current price estimates and to rebase the constant price estimates to a new base (current base year is 1990).

4. A national accounts expert visited Freetown in March/April and again in September 2004 under the GDDS project. The expert reviewed the source data, methodologies, and compilation issues. She prepared and agreed with the authorities on a short-term action plan that would bridge the gap to the longer-term improvements that are to be incorporated into the strategic plan.

\section{Prices}

5. The CPI for Freetown is prepared monthly by the SSL and published with a lag of more than three weeks. The CPI covers the capital city only, although with the onset of peace the SSL intends to extend the coverage of the index to towns and selected rural areas. It is desirable for the SSL to compile a national CPI with revised base period weights. A wholesale price index, which has remained dormant for many years, needs to be reestablished.

\section{Government finance statistics}

6. The budget reporting system was established with technical assistance provided under the Fund/UNDP technical assistance project. Monthly data on central government revenue, current expenditure, and financing are being provided, with appropriate disaggregation. The European Commission (EC) is providing technical assistance to the Accountant General's Office that will improve the timeliness and quality of fiscal data. Data on capital expenditure are poor. While Sierra Leone has reported fiscal data to AFR, it has not provided annual data for publication in the GFS Yearbook since 1999. Fiscal data only cover the budgetary central government, excluding extrabudgetary agencies and local governments.

7. There is an urgent need for greater timeliness and accuracy of data on foreignfinanced development projects. Reports on the implementation of the development budget and its financing are currently not produced in a format that is suitable for budget analysis. In particular, data on the implementation is missing. There is also need for assuring quality control of the final data.

\section{Monetary statistics}

8. The main components of the central bank balance sheet are available on a daily and weekly basis; this system provides an early warning system on key financial targets. The full monetary survey is prepared with a lag of about six weeks, with comprehensive coverage of commercial banks.

9. The Bank of Sierra Leone (BSL) is compiling monetary data using a compilation system established by the 1996 STA mission for data reporting to AFR and STA. Most of the mission's recommendations have been implemented, resulting in substantial improvements in the quality of the monetary data. However, commercial banks continue to distinguish 
between their foreign and domestic positions based only on the currency of denomination and not on residency. In addition, the recent GDDS metadata and monetary and financial statistics mission identified that (i) the institutional coverage of monetary statistics does not include those financial corporations that accept nontransferable deposits and (ii) the BSL records the counterpart to the foreign exchange received through foreign grants and loans to the central government as foreign liabilities instead of liabilities to the central government. Some other data problems result from mispostings in the balance sheet of the BSL and misclassifications of new accounts. Also, bank reserves as reported by the BSL and commercial banks, do not match. After considerable work by the authorities and commercial banks the misclassification of government deposits has only been resolved for 2003.

\section{Balance of payments statistics}

10. The BSL is responsible for the compilation of the balance of payments for Sierra Leone. The BSL obtains the data for the balance of payments estimates from various sources including the SSL, government ministries, the Customs and Excise Department (Customs), and the "Financial Survey of Major Limited Companies," for data on foreign direct investment. Goods estimates are based on the import and export data compiled by Customs and are adjusted for coverage, valuation, and timing to fit the balance of payments definitions. However, the BSL does not make adjustments to BOP data using supplementary information to take account of unreported data.

11. Sierra Leone's external transactions are characterized by a large volume of activity in the informal sector, owing principally to the smuggling of diamonds. A considerable portion of imports is financed by these unrecorded exports. As a result, official balance of payments statistics tend to substantially understate transactions. The staff has been addressing this problem through the use of third-country (principally EC member) import data. The Fund's Statistics Department is providing technical assistance under the GDDS project to help the authorities with the implementation of BPM5.

12. Outstanding data problems exist with regard to trade in services, income statistics, current transfers, and in the financial and capital accounts. Regarding the latter, there are, in principle, substantial difficulties in tracking financial transactions of the public and private sectors that are not routed through the central bank but through commercial banks. While the authorities are able to report accurately what public sector debt service payments are after debt relief, they have difficulties in estimating debt service due before debt relief. Estimates of smuggled imports and exports, in particular diamonds, are also not available.

13. Against this background, information on official program grant and loan receipts is relatively good and is prepared by the staff on the basis of contact with the Sierra Leonean authorities and donor agencies. In contrast, data on private capital flows are very poor. Some information on private banking flows can be derived from the monetary survey. Other private capital flows, especially those linked to the informal diamond trade, are effectively captured only in "Errors and omissions." Data on the gross and net official reserves positions of the BSL are provided monthly to the Fund with a short lag. STA has been providing technical 
assistance on BOP issues in the context of the GDDS project and the most recent visit took place in September/October 2004.

14. Information on public external debt is deemed to be good. A comprehensive debtreporting system has been in operation, which is capable of monitoring official external debt and related interest payments. Data on the present stock of private sector external debt are satisfactory, following the verification exercise made in connection with the July 1995 commercial debt buyback operation and the reconciliation exercise undertaken in the context of the HIPC Initiative. 
Sierra Leone: Core Statistical Indicators

(As of September 30, 2004)

\begin{tabular}{|c|c|c|c|c|c|c|c|c|c|c|c|c|}
\hline & $\begin{array}{c}\text { Exchange } \\
\text { Rates }\end{array}$ & $\begin{array}{l}\text { Interna- } \\
\text { tional } \\
\text { Reserves }\end{array}$ & $\begin{array}{c}\text { Central } \\
\text { Bank } \\
\text { Balance } \\
\text { Sheet }\end{array}$ & $\begin{array}{l}\text { Reserve/ } \\
\text { Base } \\
\text { money }\end{array}$ & $\begin{array}{l}\text { Broad } \\
\text { Money }\end{array}$ & $\begin{array}{l}\text { Interest } \\
\text { Rates }\end{array}$ & $\begin{array}{l}\text { Consumer } \\
\text { Price } \\
\text { Index }\end{array}$ & $\begin{array}{l}\text { Exports/ } \\
\text { Imports }\end{array}$ & $\begin{array}{l}\text { Current } \\
\text { Account } \\
\text { Balance }\end{array}$ & $\begin{array}{c}\text { Overall } \\
\text { Govern- } \\
\text { ment } \\
\text { Balance }\end{array}$ & $\begin{array}{l}\text { GDP/ } \\
\text { GNP }\end{array}$ & $\begin{array}{c}\text { External } \\
\text { Debt/ } \\
\text { Debt } \\
\text { Service }\end{array}$ \\
\hline $\begin{array}{l}\text { Date of latest } \\
\text { observation }\end{array}$ & $08 / 04$ & $08 / 04$ & $06 / 04$ & $06 / 04$ & $06 / 04$ & $06 / 04$ & $07 / 04$ & $07 / 04$ & 2003 & $03 / 04$ & 2003 & 2004Q1 \\
\hline Date received & 09/07/04 & 09/07/04 & 07/26/04 & $07 / 26 / 04$ & $07 / 26 / 04$ & $07 / 15 / 04$ & $05 / 19 / 04$ & 07/01/04 & 07/01/04 & $05 / 04$ & 07/01/04 & $07 / 01 / 04$ \\
\hline $\begin{array}{l}\text { Frequency } \\
\text { of data } 1 /\end{array}$ & $\mathrm{D}$ & M 2/ & M 3/ & M 3/ & M 2/ & $\mathrm{W}$ & M & M & A & M & A & $\mathrm{M}$ \\
\hline $\begin{array}{l}\text { Frequency of } \\
\text { reporting } 1 /\end{array}$ & $\mathrm{W}$ & M & M & M & M & M & M & M & $\mathrm{V}$ & M & $\mathrm{V}$ & M \\
\hline Source of update 4/ & A & A & A & A & A & A & A & A & A & $\mathrm{A}$ & $\mathrm{A}$ & A \\
\hline Mode of reporting 5/ & E, T & $\mathrm{E}, \mathrm{C}, \mathrm{T}$ & $\mathrm{E}$ & E, C & $\mathrm{E}, \mathrm{C}$ & E, C & E, C & $\mathrm{E}, \mathrm{C}, \mathrm{V}$ & $\mathrm{E}, \mathrm{C}, \mathrm{V}$ & $\mathrm{E}$ & $\mathrm{E}, \mathrm{C}, \mathrm{V}$ & $\mathrm{E}, \mathrm{C}, \mathrm{M}$ \\
\hline Confidentiality $6 /$ & $\mathrm{C}$ & $\mathrm{C}$ & $\mathrm{C}$ & $\mathrm{C}$ & $\mathrm{C}$ & $\mathrm{C}$ & $\mathrm{C}$ & $\mathrm{C}$ & $\mathrm{C}$ & $\mathrm{C}$ & $\mathrm{C}$ & $\mathrm{C}$ \\
\hline $\begin{array}{l}\text { Frequency of } \\
\text { publication 1/ }\end{array}$ & W & W & M & M & M & W & M & M & A & M & A & M \\
\hline & $\begin{array}{l}\text { D-daily, W- } \\
\text { Weekly estin } \\
\text { Daily estima } \\
\text { A-direct rep } \\
\text { C-cable or fa } \\
\text { C-for unrestr }\end{array}$ & $\begin{array}{l}\text { veekly, M-n } \\
\text { nates provid } \\
\text { tes provided } \\
\text { orting by the } \\
\text { csimile, E-e } \\
\text { icted use. }\end{array}$ & $\begin{array}{l}\text { nonthly, A- } \\
\text { led in Bank } \\
\text { in Bank o } \\
\text { authoritie } \\
\text { lectronic d }\end{array}$ & $\begin{array}{l}\text { annual, V-ir } \\
\text { of Sierra Le } \\
\text { Sierra Leo } \\
\text { ta transfer, }\end{array}$ & $\begin{array}{l}\text { regularly it } \\
\text { one's "Tre } \\
\text { he's "Daily } \\
\text { T-telephon }\end{array}$ & $\begin{array}{l}\text { conjunctio } \\
\text { nds in Mone } \\
\text { Indicators." }\end{array}$ & $\begin{array}{l}\text { n with staff v } \\
\text { tary Variable } \\
V \text {-staff visits. }\end{array}$ & & & & & \\
\hline
\end{tabular}




\section{Sierra Leone: Fiscal Sustainability Analysis}

\section{A. Main results}

This appendix summarizes the results of the fiscal sustainability analysis for Sierra Leone. ${ }^{43}$ The baseline scenario assumes a sustained high output growth together with low inflation. Real output is projected to grow between 6-7 percent annually in the medium term, with inflation reverting to low single digits.

The primary balance is projected to strengthen over the medium-term. This is brought about, on the one hand, by stronger domestic revenue effort and augmentation of the revenue base. An improved revenue effort will be necessary because the share of foreign grants as percent of GDP is projected to decline from 40 percent of total revenues and grants in 2003 to below 10 percent by year 2022. Consequently, current expenditures would need to be covered to large extent by domestic revenues.

On the other hand, government expenditures as a whole are projected to decline to facilitate the attainment of fiscal sustainability in the long run. The reduction should be achieved in part through cost cutting, rationalization, and other reforms to contain costs and improve efficiency of government services. Furthermore, in light of the need to limit expenditures, outlays need to be prioritized reflecting developmental and poverty-related needs (in the context of the PRSP/MDGs, which provide key guidance on this). The share of investment expenditure is also projected to increase to promote high output growth.

The long-run debt-to-GDP and debt-to-revenue ratios are projected to fall in the medium- to long-run (Table 1). As a result of fiscal consolidation and improved fiscal management, staff projects that debt-to-GDP and debt-to-revenue ratios would remain broadly stable or decline in the long run. In part, this is assisted by debt forgiveness under the HIPC Initiative, which will lower the net present value of external public debt. Moreover, lower domestic borrowing (as percent of GDP) helps to alleviate the rising cost of borrowing from domestic sources, a key medium-term risk to fiscal sustainability in Sierra Leone (the share of domestic debt to total debt stock is projected to fall from 41 percent in 2003 to 18 percent in 2022).

\section{B. Sensitivity Analysis}

The overall macroeconomic environment in which the government is operating will have an impact on the fiscal outcome, and by extension fiscal sustainability. That is, changes in real growth and inflation, as well as in the external environment, would need to be offset by fiscal adjustments to preserve long-term fiscal sustainability. Private sector consumption and saving decisions affect interest rates and the cost and level of private investment activity, and eventually economic growth and government's revenue collections and ability to spend on

${ }^{43}$ More details are provided in Chapter 2 of the Selected Issues and Statistical Appendix, 10/29/04 (www.imf.org). 
various public programs. Foreign investments in the country would be equally important for supporting domestic activities and export growth. Expectations and public confidence in the government's ability to implement appropriate economic policies influence private sector decisions and hence need to be fostered. Improved macroeconomic performance and fiscal balance would be essential for medium-term fiscal sustainability. The following conclusion can be made regarding the sensitivity analysis:

- $\quad$ Based on historical averages for real growth and primary fiscal balance, the debt indicators would deteriorate in the long run. Although this reflects the country's volatile past, it also suggests that Sierra Leone needs to maintain a high level of output growth and achieve broadly balanced primary position in the medium-term; otherwise, the fiscal position may not be sustainable. The outcome that further fiscal consolidation will be required is reinforced by the results of a scenario where the fiscal primary balance is kept constant at its level in 2002 leads to an explosive trend.

- A temporary negative output shock could lead to an unsustainable fiscal adjustment and rapidly rising debt-to-GDP and debt service ratios. This is because total expenditures, as a percent of GDP, would rise significantly, leading to a larger primary deficit and borrowing.

- A temporary worsening of the primary balance, which could be caused, for example, by delays in external grant financing, may not necessarily affect the government's long-term fiscal position permanently, provided that the authorities adequately adjust the fiscal portfolio in the medium-term.

Furthermore, a liquidity risk could arise from a higher rollover of short-term domestic debt. In Sierra Leone, virtually all domestic public debt is issued as short-term. ${ }^{44}$ Since there are no long-term debt instruments available in Sierra Leone (beyond the maturity of one year), all future borrowing would be financed through the issuance of short-term debt. In the long-run, this would result in a situation where virtually all domestic debt would be short-term. Given the size of the domestic debt stock at end-2003, equal to about 41 percent of GDP, the debt carries a significant rollover risk. ${ }^{45}$ The government should therefore promote domestic debt markets.

Privatization of state-owned enterprises could also promote fiscal sustainability. The sale of state assets could be used to raise additional revenues to finance poverty-related expenditures or lower the domestic debt stock.

\footnotetext{
${ }^{44}$ The remainder comprises noninterest-bearing debt in the Bank of Sierra Leone balance sheet.

${ }^{45}$ The instrument used to refinance domestic borrowing is 3-month Treasury bills, the debt stock would be rolled over four times in a year.
} 
Table 1. Sierra Leone: Public Sector Debt Sustainability Framework, Baseline Scenario, 2001-2022

(In percent of GDP, unless otherwise indicated)

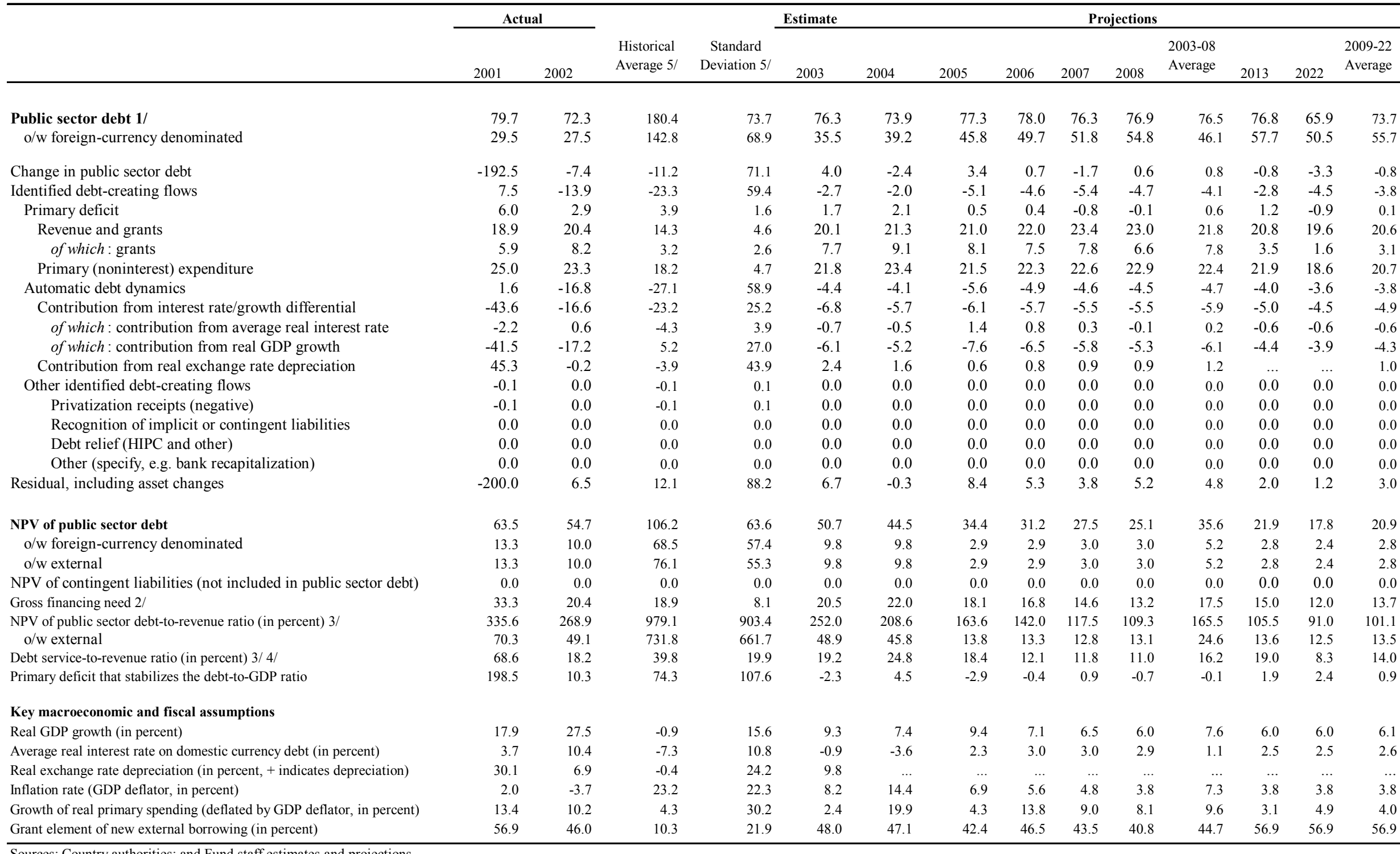

Sources: Country authorities; and Fund staff estimates and projections.

1/ Public sector comprises the central government or nonfinancial public sector. External debt is reported inclusive of unconditional HIPC debt relief.

2/ Gross financing need is defined as the primary deficit plus debt service plus the stock of short-term debt at the end of the last period.

3/ Revenues including grants.

4/ Debt service is defined as the sum of interest and amortization of medium and long-term debt.

5/ Historical averages and standard deviations are generally bsed on data for period 1993-2002. 
Figure 1. Sierra Leone: Indicators of Public Debt Under Alternative Scenarios, 2003-2022 1/
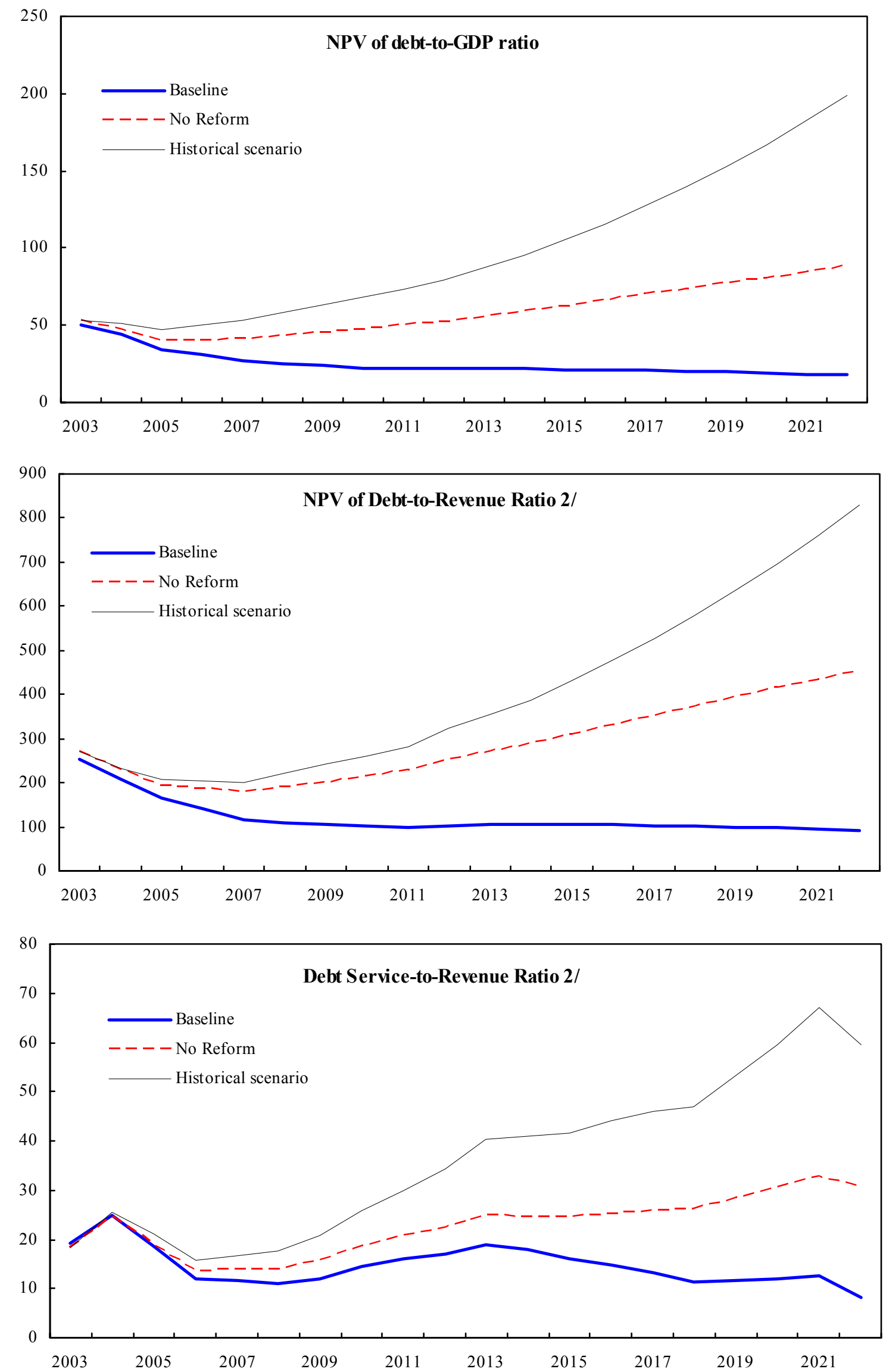

Source: Staff projections and simulations

1/ Historical scenario is based on historic averages for real growth and primary balance over the period 1993-2002 2/ Revenue including grants (excl. domestic debt service) 
Figure 2. Sierra Leone: Indicators of Public Debt Under Alternative Scenarios, 2003-2022 1/
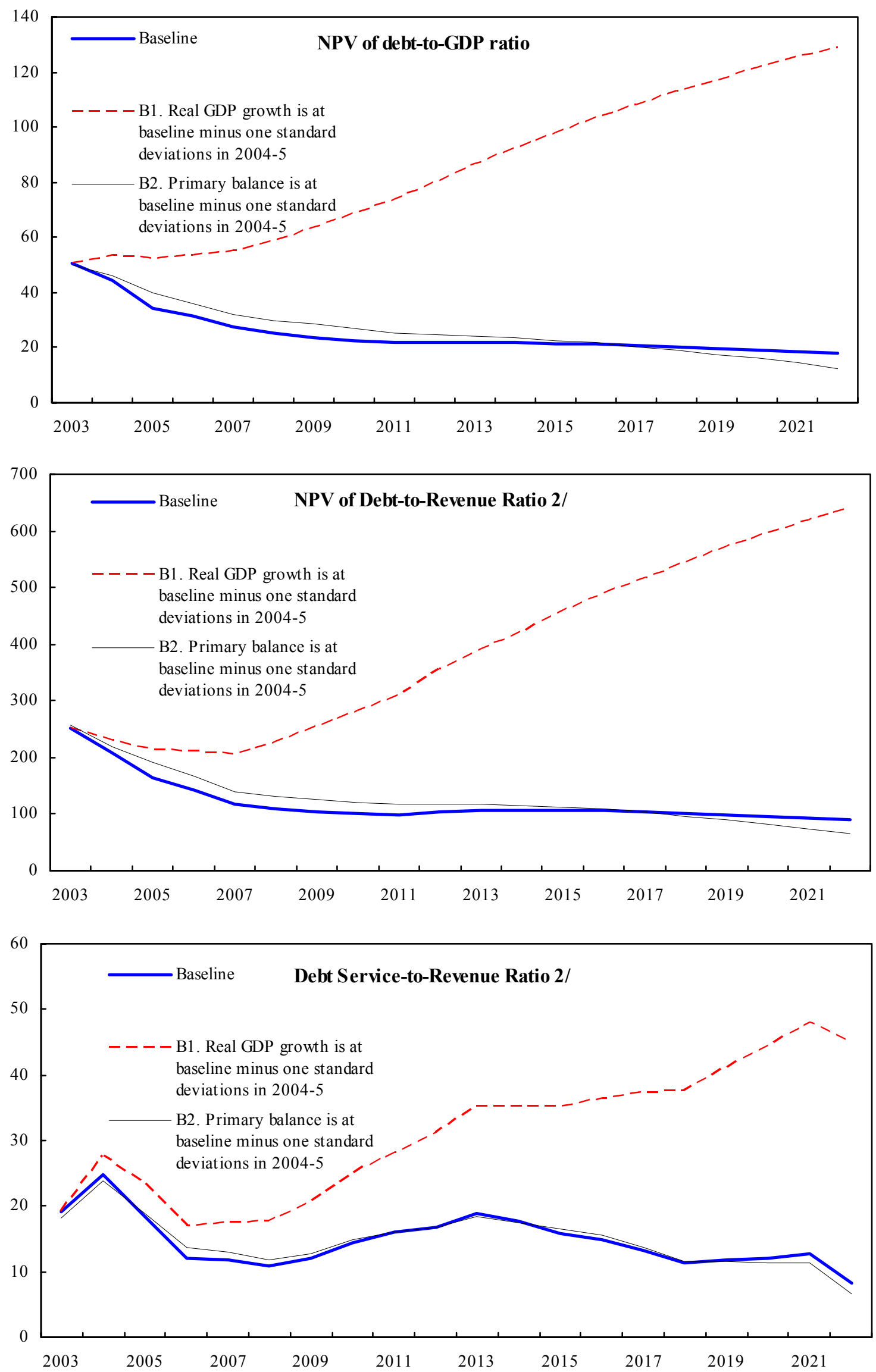

Source: Staff projections and simulations.

1/ Historical scenario is based on averages over the period 1993-2002.

2/ Revenue including grants (excl. domestic debt service). 


\section{Sierra Leone: External Debt Sustainability Analysis}

This section presents the results of updating Sierra Leone's external debt sustainability analysis (DSA). The update of the baseline debt ratios has been done in two steps; first, the decision point DSA has been updated, and then, second, the new DSA framework for lowincome countries has been applied (see Box 1). ${ }^{46}$ The new framework yields estimates for the NPV of debt-to-exports ratio that are somewhat lower than those obtained from calculations using the HIPC methodology. ${ }^{47}$ The baseline scenario under the new framework yields a path for the NPV of debt-to-exports ratio that is fairly stable around 120 percent (Table 1a and Figure 1, middle panel). ${ }^{48}$ The profile for the NPV of debt-to-GDP ratio is somewhat different, with the ratio slowing rising to about 34 percent in 2010 , and then gradually declining to about 25 percent in 2020 (Figure 1, top panel). The debt service ratio stays for most of the projection period below 10 percent (Figure 1, bottom panel). ${ }^{49}$

The NPV of debt-to-exports and -GDP ratios can be considerate moderate, and the debt service ratio is low. For example, the NPV of debt-to-exports and the NPV of debt-to-GDP ratios in non-HIPC low-income countries in 2001 have been 143 and 39 percent respectively, which are both higher than the projected ratios for Sierra Leone after delivery of HIPC relief. ${ }^{50}$ Sierra Leone's debt service ratio of over the medium-term is projected to average about 7 percent, which is only about half the prevailing ratio in non-HIPC low-income countries. ${ }^{51}$ The baseline scenario alone seems to suggest that Sierra Leone is at low risk of debt distress.

The application of stress tests reveals, however, substantial vulnerability to shocks. The stress tests comprise an alternative scenario, where key variables grow in the projection period from 2002 onwards at their historic rates, and shocks to individual variables. ${ }^{52}$ The

${ }^{46}$ All debt ratios assume full and unconditional delivery of HIPC relief, and additional bilateral relief beyond HIPC, beginning in 2000.

${ }^{47}$ As discussed in Box 1, this is mainly because of different discount rate assumptions, and because the new framework uses current exports instead of the backward-looking three year average used under HIPC.

${ }^{48}$ Under the HIPC methodology, the NPV of debt-to-exports ratio stays around 145 percent.

${ }^{49}$ The increase in the debt service ratio in the period 2010-15 is due to projected large amortization payments falling due to the Fund in this period, and a slowdown in export growth as kimberlite and rutile mines reach the end of their production life.

${ }^{50}$ See Initiative for Heavily Indebted Poor Countries - Status of Implementation, Table 1.

51 Ibid.

52 The projection period begins in 2002, because only the loan-by-loan update of the DSA that will be conducted at the completion point will determine the final debt numbers for the period after the decision point. 
historic growth rates and standard deviations, which are used to calibrate the shocks, are computed on the basis of data for the period 1992-2000. The historic scenario shows nonstabilizing debt dynamics for the two debt stock indicators, and high debt service ratios (solid thin line in Figure 1). The other stress tests (broken line) show large vulnerabilities to onestandard deviation GDP and export growth shocks, and to a less severe but simultaneous shock to all variables (combined negative shock). These shocks raise the debt ratios to clearly unsustainable levels, yet one-standard deviation shocks occur relatively frequent so that they cannot be considered 'extreme'.

A possible explanation for the large vulnerability to shocks is that during the entire period 1992-2000, which was used to calibrate the shocks, Sierra Leone was engulfed in civil war. In this sense, the stress tests could reveal nothing more than that should the country slide back into war, its current debt will become once again unsustainable. To test this, a second alternative scenario has been computed, where all shocks have been calibrated based on historic data for the 1980s. The results, however, confirm those from the first set of stress tests: debt dynamics become unsustainable even if key variables grow at their historic rates from the 1980s (Table 1b). In sum, the vulnerability to shocks makes it necessary to consider Sierra Leone not at low, but at moderate risk of debt distress, even after the full delivery of HIPC relief. Maintaining low debt ratios is necessary to protect against the consequences of negative shocks, which have occurred frequently in the past. To achieve this, it will be necessary to continue to borrow on highly concessional terms and to seek grants whenever possible. 


\section{Box 1: Update of Sierra Leone's Debt Sustainability Analysis (DSA)}

The update of Sierra Leone's debt sustainability analysis was done in two steps:

1. Sierra Leone's decision point DSA was updated to reflect end-2003 discount and exchange rates, and new borrowing and export assumptions:

a. The decline in the average discount rate by about 170 basis points and the depreciation in the US dollar by about 15 percent against major currencies since end-2000 (i.e., the base year for the decision point DSA) led to an increase in the NPV of debt by about 30 percent.

b. New borrowing in the period 2001-04 is somewhat lower than expected, but medium-term borrowing projections have been revised upwards significantly. The decision point DSA had assumed a sharp decline in average annual new borrowing from about US\$110 million in 2001-04 to US\$45 million in the medium-term, whereas the updated DSA assumes that new borrowing over the medium term will approximately remain at 2001-04 levels of about US\$90 million per annum, partly because absorptive capacity has increased recently (new borrowing is likely to reach US\$130 million in 2004).

c. Export performance in 2001-04 was largely as expected, but medium term projections have been revised upwards, reflecting, inter alia, the beginning of large-scale diamond mining (Koidu kimberlite mine). This partly offsets the upward revision in new borrowing.

In sum, the updated NPV of debt-to-exports ratio is somewhat higher than projected at the decision point, with the NPV of debt-to-exports ratio leveling off now at about 135 percent (Figure 1).

Figure 1: Comparison of updated projections with decision point projections

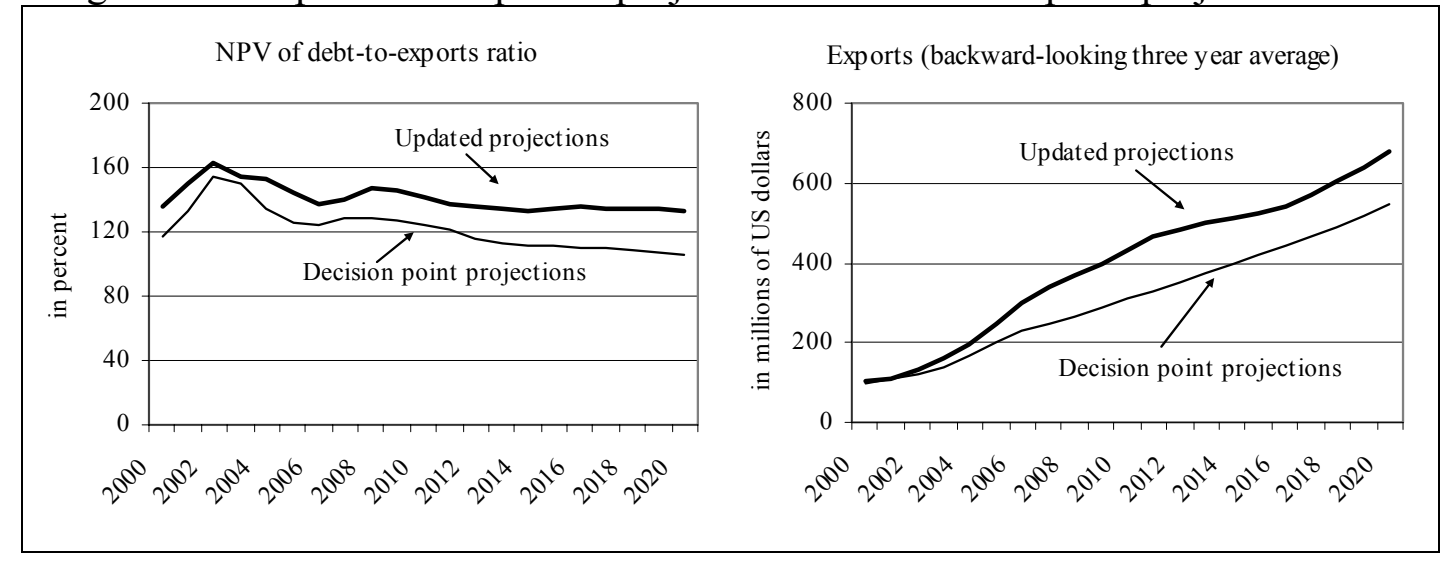




\section{Box 1: continued}

2. In a second step, the methodology of the new DSA framework for low-income countries has been applied. Debt service and export projections are used as inputs into a template that computes baseline projections for the NPV of debt-to-exports ratio and then subjects the baseline to various stress tests. These baseline projections for the NPV of debt-to-export ratio differ from those computed in the first step under the HIPC methodology in two ways (Figure 2):

a. The template uses a discount rate of 5 percent, which is about 60 basis points higher than the currency-specific discount rates used under HIPC. This lowers the NPV of debt by about five percent relative to the HIPC methodology. (Figure 2, broken line)

b. The NPV of debt-to-exports ratio is computed relative to current exports, as opposed to the backward-looking three year average used under the HIPC methodology. In years when exports are growing rapidly, for example in 2000-06, the current-exports series is higher by 20 percent than the series for the backward-looking average. In contrast, in years when export growth is flat, i.e. in the period 2013-15 when the Koidu kimberlite mine reaches the end of its production life, the difference is small. (Figure 2, solid thin line)

Figure 2: NPV of debt-to-exports ratio under new DSA and HIPC methodologies

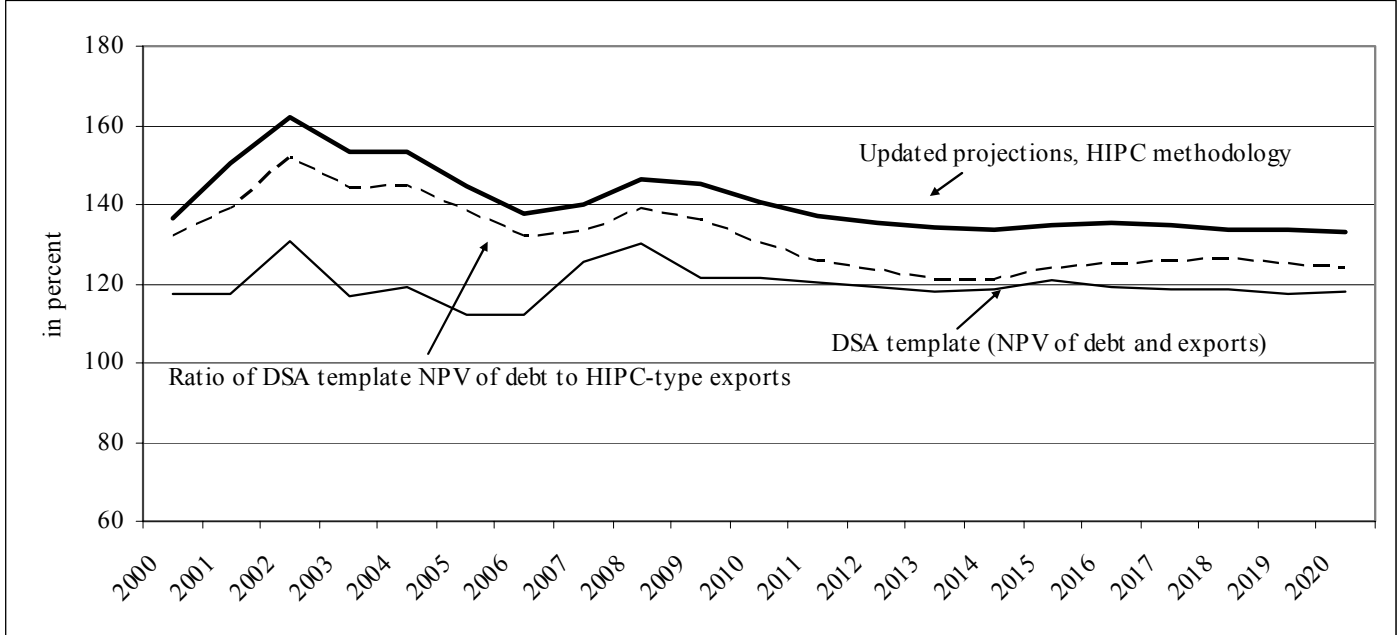


Table 1a. Country: External Debt Sustainability Framework, Baseline Scenario, 2000-2023 1/

(In percent of GDP, unless otherwise indicated)

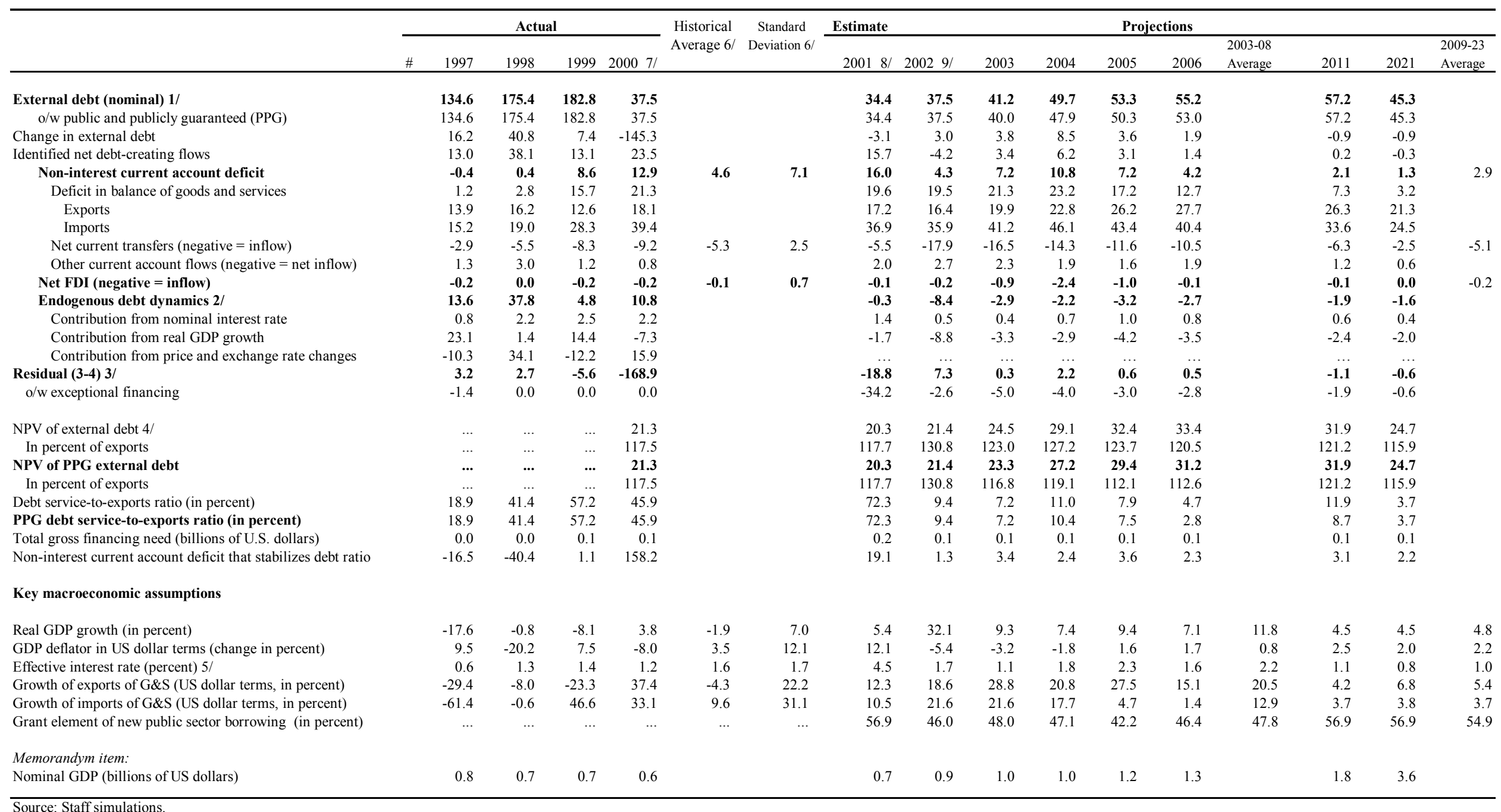

Source: Staff simulations.

1/ Includes both public and private sector external debt. From 2000 onwards unconditional delivery of HIPC relief is assumed.

2/ Derived as $[\mathrm{r}-\mathrm{g}-\rho(1+\mathrm{g})] /(1+\mathrm{g}+\rho+\mathrm{g} \rho)$ times previous period debt ratio, with $\mathrm{r}=$ nominal interest rate; $\mathrm{g}=$ real GDP growth rate, and $\rho=$ growth rate of GDP deflator in U.S. dollar terms.

3/ Includes exceptional financing (i.e., changes in arrears and debt relief); changes in gross foreign assets; and valuation adjustments. For projections also includes contribution from price and exchange rate changes

4/ Assumes that NPV of private sector debt is equivalent to its face value. For public and public guaranteed debt, unconditional delivery of HIPC relief from 2000 onwards is assumed.

5/ Current-year interest payments devided by previous period debt stock.

6/ Historical averages and standard deviations are generally derived over the past 10 years, subject to data availability.

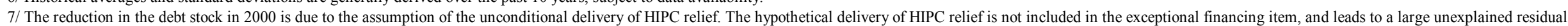

8/ The large exceptional financing item in 2001 reflects a Paris Club rescheduling on Naples terms. The large debt service ratio is due to the repayment of post-emergency assistance to the Fund.

9/ In 2002, the BOP was compiled for the first time on the basis of the Balance of Payments Manual Fifth Edition, which led to a large upward revision in private transfers. Another major change ocurred in the compilation of

national accounts data, where the use of new survey instruments has led to better measurement of previously unrecorded activity, which resulted in a large upward revision in GDP. 


$\begin{array}{llllllll}2001 & 2002 & 2003 & 2004 & 2005 & 2006 & \mathbf{2 0 1 1} & 2021\end{array}$

\section{NPV of debt-to-GDP ratio}

Baseline

\section{A. Alternative Scenarios}

A1. Key variables at their historical averages of the 1990s in 2002-21 1/ A2. Key variables at their historical averages of the 1980s in 2002-21 1/ A3. New public sector loans on less favorable terms in 2002-21 2/
20

$20 \quad 26$

$20 \quad 26$

20

20

2002

(2003

20

2004

2

200

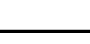

.

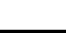

2011

\section{B. Bound Tests}

B1. Real GDP growth at historical average minus one standard deviation in 2002-03

B2. Export value growth at historical average minus one standard deviation in 2002-03 3/

B3. US dollar GDP deflator at historical average minus one standard deviation in 2002-03

B4. Net non-debt creating flows at historical average minus one standard deviation in 2002-03 4/

B5. Combination of B1-B4 using one-half standard deviation shocks

B6. One-time 30 percent nominal depreciation relative to the baseline in 2002 5/

\section{NPV of debt-to-exports ratio}

Baseline

\section{A. Alternative Scenarios}

A1. Key variables at their historical averages of the 1990s in 2002-21 1/

A2. Key variables at their historical averages of the 1980s in 2002-21 1/

A3. New public sector loans on less favorable terms in 2002-21 2/

\section{B. Bound Tests}

B1. Real GDP growth at historical average minus one standard deviation in 2002-03

B3. US dollar GDP deflator at historical average minus one standard deviation in 2002-03

B4. Net non-debt creating flows at historical average minus one standard deviation in 2002-03 4/

B5. Combination of B1-B4 using one-half standard deviation shocks

B6. One-time 30 percent nominal depreciation relative to the baseline in 2002 5/
B2. Export value growth at historical average minus one standard deviation in 2002-03 3/

$\begin{array}{llllllll}118 & 131 & 117 & 119 & 112 & 113 & \mathbf{1 2 1} & 116 \\ & & & & & & & \\ 118 & 156 & 138 & 133 & 132 & 141 & \mathbf{1 9 7} & 321 \\ 118 & 157 & 140 & 136 & 135 & 146 & \mathbf{2 1 3} & 358 \\ 118 & 144 & 134 & 145 & 140 & 142 & \mathbf{1 7 3} & 171\end{array}$

$\begin{array}{llllllll}118 & 131 & 117 & 119 & 112 & 113 & \mathbf{1 2 1} & 116 \\ 118 & 240 & 455 & 445 & 405 & 398 & \mathbf{4 1 3} & 363 \\ 118 & 131 & 117 & 119 & 112 & 113 & \mathbf{1 2 1} & 116 \\ 118 & 176 & 188 & 181 & 162 & 158 & \mathbf{1 6 1} & 135 \\ 118 & 261 & 466 & 441 & 392 & 379 & \mathbf{3 7 9} & 307 \\ 118 & 131 & 117 & 119 & 112 & 113 & \mathbf{1 2 1} & 116\end{array}$

Debt service ratio

Baseline 7/

\section{A. Alternative Scenarios}

A1. Key variables at their historical averages of the 1990s in 2002-21 1/

A2. Key variables at their historical averages of the 1980s in 2002-21 1/

A3. New public sector loans on less favorable terms in 2002-21 2/

11

9

7

10

8

4

$11 \quad 12$

$11 \quad 12$

11

10

10

$\begin{array}{llll}15 & 10 & 4 & \mathbf{2 0}\end{array}$

$\begin{array}{rrrr}15 & 11 & 4 & \mathbf{2 3} \\ 12 & 9 & 5 & 7\end{array}$

14

17

12

\section{B. Bound Tests}

B1. Real GDP growth at historical average minus one standard deviation in 2002-03

B2. Export value growth at historical average minus one standard deviation in 2002-03 3/

B3. US dollar GDP deflator at historical average minus one standard deviation in 2002-03

B4. Net non-debt creating flows at historical average minus one standard deviation in 2002-03 4/

B5. Combination of B1-B4 using one-half standard deviation shocks

B6. One-time 30 percent nominal depreciation relative to the baseline in 2002 5/

$\begin{array}{rrr}11 & 10 & 8 \\ 11 & 16 & 23 \\ 11 & 10 & 8 \\ 11 & 10 & 8 \\ 11 & 14 & 18 \\ 11 & 10 & 8\end{array}$

11
33
11
12
26
11

7
22
7
8
18
7

105

$31 \quad 19$

10

12

26

10

Memorandum item:

Grant element assumed on residual financing (i.e., financing required above baseline) 6/

54

54

\footnotetext{
Source: Staff projections and simulations.
}

1/ Variables include real GDP growth, growth of GDP deflator (in U.S. dollar terms), non-interest current account in percent of GDP, and non-debt creating flows.

$2 /$ Assumes that the interest rate on new borrowing is by 2 percentage points higher than in the baseline., while grace and maturity periods are the same as in the baseline.

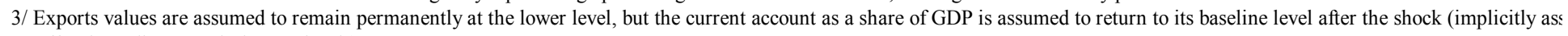
an offsetting adjustment in import levels).

4/ Includes official and private transfers and FDI.

$5 /$ Depreciation is defined as percentage decline in dollar/local currency rate, such that it never exceeds 100 percent.

6/ Applies to all stress scenarios except for A2 (less favorable financing) in which the terms on all new financing are as specified in footnote 2.

7/ For comparability, the debt service ratio for 2001 excludes the effect of the repayment of post-emergency assistance to the Fund. 
Figure 1. Indicators of Public and Publicly Guaranteed External Debt Under Alternative Scenarios, 2001-21
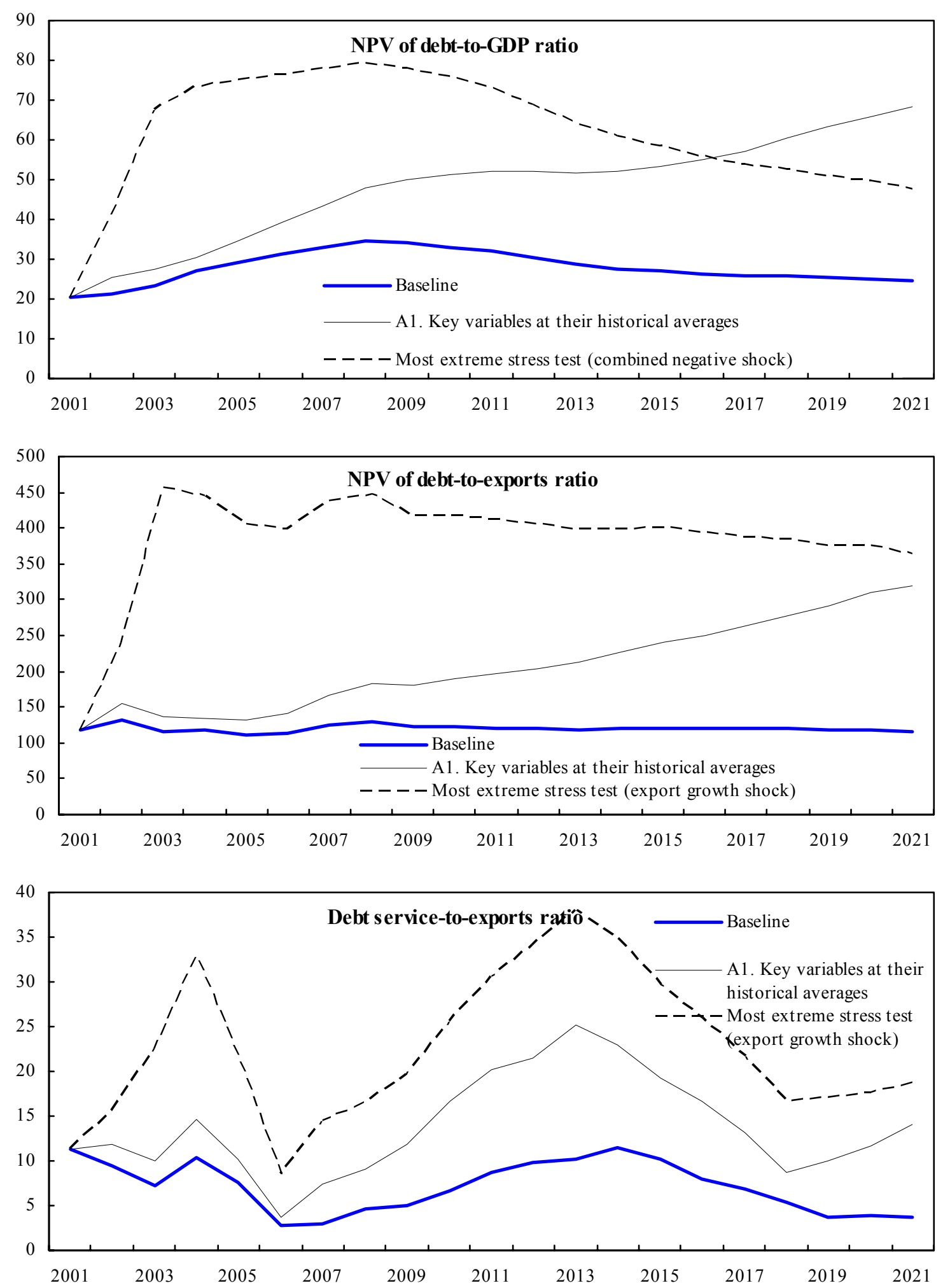

Source: Staff Projections and simulations. 


\section{Statement by the IMF Staff Representative November 12, 2004}

1. This statement provides further information by the staff on the progress made by the authorities in preparing a full poverty reduction strategy paper (PRSP). ${ }^{1}$ The information is based on the authorities' PRSP Preparation Status Report. The contents of this statement does not alter the thrust of the staff appraisal. Fund staff's assessment is shared by the staff of the World Bank.

2. The authorities' preparation status report outlines the various stages and processes leading to the production of the draft PRSP. Against the backdrop of the serious capacity constraints and the country's postconflict circumstances, Fund staff considers that Sierra Leone is making adequate progress in the preparation of its PRSP. In the interim, weaknesses in Sierra Leone's poverty reduction strategy that are critical to Fund support under the PRGF arrangement are also being addressed.

3. Beyond this, the staff has advised that policy actions on various sectors need clearer prioritization and sequencing to facilitate implementation. Donors have also noted that food security and good governance, key priorities for Sierra Leone, should be adequately emphasized in poverty reduction efforts. Future allocation of expenditures should also be consistent with the strategic priorities and the medium-term budget. Furthermore, the staff has suggested that the implementation of the PRSP should be placed within existing central and local government structures. The authorities have indicated that the existing Development Assistance Coordination Office (DACO) would be given responsibility for the overall coordination of PRSP implementation. The staff has also advised that data development issues should be integrated more clearly into the PRSP process, to facilitate monitoring and donor assistance. The General Data Dissemination Standards (GDDS) framework, which Sierra Leone subscribes to, provides a basis for identifying key areas and the related technical assistance and other costs.

\footnotetext{
${ }^{1}$ Paragraph 57 of the staff report contains a discussion on the PRSP process.
} 


\section{INTERNATIONAL MONETARY FUND}

Public Information Notice

EXTERNAL

RELATIONS

DEPARTMENT

Public Information Notice (PIN) No. 05/5

FOR IMMEDIATE RELEASE

January 19, 2005
International Monetary Fund

$70019^{\text {th }}$ Street, NW

Washington, D. C. 20431 USA

\section{IMF Concludes 2004 Article IV Consultation with Sierra Leone}

On November 12, 2004. the Executive Board of the International Monetary Fund (IMF) concluded the Article IV consultation with Sierra Leone. ${ }^{1}$

\section{Background}

The authorities have been implementing wide-ranging structural reforms and pursuing prudent macroeconomic policies, supported by the PRGF arrangement since 2001. With enhanced economic and political stability, real GDP growth has picked up while inflation has remained moderate. During 2003, the economy enjoyed a robust recovery, reflecting robust activity in agriculture, mining, manufacturing, and services, but inflation accelerated. Average inflation in June 2004 reached 12 percent.

Further progress was made in 2003 towards completing Sierra Leone's post-conflict transition. The government concluded the disarmament, demobilization, and reintegration (DDR) exercise in February 2004. Security in neighboring Liberia has improved and will enhance stability in Sierra Leone.

Growth prospects in the medium term are encouraging, largely based on some mining projects coming to fruition, agricultural expansion, and service-related activities. Real growth is projected in the range of 6-7 percent in 2005-07 (with higher growth in 2005 led by mineral exports), reflecting these activities in the country's post-conflict phase. Inflation is expected to revert to low single digits, while the current account deficits would narrow, aided by growth in

\footnotetext{
${ }^{1}$ Under Article IV of the IMF's Articles of Agreement, the IMF holds bilateral discussions with members, usually every year. A staff team visits the country, collects economic and financial information, and discusses with officials the country's economic developments and policies. On return to headquarters, the staff prepares a report, which forms the basis for discussion by the Executive Board. At the conclusion of the discussion, the Managing Director, as Chairman of the Board, summarizes the views of Executive Directors, and this summary is transmitted to the country's authorities.
} 
mineral exports. The projected strong growth will, however, still leave Sierra Leone quite far in terms of achieving the MDGs.

The authorities' overall medium-term strategy for promoting growth and reducing poverty focuses on six key strategic areas: continued strengthening of state security; aiming at a more sustainable fiscal position; raising domestic savings and investment; strengthening infrastructure; agricultural and rural development; and the promotion of the private sector.

Fiscal performance in 2003 was somewhat weaker than envisioned, largely due to domestic expenditure overruns. External program financing (5.5 percent of GDP in the original program) only materialized at slightly over 3 percent of GDP. This led to much larger than programmed domestic financing of the budget, especially from the banking system. Poverty-related outlays were above the programmed level. Fiscal pressures continued in the first quarter of 2004. While the government made an effort to scale down its outlays, this was insufficient to offset the large shortfall in external non-HIPC grants and program loans. Therefore, domestic financing of the budget exceeded the program target by a large margin.

Monetary policy in 2003 was expansionary, as Bank of Sierra Leone allowed private sector credit to continue growing at a rapid pace. Monetary policy also accommodated the expansionary fiscal policy. Treasury bill interest rates began to rise in late 2003 in response to inflation expectations and large government borrowing. As a result, broad and reserve money growth rates were higher than programmed for the year as a whole. A rapid monetary growth has continued in 2004.

The external current account weakened further in 2003. While export performance during the year improved, particularly for diamonds, imports remained high due to continued expansion in reconstruction activities and the high cost of fuel. Gross official reserves fell to 1.5 months of imports, which was well below the program level. The real effective exchange rate depreciated by 17 percent in 2003, partly reflecting the high foreign-exchange demand of the private sector as a result of higher oil prices.

Debt relief agreements with most official creditors have been reached, but there has been little progress with commercial creditors. Debt relief agreements on Naples terms have been signed with Paris Club creditors except Japan, and seven out of eleven agreements on Cologne terms have been signed. Significant reduction in the NPV of debt to exports is expected after Sierra Leone reaches the Heavily Indebted Poor Countries (HIPC) completion point. All non-Paris Club official creditors have agreed to deliver debt relief, or indicated their willingness to do so, even though the terms in some cases fall short of what is expected under the HIPC Initiative. The authorities have also requested the World Bank for a debt buyback operation under the International Development Association facility in order to continue addressing the problem of commercial debt arrears.

The authorities have completed the first draft of the full Poverty Reduction Strategy Paper (PRSP) and have indicated that a final version of the PRSP would be ready by end-2004. The exercise to prepare the document had been undertaken in broad consultation with various sections of society. 


\section{Executive Board Assessment}

Executive Directors commended the authorities on concluding the disarmament, demobilization, and reintegration (DDR) exercise for over 72,000 former combatants in February 2004, which led to a significant improvement in the security situation of the country. Directors welcomed the United Nations' decision to maintain a presence in the country at least until mid-2005, thus providing additional time for the Sierra Leonean government to train and equip its police and military forces.

Directors noted that Sierra Leone's economic recovery had been broad-based, reflecting improved business confidence. Significant output gains had been made from post-conflict low levels, especially in agriculture, mining, manufacturing, and services. Real output in 2003 is estimated to have increased by 9.3 percent. However, Directors expressed concern that inflation had accelerated resulting initially from higher fuel costs, but later also reflecting expansionary monetary policy and a depreciating currency.

Directors supported the authorities' overall medium-term strategy for sustaining high growth and reducing poverty. The strategy focuses on the strengthening of state security; the attainment of a more sustainable fiscal position; raising savings and investment; strengthening of infrastructure; agricultural and rural development; and the promotion of the private sector. Directors also endorsed the authorities intention to maintain a floating exchange rate system, given the open economy and the need to maintain a competitive external position.

Directors encouraged the authorities to continue addressing structural reforms and governance issues with the aim of attracting both domestic and foreign investors. In this context, Directors welcomed the finalization and imminent adoption of the new investment code. They also commended the authorities on expressing interest in participating in the Extractive Industries Transparency Initiative (EITI), which would address governance concerns and enhance the transparency of reporting on mineral revenues. Looking forward, Directors pointed out that the main risk to the medium term growth strategy lies in the area of saving and investment; therefore, the policy and institutional measures required in this broad area would remain critical.

Directors broadly endorsed the macroeconomic objectives and policies for the remainder of 2004. They concurred with the need to tighten fiscal policy to bring domestic expenditures, excluding as much as possible poverty related expenditures, closer to projected resources. In order to reduce inflationary pressures, Directors also emphasized the need to maintain an appropriately tight monetary policy, including the authorities' planned reduction in government borrowing from the banking system in the second half of the year.

In light of the proposed policy framework for the remainder of 2004, Directors granted waivers for (i) the ceiling on net bank credit to the government, which was exceeded after adjusting for the shortfall in the external program support, (ii) the introduction of new personnel management regulations, which was not introduced by end-May 2004 as envisaged, pending the finalization of a new employment scheme for senior civil servants, and (iii) reconciliation of fiscal and monetary data for 2000-02, which was not completed by the end-May 2004 deadline, as the provision of Fund technical assistance was not forthcoming as projected. In addition, Directors agreed to extend the arrangement for a three-month period. 
Directors commended the authorities on the completion of a comprehensive first draft of the full PRSP, which was produced by a relatively broad based national participatory process.

Given the requirement to implement the full PRSP at least a year before reaching the HIPC completion point, which is envisaged for end-2005, Directors urged the authorities to complete the PRSP document by end-December 2004. Directors also recommended that the full PRSP serve as an active vehicle for pursuing medium-term objectives as well as the longer term MDGs.

Directors commended the authorities for the progress made in implementing the recommendations of previous statistics technical assistance missions. To further enhance the surveillance of the economy, they urged the authorities to continue their efforts to improve the statistical base, especially the national accounts, through Fund and other technical assistance.

Public Information Notices (PINs) form part of the IMF's efforts to promote transparency of the IMF's views and analysis of economic developments and policies. With the consent of the country (or countries) concerned, PINs are issued after Executive Board discussions of Article IV consultations with member countries, of its surveillance of developments at the regional level, of post-program monitoring, and of ex post assessments of member countries with longer-term program engagements. PINs are also issued after Executive Board discussions of general policy matters, unless otherwise decided by the Executive Board in a particular case. 
Table 1. Sierra Leone: Selected Economic and Financial Indicators, 2001-04

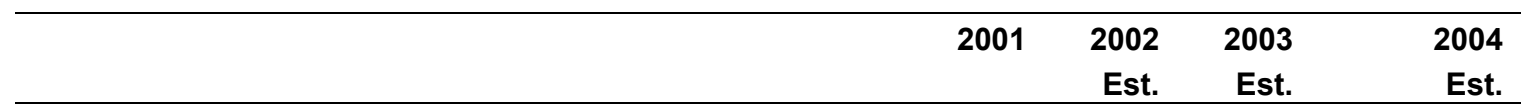

(Annual percentage change, unless otherwise indicated)

\begin{tabular}{|c|c|c|c|c|}
\hline \multicolumn{5}{|l|}{ National Income and Prices } \\
\hline Real GDP & 17.9 & 27.5 & 9.3 & 7.4 \\
\hline Nominal GDP & 20.3 & 22.8 & 18.3 & 22.8 \\
\hline Consumer prices (end of period) & 3.4 & -3.1 & 11.3 & 12.8 \\
\hline Consumer prices (annual average) & 2.6 & -3.7 & 8.2 & 13.6 \\
\hline \multicolumn{5}{|l|}{ Money and credit } \\
\hline Broad money (including foreign currency deposits) & 33.7 & 30.1 & 23.9 & 15.6 \\
\hline Velocity (GDP/broad money) & 5.5 & 5.2 & 5.0 & 5.3 \\
\hline Domestic credit $1 /$ & 22.5 & 7.9 & 40.6 & 6.3 \\
\hline Government 1/ & 19.4 & 0.2 & 19.5 & -2.0 \\
\hline Private sector $1 /$ & 3.2 & 7.5 & 20.1 & 8.4 \\
\hline Reserve money & 29.4 & 24.9 & 22.4 & 6.4 \\
\hline Treasury bill rate $2 /$ & 14.7 & 15.0 & 20.2 & 27.0 \\
\hline \multicolumn{5}{|l|}{ External sector } \\
\hline Exports (U.S. dollars) & 6.1 & 48.9 & 27.4 & 26.2 \\
\hline Imports (U.S. dollars) & 20.6 & 54.4 & 15.6 & 22.7 \\
\hline Terms of trade (- deterioration) & 1.7 & 0.0 & -0.1 & -2.0 \\
\hline Real effective exchange rate (- depreciation; end of period) & -15.3 & -9.7 & -17.2 & $\ldots$ \\
\hline Exchange rate (leones per U.S. dollar, average) & 1986.2 & $\begin{array}{r}2099.0 \\
\text { (In per }\end{array}$ & $\begin{array}{l}2347.9 \\
\text { ent of GD }\end{array}$ & 2735.0 \\
\hline Gross domestic investment & 7.6 & 10.1 & 14.3 & 21.4 \\
\hline Government & 4.8 & 4.4 & 4.9 & 8.9 \\
\hline Private & 2.8 & 5.7 & 9.4 & 12.5 \\
\hline Gross national saving & -9.9 & 5.3 & 6.7 & 9.9 \\
\hline Gross domestic saving & -10.0 & -9.4 & -7.1 & -1.8 \\
\hline Government & -3.2 & -4.3 & -3.3 & -1.2 \\
\hline Private & -6.8 & -5.1 & -3.8 & -0.6 \\
\hline Current account balance, including official transfers & -17.4 & -4.8 & -7.6 & -11.5 \\
\hline Overall balance of payments & 1.7 & -0.3 & -4.6 & -2.6 \\
\hline Net present value of debt-to-exports ratio $3 /$ & 150.6 & 162.3 & 153.6 & 153.3 \\
\hline \multicolumn{5}{|l|}{ Government budget } \\
\hline Domestic revenue & 13.0 & 12.1 & 12.4 & 12.2 \\
\hline Total expenditure and net lending & 29.5 & 28.6 & 26.9 & 28.8 \\
\hline \multicolumn{5}{|l|}{ Overall fiscal balance (commitment basis, including grants) } \\
\hline Domestic primary fiscal balance 4/ & -7.7 & -7.0 & -5.6 & -2.9 \\
\hline Domestic financing & 3.2 & 0.9 & 4.3 & 1.5 \\
\hline
\end{tabular}


Table 1. Sierra Leone: Selected Economic and Financial Indicators, 2001-04

\begin{tabular}{|c|c|c|c|c|}
\hline & 2001 & $\begin{array}{c}2002 \\
\text { Est. }\end{array}$ & $\begin{array}{c}2003 \\
\text { Est. }\end{array}$ & $\begin{array}{c}2004 \\
\text { Est. }\end{array}$ \\
\hline & \multicolumn{4}{|c|}{$\begin{array}{l}\text { (In millions of U.S. dollars, unless } \\
\text { otherwise indicated) }\end{array}$} \\
\hline \multicolumn{5}{|l|}{ External current account balance, excluding } \\
\hline official transfers & -165.0 & -113.6 & -139.7 & -185.2 \\
\hline Gross international reserves & 51.9 & 84.6 & 59.4 & 81.9 \\
\hline (in months of imports of goods and services) 5/ & 1.9 & 2.5 & 1.5 & 2.0 \\
\hline GDP (billions of leones) & $1,600.2$ & $1,965.2$ & $2,324.3$ & $2,854.5$ \\
\hline
\end{tabular}

Sources: Sierra Leonean authorities; and IMF staff estimates and projections.

$1 /$ Changes as a percentage of beginning-of-period money stock (including foreign currency deposits)

2/ Treasury bill rate (end of period); in percent.

3 / Net present value (NPV) of debt relative to backward-looking three-year average of exports of goods and services.

4/ Domestic revenue minus total expenditure and net lending, excluding interest payments, and externally financed capital expenditure and disarmament, demobilization, and reintegration (DDR) program.

$5 /$ In months of imports of goods and services of subsequent year. 
Press Release No. 04/238

International Monetary Fund

FOR IMMEDIATE RELEASE

Washington, D.C. 20431 USA

November 12, 2004

\author{
IMF Completes Fifth Review Under Sierra Leone's \\ PRGF Arrangement and Approves US\$21.1 Million Disbursement
}

The Executive Board of the International Monetary Fund (IMF) today completed the fifth review of Sierra Leone's performance under an SDR 130.8 million (about US\$197.6 million) Poverty Reduction and Growth Facility (PRGF) arrangement (see Press Release No. 01/39).

The completion of this review enables the release of an amount equivalent to SDR 14 million (about US\$21.1 million), which would bring the total amount drawn under the arrangement to SDR 116.8 million (about US\$176.5 million).

In completing the review, the Board waived the nonobservance of an end-March quantitative performance criterion and two structural performance criteria and approved an extension of the arrangement for a three-month period until June 25, 2004.

Following the Executive Board's discussion of Sierra Leone's economic performance, Rodrigo de Rato, Managing Director and Chair, made the following statement:

"Sierra Leone made further progress in 2004 toward completing the post-conflict transition, with the conclusion of the disarmament, demobilization, and reintegration exercise for over 72,000 former combatants.

"The broad-based economic recovery continued in 2003, as improved business confidence stimulated activity in the agriculture, mining, manufacturing, and services sectors. However, inflation increased sharply in 2003 and the first half of 2004, reflecting higher fuel costs, expansionary fiscal and monetary policies, and a depreciation of the currency.

"The authorities have made progress in implementing structural reforms. Fiscal and monetary policies in the first half of 2004 were weaker than envisaged, but corrective actions are being taken in the second half of the year. Shortfalls in external financing have also adversely affected program implementation in the first half of the year. The authorities are stepping up efforts to better monitor donor conditionalities in order to expedite disbursements.

“Given Sierra Leone's large reconstruction needs in the medium term and the heavy debt burden, domestic revenue mobilization will be important, including through tapping mineral revenues and strengthening tax administration. Expenditure will need to be better prioritized, in the 
context of poverty reduction efforts, and gradually reoriented toward investment. Better coordination with donors will help ensure more efficient fiscal management and the mobilization of increased resources for poverty reduction programs.

"To reduce inflation, monetary policy needs to be strengthened and complemented by prudent fiscal policy. The authorities are encouraged to be more proactive in containing the growth of private sector credit. This, together with strengthening of financial supervision and regulation, will also safeguard against a rise in nonperforming bank loans.

"The authorities have completed the first draft of a Poverty Reduction Strategy Paper (PRSP), in broad consultation with various sections of the society. The PRSP sets out a medium-term policy framework based on four pillars. These relate to governance, pro-poor sustainable growth, human development, and reduction of social vulnerabilities. The authorities need to clearly articulate the policy agenda that would emerge from the PRSP exercise, as this will help in securing, among other things, donor support.

"All non-Paris Club creditors have agreed to deliver debt relief, or indicated their willingness to do so. The authorities have also approached the World Bank for a debt buyback operation under the IDA facility, in order to continue addressing the problem of commercial debt arrears," Mr. de Rato said.

The PRGF is the IMF's concessional facility for low-income countries. PRGF-supported programs are based on country-owned poverty reduction strategies adopted in a participatory process involving civil society and development partners and articulated in a Poverty Reduction Strategy Paper (PRSP). This is intended to ensure that PRGF-supported programs are consistent with a comprehensive framework for macroeconomic, structural and social policies to foster growth and reduce poverty. PRGF loans carry an annual interest rate of 0.5 percent and are repayable over 10 years with a 5 1/2-year grace period on principal payments. 


\section{Statement by Peter J. Ngumbullu, Executive Director for Sierra Leone November 12, 2004}

\section{Introduction}

Sierra Leone has made important progress over the past one year to solidify its economic gains, maintain the peace, as well as develop a realistic and ambitious medium-term framework to guide economic policy-making. With success in the peace-keeping since 2000, prudent macroeconomic policy measures have been pursued by the authorities, including the implementation of wide-ranging reforms. Output has continued to expand rapidly during the period 2001-03, an indication of the gains realized from the resettlement of the population and increased activities in agriculture, mining, manufacturing and services. Other measures have been directed at reaching the country's full tax potential, which include those for the tapping of mineral revenues. Expenditures have been prioritized in the context of the PRSP objectives with a gradual reorientation towards financing investment. Better coordination procedures have also been pursued with donors, a process necessary for ensuring efficient fiscal management and for the mobilization of increased resources for poverty reduction. In addition, there is strong determination by the authorities to pursue the policy challenges of enhancing the investment climate, strengthening governance and transparency, as well as deepening of the financial sector.

\section{Recent Economic Developments}

The Sierra Leonean economy grew by 6.5 percent in 2003, reflecting robust operations in agriculture, mining, and manufacturing. Progress in enhancing domestic security and the success in maintaining political and economic stability have continued to bolster confidence. For 2004, real output is expected to grow at 7.4 percent, a little above the programme target. Increased emphasis has been placed on maintaining macroeconomic stability and reducing poverty. In addition, government has taken over responsibility from the UNAMSIL to maintain peace and security. This has resulted in major budgetary implications for security expenditures, given the need to equip and finance operations of the security agencies. The decentralization of public administration and related services to local authorities has also had fiscal implications, as all 19 councils would need to be initially assisted with administration and related costs. The higher fuel costs and delays in donor support have resulted in expansionary monetary policy and have also led to an increase in annual average inflation to 12 percent by end-June 2004 .

The authorities have directed their efforts at reducing the inflationary pressures through progressive implementation of fiscal and monetary tightening, and in addition have taken measures for further containment of domestic debt to achieve program targets and maintain debt sustainability, namely:

- The fiscal policy stance aims at supporting macroeconomic stability. The overall fiscal balance and domestic primary balance is expected to significantly improve in the second half of 2004, in reaction to implementation of measures that would lead to a reduction in domestic financing of the budget. 
- On monetary policy, given that broad money is projected to rise by 18 percent, the BSL has raised its statutory reserve requirement ratio from 10 to 12 percent to help contain money growth and mop up excess liquidity. In this regard, though reserve money is projected to grow by 6.5 percent in the second half of 2004, it will continue to be the primary intermediate monetary policy target.

- External sector policies are being directed at narrowing the current account deficit from its current level, projected at about 18 percent of GDP, which is 4.0 percentage points increase above the 2003 level, partly due to high oil prices and large import needs for the rehabilitation of the mining sector.

- As regards debt relief, my authorities have reached agreements with most official creditors and more effort is being made to conclude debt relief arrangements with commercial creditors. Upon reaching HIPC completion point, the authorities expect significant reduction in the NPV of debt to exports. As they continue to address the problem of commercial debt arrears, my authorities have requested the World Bank for assistance for a debt buyback operation under the IDA debt reduction facility.

\section{Progress Made on the Reform Agenda}

(i) On structural reforms, action has been taken to channel salary and other payments to teachers via the banking system, including raising the proportion of schools with bank accounts to 60 percent at end-December 2004, thereby facilitating greater use of banking services for payments to civil servants and teachers. Progress has also been made in completing benchmarks under the program, including hiring of professional and managerial staff in the Department of the Auditor General to expedite audits of government ministries and agencies. Employment ceilings have been established for schools and are now being published for enforcement. A monthly update of personnel data in the Establishment Secretary's Office has also been undertaken.

(ii) To sustain the gains made in revenue mobilization, the authorities have targeted fiscal incentives for tax collectors and have limited discretionary granting of tax exemptions to foreign investors. Sierra Leone has also joined the Extractive Industries Transparency Initiative (EITI) to ensure maximum transparency in the collection of revenues expected from the mineral sector.

(iii) In their determination to contain expenditures, the authorities have implemented measures to reduce noninterest outlays during the second half of the year. They will continue to prioritize expenditures in order to align them with available resources. Inspite of the above, poverty-related expenditures have been protected and the measures to contain expenditures will have minimal impact on the poor. Additional measures have also been implemented to avoid any accumulation of utility arrears by government ministries, departments and agencies. 
(iv) Financial sector reforms are being implemented by the BSL in order to enhance liquidity forecasting. The exchange rates continue to be based on weekly foreign exchange auctions. International reserves increased to two months of import cover, an increase of 0.5 months by end-2004. Progress has been made in strengthening both internal and external controls of the BSL, including taking additional steps towards implementation of the International Financial Reporting Standards.

(v) The authorities have also achieved significant progress in the preparation of a comprehensive mineral policy framework. Given the above developments and until the envisaged revisions to the legislative framework are finalized, the authorities will continue to consult with Fund staff in the context of the PRGF-supported program.

\section{Medium-Term Outlook and Challenges, 2005 - 2007}

The authorities are fully aware of the critical importance of sustaining high real growth as well as stable macroeconomic environment for tackling Sierra Leone's widespread poverty. The medium-term macroeconomic framework projects an annual growth of between 6 and 7 percent. Rising exports will continue to support high output growth during 2004-06, while higher growth in 2005 is expected to be led by the mineral sector. Agriculture, forestry and fishing, including services are expected to continue to be vibrant in the medium-term, a reflection of the favorable post-conflict environment. Inflation will be curtailed to single digits, and the current account balance, excluding official transfers, is expected to narrow from the current level of 31.3 percent of GDP to 10 percent by 2007. In this regard, the authorities would need more time to provide the necessary assurances and environment to encourage private investors, while moving towards a stable post-conflict situation.

Relevant policies that are needed to support key growth and poverty reduction objectives will continue to be pursued. The authorities are aware that sustained high growth requires substantial increases in domestic savings and investment, and as a result they will proceed with their objective to implement measures that would assist growth of community and microfinance institutions, in addition to liberalization measures that incorporates market-determined interest rates in the financial sector. They plan to contribute to this endeavor through budgetary savings, with the aim of ensuring substantial improvement in the domestic savings rate in the mediumterm within a range of 8-10 percent by 2006/07, far above the 2.0 percent realized during 2004 . Also, in this regard, the authorities intend to progressively raise the share of domestic investment through directing projected mineral revenues for this purpose.

\section{Fiscal policy}

The medium-term overall resource envelope would remain constrained. As a result, measures to strengthen tax administration, and enhancing domestic revenue collection would be undertaken, including broadening the tax base to tap mineral revenues and incorporate the informal sector. Possible amendments to the scope of income and corporate tax rate reductions are also under consideration. With the availability of technical assistance, sales of non performing public assets will be pursued to generate additional revenues that would facilitate financing of poverty programs and reduction of the domestic debt stock. 
Efforts will be strengthened to prioritize, rationalize and reduce expenditures to enable attainment of economic growth, as well as developmental and poverty-related objectives, in addition to the production of more efficient public service delivery at both central and local government levels. Mechanisms for monitoring implementation of donor conditionalities to ensure faster disbursement of donor resources will be strengthened, and the authorities are currently taking measures to plan their expenditures more cautiously taking into account assured availability of donor financing as well as revenues generated from domestic sources.

\section{Monetary and Exchange Rate policy}

Over the medium-term, the authorities intend to continue to maintain a floating exchange rate regime, free from restrictions and one that would ensure flexibility in response to external and internal shocks, and enable the parallel market spread to maintain its current low and broadly stable position. In addition, a major objective of the authorities will be to strengthen the external current account position, which, if led by strong export growth, could bring about an appreciation of the exchange rate over the medium-term. The monetary authorities will continue to increase external reserves to provide a cushion against external shocks.

\section{External Sector policy}

Over the medium-term, the authorities will work towards adopting common external tariff, a major objective aimed at consolidating the ECOWAS integration process. This measure is expected to reduce average tariff to 12 percent from the current high level of 17.5 percent, and would work to ensure achievement of benefits from the envisaged agreement on Economic Partnership with the European Union. More efforts will be made to take advantage of the opportunities available to the country from less export barriers in developed countries.

\section{Implementation of Further Reforms}

The authorities are giving specific attention to the implementation of recommendations of the financial audit of the Ministry of Education in line with the revised framework. The proposed amendments to the Income Tax, Sales Tax and Customs Acts with assistance of the CommonWealth Secretariat are expected to be finalized for implementation in early 2005. Efforts will also be made to finalize the new Procurement Act. Furthermore, the NRA will develop model agreements for the mineral sector in line with similar agreements in the petroleum sector. In addition, diagnostic studies and reforms which are funded by DfiD for six key ministries are to be conducted over the next three years.

\section{Poverty Reduction Strategy Process}

The authorities are working towards seeking external resources to ensure a realization of the MDGs. They intend to mobilize additional resources to facilitate funding for programs which are important in achieving human development goals by 2015. Given the efforts towards finalization of the full PRSP, appropriate policy frameworks will be instituted to safeguard macroeconomic stability in case of large increases in aid. 
In view of the relative importance of agriculture and rural development in promoting broad based growth and poverty reduction, the authorities will embark on a multi-pillar approach to raise agricultural output and productivity, promote large-scale commercial farming, and encourage crop diversification. The authorities recognize the importance of capacity building, improved infrastructure and support and extension services in these endeavours and are committed to providing them within the limitations of the budget and also seek technical assistance from the international community. They are also reviewing land legislation to develop an enabling environment for land utilization.

\section{Conclusion}

Although performance under the program at end-March has been mixed, the authorities have taken necessary measures to address the shortcomings and have been able to bring performance back on track during the second half of 2004, which is broadly in line with the original program. This is an indication of their strong commitment to the implementation of the program. To reverse the slippages that have occured, they have taken steps to reduce noninterest current expenditures in line with program targets; and have taken measures to deal with the slippages in the quantitative performance criteria for end-March on net bank credit to government; and have introduced new personnel management regulations for the civil service.

In this regard, and in line with the agreement reached with the staff mission, the authorities are committed to take measures to strengthen and consolidate the reform process, particularly in those areas where slippages have occurred. They will continue to take measures to reconcile the fiscal and monetary data for the period of 2000/02 and explore options to extend reserve requirements to foreign currency deposits of commercial banks. Implementation of securities repurchase agreements will commence following finalization of the necessary preparations. Given the existing capacity constraints in many areas, my authorities are seeking Fund technical assistance in the areas of fiscal and monetary operations, banking supervision, payment systems and liquidity forecasting. Furthermore, additional reforms in all the relevant areas are being proposed in the near-term to strengthen program implementation.

In the light of these strong commitments, my authorities are requesting a completion of the fifth review under the PRGF arrangement and an extension of the arrangement for a three-month period. The authorities have consented to the Fund's publication of the paper. 